\title{
Administrative Records and the Courts
}

\author{
Aram A. Gavoor* \& Steven A. Platt**
}

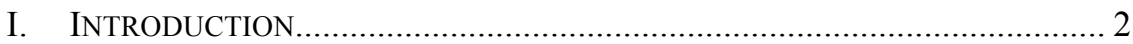

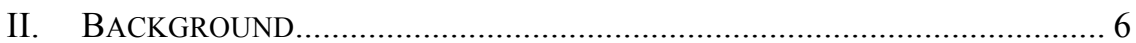

A. Agencies and Agency Actions ................................................... 6

B. Administrative Records, Generally .................................... 8

C. Compiling the Administrative Record for APA Litigation.... 11

D. The History of Judicial Review of Agency Action ................ 14

E. The Administrative Procedure Act.................................... 18

F. Supreme Court Treatment of the Record Rule..................... 21

III. HOW THE APA RECORD RULE SHOULD BE INTERPRETED IN

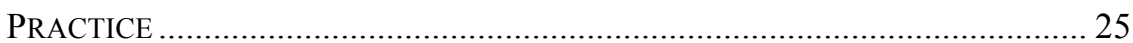

A. How a Limited Completion Interpretation of "the Whole Record" Comports with the APA......................................... 26

B. The Proper Means to Ensure the Court Reviews the Whole Record: Completion................................................... 31

C. What Does Not Belong in the Record.................................. 35

D. Supplementation Is an Improper Means of Inserting Documents into an APA Administrative Record.................. 42

E. How to Complete the Record................................................ 54

F. Remedies for Difficult Completion ...................................... 57

IV.HOW THE APA RECORD RULE IS BEING INCORRECTLY INTERPRETED BY SOME COURTS AND LITIGANTS ......................................... 62

A. Why Some APA Petitioners and Courts Are Not Following the Record Rule .................................................... 63

B. How Some APA Petitioners and Courts Are Not

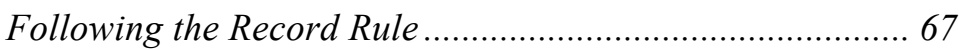

C. Negative Consequences of Misapplying the Record Rule ... 69

V. What Should Be Done to Stabilize THE SPaCE .75

\footnotetext{
* Visiting Associate Professor of Law, The George Washington University Law School. Thanks to Kristin Hickman, Richard Pierce, Orin Kerr and Andrew Kloster for their guidance and advice. ** J.D., University of Minnesota Law School, B.A., The University of Iowa.
} 


\section{INTRODUCTION}

In September 2017, the University of California Regents spearheaded a major programmatic challenge to a U.S. Department of Homeland Security initiative under the Administrative Procedure Act of 1946 (APA). ${ }^{1}$ Because the APA directs courts to review the legality of agency action upon "the whole record," ${ }^{2}$ the government filed what it deemed to be the complete administrative record of all non-deliberative documents considered by the agency when it undertook the challenged initiative. ${ }^{3}$ The plaintiffs responded by arguing the record was missing thousands of pages of documents. ${ }^{4}$ The plaintiffs moved the court to order the Department of Homeland Security to complete the administrative record. ${ }^{5}$

Just five weeks after the lawsuit was filed, a federal district judge granted the plaintiffs' motion. ${ }^{6}$ Despite later acknowledging that " $\left.t\right]$ he Supreme Court has never defined 'the whole record' in the context of informal agency action" - the kind of agency action at issue there - the judge found that the government did not file a complete record. ${ }^{8}$ The court gave the government a mere ten days to complete the record with, among other things, "all emails, letters, memoranda, notes, media items, opinions and other materials directly or indirectly considered in the final agency decision," including all materials considered by a cabinet secretary and anyone who gave the secretary written or oral input. ${ }^{9}$ The court of appeals agreed. ${ }^{10}$

But the proper scope of the record was an important enough issue that the U.S. Supreme Court weighed in with stunning alacrity-less than two months after the district court issued its order-deciding to stay the district court's order over a vigorous dissent regarding the proper composition of the administrative record. ${ }^{11}$ Shortly thereafter the Court granted

\footnotetext{
1. Regents of Univ. of Cal. v. U.S. Dep't of Homeland Sec., No. C 17-05211, 2017 WL 4642324 (N.D. Cal.), aff'd sub nom., In re United States, 875 F.3d 1200 (9th Cir.), rev'd, 138 S. Ct. 443 (2017); 5 U.S.C. $\S \S 550-709$ (2012).

2. 5 U.S.C. $\$ 706$.

3. Regents of Univ. of Cal., 2017 WL 4642324, at *1; 5 U.S.C. § 706.

4. Regents of Univ. of Cal., 2017 WL 4642324, at*1.

5. Id.

6. Id. at $* 8$.

7. Regents of Univ. of Cal. v. U.S. Dep't of Homeland Sec., No. C 17-05211, 2018 WL 1210551 , at $* 2$ (N.D. Cal. Mar. 8, 2018).

8. Regents of Univ. of Cal., 2017 WL 4642324, at *8.

9. Id. at *8-9.

10. In re United States, 875 F.3d 1200 (9th Cir. 2017).

11. In re United States, 138 S. Ct. 371 (2017); id. at 371-76 (Breyer, J., dissenting).
} 
a writ of certiorari and issued a decision. ${ }^{12}$ Although its opinion in In re United States did not ultimately resolve the question, the Court vacated the decision of the court of appeals and remanded the case for the district judge to resolve a threshold jurisdictional challenge before addressing record supplementation. ${ }^{13}$ Upon doing so, the district court again ordered supplementation of the administrative record in line with its interpretation of the APA, again acknowledging the lack of direct precedent. ${ }^{14}$ This case emblematizes broader judicial indeterminacy on what constitutes "the whole record" for purposes of APA administrative record review.

The scope and domain of the administrative record is critical to APA review because the record can have dispositive effects on litigation. In another example, when the U.S. Department of Defense awarded a government contract to Lockheed Martin Federal Healthcare to help service its health care program, an unsuccessful competing bidder, Axiom Resource Management, filed an APA lawsuit alleging the contracting officer acted arbitrarily or capriciously by failing to satisfactorily address a Lockheed conflict of interest. ${ }^{15}$ Moving to permanently enjoin the Department of Defense from awarding the contract to Lockheed, Axiom sought to supplement the agency record with affidavits that it had created for the litigation. ${ }^{16}$ The government objected on the ground that the APA limits the scope of judicial review to "the whole record"- the materials considered or relied upon by the agency. ${ }^{17}$

The judge dismissed those objections. "My practice... since I've been on the Court is to allow everybody to put ... whatever they want to put into the record in trial and even in an administrative record to supplement," she said. ${ }^{18}$ Her reasons seemed practical enough: "My own view is that I don't know what's important or not until I finally get around to looking at the record," and "[i]f it goes up on appeal, that way the Appellate Court has a full record to work with." 19 The judge promised that "[j]ust because it's in the record doesn't mean I'm going to rely on it for any reason," finding that this practice would not prejudice the

\footnotetext{
12. In re United States, 138 S. Ct. 443 (2017) (per curiam).

13. Id. at 445 .

14. Regents of Univ. of Cal. v. U.S. Dep't of Homeland Sec., No. C 17-05211, 2018 WL 1210551, at *2 (N.D. Cal. Mar. 8, 2018).

15. Axiom Res. Mgmt., Inc. v. United States, 564 F.3d 1374, 1377-78 (Fed. Cir. 2009).

16. Id. at 1378 .

17. Id. at 1379

18. Id. (alteration in original) (quoting a transcript of the district court judge's comments at a telephone conference with the parties).

19. Id.
} 
government. ${ }^{20}$ The court invited both sides to submit extra evidence and to not "hold back," urging a sense of perspective: "The world will not come to an end. Western civilization will not crumble based upon this value judgment." ${ }^{21}$ After evaluating newly added evidence, the judge granted Axiom's motion and permanently enjoined Lockheed from performing the contract. ${ }^{22}$

On appeal, the U.S. Court of Appeals for the Federal Circuit acknowledged the need for an adequate record during APA judicial review. ${ }^{23}$ However, the court emphasized that the relevant Supreme Court cases from the 1970s and 1980s limit review to the record actually before the agency, to "guard against courts using new evidence to convert the arbitrary and capricious standard into effectively de novo review." 24 The Federal Circuit concluded that the lower court had not made any determination that judicial review was hindered by a lack of evidence and that more evidence was necessary. ${ }^{25}$ Reproducing the judge's remarks about uncritical record supplementation, the court of appeals reversed the judge's decision as an abuse of discretion. ${ }^{26}$

These two anecdotal cases are representative of a larger problem within the bench and bar regarding what materials may be reviewed by a federal court when it engages in APA review of agency action. This Article examines the federal courts' varying views on the scope of administrative records for APA purposes. Although the APA is an omnibus waiver of sovereign immunity that facilitates the judicial review of thousands of executive branch actions, the statute provides a minimalist definition of the evidence that courts should consider in its scope of review provision: "the court shall review the whole record." 27 Juxtaposed against the breadth and prescriptive richness of other authorities that govern federal civil litigation such as the Federal Rules of Civil Procedure and Federal Rules of Appellate Procedure, the APA's evidentiary scheme is distinctly different. Taken with the APA's differing procedural requirements for various actions that are subject to judicial review, which in turn animates the positive or absence of positive requirements for administrative record content, the answer to what constitutes "the

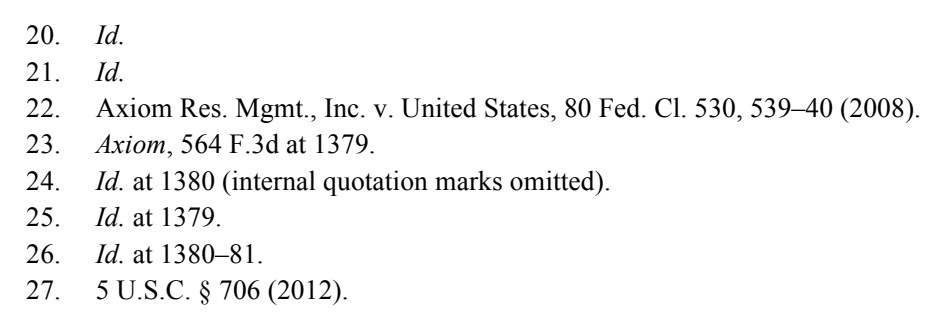


whole record" is highly reliant on case law.

This case law, however, has developed in the lower courts while the Supreme Court has not yet provided clarification or guidance. The principal case from which the Supreme Court's administrative record jurisprudence flows did not come until twenty-five years after the APA was enacted, in Citizens to Preserve Overton Park, Inc. v. Volpe. ${ }^{28}$ Although Overton Park has been cursorily validated by a few other Supreme Court cases since, the Supreme Court has not seriously grappled with the issue since $1990 .^{29}$ Recently, the Supreme Court gave litigants hope when it took up cases involving the scope of the APA record. But in 2017, the Supreme Court's In re United States decision did not address the issue despite a vigorous four-Justice dissent proposing to do so. ${ }^{30}$ Again in 2018, the Supreme Court, in a case about the Secretary of Commerce's decision to include a question about citizenship on the next decennial census, issued an order in the case but has thus far refrained from reaching the merits, thus showcasing the persistence of this unsettled issue. ${ }^{31}$

This Article argues that in the presence of ambiguous Supreme Court jurisprudence on the subject and the thirty-year absence of significant jurisprudence on administrative records, the lower courts' views on the definition of an administrative record are suffering from significant interdecisional inconsistency and varying correctness.

Part II of the Article surveys the historical practices of agencies in compiling, maintaining, and furnishing administrative records. It chronicles the federal courts' treatment of administrative records upon judicial review, both before and after the passage of the APA. It reviews the sparse Supreme Court case law addressing the topic, starting with Overton Park.

Part III analyzes the circumstances in which a party may add materials to the administrative record presented in federal court. Identifying the proper avenue as mere record completion-as opposed to record supplementation-Part III explains the basis for such a rule and why it is consistent with the APA's text, structure, and history, and all Supreme Court holdings and dicta on the topic. Part III then surveys the practical manner in which this process should proceed, by considering the litigants' perspective and the federal courts' local rules and practices.

\footnotetext{
28. 401 U.S. 402 (1971).

29. See Pension Benefit Guar. Corp. v. LTV Corp., 496 U.S. 633, 653-56 (1990).

30. See In re United States, 138 S. Ct. 371 (2017).

31. In re Dep't of Commerce, No. 18A375, 2018 WL 5259090 (U.S. Oct. 22, 2018). The research in this Article is current through October 29, 2018.
} 
Part IV observes how the APA record rule is interpreted in practice. It concludes that many advocates challenging informal adjudications and nonlegislative (or subregulatory) rulemaking are successfully putting before courts a judicial record that is broader than the relatively narrow administrative "record" contemplated by the statute and Overton Park. Part IV explains how the many court-made exceptions to the APA record rule are inconsistent with the correct interpretation detailed in Part III. Part IV argues that private litigants' successes advocating for judicial recognition of administrative records that are broader than that which is contemplated by the APA promotes gaps and pockets of error in the case law. Part IV hypothesizes how and why some members of the bench and bar misread the "whole record" requirement.

Part V explains why, despite those reasons in Part IV, judges and litigants should comport with the correct interpretation of the APA record rule discussed in this Article. This Part suggests mechanisms to normalize this rule and socialize parties to the correct operation of the APA and its record rule, including, for example, a recommendation for courts to adopt local rules to help to stabilize the space.

\section{BACKGROUND}

\section{A. Agencies and Agency Actions}

To appreciate the evidence necessary to review agency actions under the APA, it is helpful to understand the types of agency action that the statute empowers courts to review. The APA broadly affords judicial review to a "person suffering legal wrong because of agency action, or adversely affected or aggrieved by agency action within the meaning of a relevant statute." 32 An agency action cannot be reviewed until it is final. 33 "Agency action" is defined non-exhaustively to "include[] the whole or a part of an agency rule, order, license, sanction, relief, or the equivalent or denial thereof, or failure to act." 34

The APA establishes specific requirements for two primary types of agency action, rulemaking and adjudication. ${ }^{35}$ The APA recognizes both

\footnotetext{
32. 5 U.S.C. $\S 702$ (2012).

33. Id. $\$ 704$.

34. Id. $\S \S 701(\mathrm{~b})(2), 551(13)$.

35. See id. $\S \S 553-554$; Leland E. BeCK, Administrative CONFERENCE OF THE United

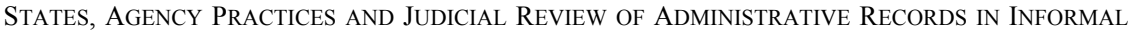
RULEMAKING 3 (2013) ("Case law on administrative records has not developed along discrete lines of 'rulemaking' or 'adjudication' or 'hybrid' proceedings, but more generally, and therefore cases that might appear to be technically applicable only under one statute are often applied to more gen-
} 
formal and informal rulemaking, although formal rulemaking has functionally been discontinued. ${ }^{36}$ Informal rulemaking subdivides into legislative and nonlegislative rulemaking. ${ }^{37}$ Legislative rules are official agency promulgations that have "the force and effect of law." ${ }^{38}$ Legislative rulemaking requires an agency to give the public notice of the proposed rulemaking and an opportunity to submit their views. ${ }^{39}$

Nonlegislative rules, in contrast, do not carry the force of law. ${ }^{40}$ Such rules include an agency's "interpretive rules," which announce how the agency has decided to interpret a statute or regulation. ${ }^{41}$ They also include subregulatory policy statements, which notify the public of the agency's current enforcement or regulatory priorities. ${ }^{42}$ And they include "rules of agency organization, procedure, [and] practice." 43

For formal adjudication, an agency must provide an oral evidentiary hearing and issue a decision that includes findings of fact and conclusions of law. ${ }^{44}$ The APA is silent on what, specifically, informal adjudication means or requires. Case law interpreting the APA holds that formal findings are not required, but an agency must have some sort of process or procedure in place that produces some type of contemporaneous evidence. $^{45}$

Finally, the APA definition of "agency action" includes the failure of an agency to act, thus agency "action" can also mean a finalized state of inaction. $^{46}$

erally on judicial review of agency action under the statute is governed by the APA.").

36. Aram A. Gavoor \& Daniel Miktus, Public Participation in Nonlegislative Rulemaking, 61 Vill. L. REV. 759,769 (2016) (citing United States v. Fla. E. Coast Ry. Co., 410 U.S. 224, 227-28 (1973)).

37. Id. at 770 (citing 5 U.S.C. $\$ 553(\mathrm{c})$ ).

38. Id. (citing William Funk, When is a "Rule" a Regulation? Marking a Clear Line Between Nonlegislative Rules and Legislative Rules, 54 ADMIN. L. REV. 659, 659 (2002)).

39. 5 U.S.C. $\S 553$ (b)-(c). The APA exempts certain subjects from these requirements, for example, legislative rules concerning "a military or foreign affairs function." Id. $\S 553(\mathrm{a})(1)$.

40. 5 U.S.C. $§ 553($ b)(A); Christensen v. Harris Cty., 529 U.S. 576, 587 (2000).

41. 5 U.S.C. $§ 553($ b)(A); Perez v. Mortg. Bankers Ass’n, 135 S. Ct. 1199, 1203 (2015); ToM C. Clark, Attorney General's Manual on the Administrative Procedure Act 30 n.3 (1947) [hereinafter ATTORNEY GENERAL's MANUAL] (defining these as "rules or statements issued by an agency to advise the public of the agency's construction of the statutes and rules which it administers").

42. 5 U.S.C. $§ 553($ b)(A); Lincoln v. Vigil, 508 U.S. 182, 197 (1993); ATTORNEY GENERAL'S MANUAL, supra note 41 (defining these as "statements issued by an agency to advise the public prospectively of the manner in which the agency proposes to exercise a discretionary power").

43. 5 U.S.C. $\S 553(\mathrm{~b})(\mathrm{A})$.

44. Id. $\S \S 554,556-557$; see id. $\S \S 558-59$.

45. Citizens to Pres. Overton Park, Inc. v. Volpe, 401 U.S. 402, 416-18 (1971), abrogated on other grounds by Califano v. Sanders, 430 U.S. 99 (1977).

46. 5 U.S.C. $§ 551(13)$; Coal. for Sustainable Res., Inc. v. U.S. Forest Serv., 259 F.3d 1244, 


\section{B. Administrative Records, Generally}

The federal adjudication and, to a lesser extent, rulemaking apparatus is enormous. By one estimate, adjudication is exercised by forty-eight executive agencies, ${ }^{47}$ using approximately 1,931 administrative law judges. ${ }^{48}$ The Social Security Administration alone has a 1.1-millioncase backlog. ${ }^{49}$ Regarding rulemaking, federal agencies issued 3,281 final rules in 2017 and 3,853 final rules in 2016-compared to a total of 329 bills and joint resolutions passed during the entire 114th Congress between January 2015 and January 2017..$^{50}$ By one estimate, twenty-six executive agencies promulgated an "economically significant rule" or "a rule through a process that included a formal hearing" between 1998 and $2013 .^{51}$ This process takes time; before promulgating a rule, an agency must undertake a rigorous analysis that includes, for example, identifying regulatory priorities and outlining a regulatory agenda. ${ }^{52}$

Agencies have had to defend their adjudication and rulemaking pro-

1251 (10th Cir. 2001).

47. David E. Lewis \& JenNifer L. Selin, Administrative Conference of the United States, Sourcebook OF United States ExeCutive Agencies 130-31 tbl.19 (2d prtg. 2013). This figure does not include "specific bureaus, offices, or divisions within departments or agencies authorized to adjudicate or employing administrative law judges." Id. at 131. These agencies are counted if: (1) their main authorizing statute includes provisions authorizing adjudication; (2) their main authorizing state includes reference to adjudicatory portion of the APA, i.e., § 554; (3) they employ administrative law judges, per the Association of ALJs; or (4) they employ administrative law judges, per Justice Breyer in Free Enterprise Fund v. Public Co. Accounting Oversight Bd., 561 U.S. 477, 542-43 (2010) (Breyer, J., dissenting).

48. Office of Personnel Mgmt., Federal Administrative Law Judges by agency and level (EHRI-SDM as of March 2017), https://www.opm.gov/services-for-agencies/administrative-lawjudges/\#url=ALJs-by-Agency [https://perma.cc/ADB3-3KGS] (last visited Oct. 10, 2018). This figure is up from approximately 1,584 administrative law judges in 2010, Free Enter. Fund, 561 U.S. at 542-43 (Breyer, J., dissenting), and 1,350 administrative law judges in 2004. Michael Asimow, The Spreading Umbrella: Extending the APA's Adjudication Provisions to All Evidentiary Hearings Required by Statute, 56 ADMIN. L. REv. 1003, 1005 (2004). The Office of Personnel Management's 1,931 figure is surely under-inclusive, however, as it does not appear to count the "approximately 350" immigration judges. U.S. Dep't of Justice, Office of the Chief Immigration Judge, https://www.justice.gov/eoir/office-of-the-chief-immigration-judge-bios [https://perma.cc/85GS8VKM] (last visited Oct. 10, 2018).

49. Social Sec. Admin., Office of the InSpector Gen., Audit Report: Factors Related to Decreased Administrative Law Judge Productivity 1 (2017). In 2016, the Social Security Administration had 1,654 administrative law judges who issued at least one disposition. Id. at 2 tbl.1.

50. OfFice of the Federal Register, Federal Register Documents Published 19762017, https://www.federalregister.gov/uploads/2018/03/docsPublished2017.pdf [https://perma.cc /3U4A-2SX5] (last visited July 16, 2018); Statistics and Historical Comparison, GovTrack, https://www.govtrack.us/congress/bills/statistics [https://perma.cc/6SBB-KGCW] (last visited Oct. 10, 2018).

51. LEWIS \& SELIN, supra note 47, at 132 tbl.20.

52. Exec. Order No. 12,866, 58 Fed. Reg. 51735 (Sept. 30, 1993). 
cesses and actions with increasing frequency. Lawsuits against federal agencies may be becoming more partisan as well. ${ }^{53}$

Once APA lawsuits are filed, a court reviews the final agency action under the statute's judicial review provisions, including 5 U.S.C. $§ 706$. That section provides the standards for upholding agency action, including the well-known arbitrary or capricious standard. ${ }^{54}$ In making those determinations, 5 U.S.C. $\S 706$ says, "the court shall review the whole record or those parts of it cited by a party." Article is what constitutes "the whole record."

Lawsuits against agencies revolve around the record that the agency created while completing the challenged action, for example, while adjudicating the dispute or making the rule at issue. Before going further, it bears emphasis that a "record" means different things in different contexts for an agency. This Article uses "administrative record" to mean "the whole record" upon which APA judicial review is founded. But agencies maintain, generate, collect, or preserve information for many purposes besides defensive litigation. An agency may maintain unofficial, uncoordinated, or ad hoc records as best practices or through the uncoordinated actions of their employees. Often, agencies develop relationships with records because of regulations or statutes. Agencies may do so to comply with the Federal Records Act, ${ }^{56}$ but many other laws

53. See, e.g., Paul Nolette, State attorneys general have taken off as a partisan force in national politics, WASH. POST (Oct. 23, 2017), https://www.washingtonpost.com/news/monkeycage/wp/2017/10/23/state-attorneys-general-have-taken-off-as-a-partisan-force-in-national-politics/? utm_term=.aa4109bfcb9c [https://perma.cc/XW3B-KUKC] (detailing the rise in litigation by state attorneys general against the federal government to challenge agency action); Neena Satija et al., Texas vs. the Feds-A Look at the Lawsuits, TEX. TRIB. (Jan. 17, 2017), https://www.texastribune.org/2017/01/17/texas-federal-government-lawsuits/ [https://perma.cc/ ER4Z-9DDD] (explaining that through nearly the end of Obama's second term, the State of Texas had sued his administration at least 48 times, "a point of pride for the state's Republican leaders"); Andrew Grossman, Regulation Through Sham Litigation: The Sue and Settle Phenomenon, HeRITAGE FOUND. (Feb. 25, 2014), https://www.heritage.org/crime-and-justice/report/regulation-throughsham-litigation-the-sue-and-settle-phenomenon [https://perma.cc/X4MW-3TVQ] (accusing the federal government of colluding with likeminded activist groups to be sued and then to settle on unaccountable terms); Gillian E. Metzger, Agencies, Polarization, and the States, 115 COLuM. L. Rev. $1739,1760 \&$ n. 105 (2015) (detailing Congress's increasing tendency to bring "high-profile lawsuits on party-line votes" and file "only partisan briefs").

54. 5 U.S.C. § 706(2)(A) (2012) (empowering a court to "hold unlawful and set aside agency action, findings, and conclusions found to be-(A) arbitrary, capricious, an abuse of discretion, or otherwise not in accordance with law").

55. Id. § 706 .

56. See Federal Records Act of 1950, 64 Stat. 583 (current version as amended at scattered of 44 U.S.C.); Harold J. Krent, Federal Agency Ombuds: The Costs, Benefits, and Countenance of Confidentiality, 52 ADMIN. L. REV. 17, 26 (2000) (describing the broad imposition on agencies to make and preserve "documents relating to all official agency functions bearing on the formulation of agency policy, the conduct of agency personnel, and the agency's impact on third parties"). APA 
may apply depending on the agency. These recordkeeping practices may or may not have incidental effect on the administrative record central to APA review. ${ }^{57}$

While performing agency actions, an agency may generate an administrative record totaling thousands of pages. ${ }^{58}$ To take one example, the Food and Drug Administration's record in one routine case was 133,000 pages, reflecting 48,000 rulemaking comments. ${ }^{59}$ A Supreme Court dissenting opinion recently acknowledged an administrative record that exceeded a million pages. ${ }^{60}$ Other records, however, had only 40,000 pages; ${ }^{61}$ another, a mere 761 pages. ${ }^{62}$ Conceivably, an administrative record could comprise only one page.

The contents of an administrative record derive mostly from outside sources. ${ }^{63}$ Sometimes, however, a record will contain research that the agencies conducted. ${ }^{64}$

record content might be at least a record under the Federal Records Act. The literature does not appear to have plumbed that question, which lies beyond the scope of this Article.

57. The Freedom of Information Act, 5 U.S.C. $§ 552$ (2012 \& Supp. 2017), the Privacy Act of 1974, 5 U.S.C. § 552a (2012 \& Supp. 2017), the Presidential Records Act (44 U.S.C. § 2201-2207 (2012 \& Supp. 2016)), and the Health Insurance Portability and Accountability Act of 1996, Pub. L. No. 104-191, 110 Stat. 1936 (codified as amended in scattered sections of 18, 26, 29 and 42 U.S.C.) all affect agency records, as do executive orders. E.g., Exec. Order No. 9,784, Providing for the More Efficient Use and for the Transfer and Other Disposition of Government Records, 11 Fed. Reg. 10909 (Sept. 25, 1946), revoked, 19 Fed. Reg. 5963 (Sept. 15, 1954).

58. Baltimore Gas \& Elec. Co. v. Nat. Res. Def. Council, Inc., 462 U.S. 87, 98 \& n.11 (1983) (describing the "sheer volume" of proceedings).

59. NVE Inc. v. Dep't of Health \& Human Servs., 436 F.3d 182, 188 (3d Cir. 2006).

60. In re United States, 138 S. Ct. 371, 374-75 (2017) (Breyer, J., dissenting from grant of stay) (citing Ga. ex rel. Olens v. McCarthy, 833 F.3d 1317, 1320 (11th Cir. 2016)).

61. New Jersey v. U.S. Army Corps of Eng'rs, Civil Action Nos. 09-5591, 2010 WL 2771771, at $* 4$ (D.N.J. July 13, 2010).

62. Supreme Foodservice GmbH v. United States, 109 Fed. Cl. 369, 379 (2013).

63. See 5 U.S.C. $\S \S 553$ (c) (2012) ("[T]he agency shall give interested persons an opportunity to participate in the rule making through submission of written data, views, or arguments ...."), 556(d) (giving parties in formal adjudications the opportunity to present witnesses and evidence); 42 U.S.C. $\$ 7607(\mathrm{~d})(2)-(6)$ (2012) (Clean Air Act provision requiring the EPA Administrator to "give interested persons an opportunity for the oral presentation of data, views, or arguments" when the EPA is promulgating a rule); 42 U.S.C. $\S 405$ (2012 \& Supp. 2017) (governing the receipt of evidence at Social Security Title II hearings); 22 C.F.R. § 51.71(d) (2018) (in a passport revocation hearing before the Department of State, permitting the revoked passport's bearer to offer evidence, present witnesses, and make arguments).

64. See Emily Hammond Meazell, Super Deference, the Science Obsession, and Judicial Review as Translation of Agency Science, 109 MicH. L. REV. 733, 746-47 (2011); Thomas O. McGarity, The Complementary Roles of Common Law Courts and Federal Agencies in Producing and Using Policy-Relevant Scientific Information, 37 ENVTL. L. 1027, 1028-29 (2007) ("The agencies have become repositories of huge amounts of scientific information that they may use in taking regulatory action or disseminate to the public by way of warnings or cautionary statements."). 


\section{Compiling the Administrative Record for APA Litigation}

When agency action is challenged in federal court, the administrative record will rarely already exist in a form ready to submit to the court. Few agencies compile records as they are developed; if it does, it is primarily for internal purposes or publication by a governmental third-party like the Federal Register. ${ }^{65}$ Because not every agency action is challenged in court, "[m]ost agencies develop a formal index only when necessary for internal or judicial purposes." commenced do agencies consciously search their systems and compile the relevant documents.

Regardless of whether litigation will certainly follow, agencies often maintain the documents that would be necessary to satisfy judicial review requirements. ${ }^{67}$ Record inputs are defined, to varying degrees of specificity, by statutes, ${ }^{68}$ regulations,${ }^{69}$ and case law. ${ }^{70}$ The APA is one such statute, although it is a procedural mandate and an omnibus waiver of sovereign immunity that may be supplanted by an agency's more specific organic statute. ${ }^{71}$ The APA presumes agencies will generate a record as they adjudicate or make rules, but the statute does not exhaustively define the procedures necessary to generate the record for all types of

\footnotetext{
65. See BECK, supra note 35 , at 46 .

66. Id.

67. Nicholas Bagley, Remedial Restraint in Administrative Law, 117 CoLUM. L. REV. 253,
} 261 (2017).

68. Substantive statutes include 16 U.S.C. § 1465(b)(2)-(3) (2012) (directing the Secretary of Commerce to close at a particular point the record in a Coastal Zone Management Act case and to not reopen it except under certain conditions) and 42 U.S.C. $§ 7607(d)(7)(A)(2012)$ (defining the record for judicial review in Clean Air Act claims). Procedural statutes include 28 U.S.C. § 2112(b) (2012) (requiring a record consisting of "the order sought to be reviewed or enforced, the findings or report upon which it is based, and the pleadings, evidence, and proceedings before the agency, board, commission, or officer concerned, or such portions thereof" for circuit court review of agency action); 15 U.S.C. $\$ 2060(\mathrm{~g})(2)(2012)$ (incorporating 28 U.S.C. $\$ 2112$ 's record filing requirements in judicial review of Consumer Product Safety Act claims); FED. R. APP. P. 16(a), 17(b) \& advisory committee's notes to 1967 adoption (incorporating 28 U.S.C. § 2112).

69. E.g., 40 C.F.R. $\S 300.810$ (2018) (listing certain documents that "typically" should and should not be included in CERCLA administrative records); Id. § 24.03(b) (2017) (same, for Solid Waste Disposal Act actions).

70. Compare, e.g., Ohio Valley Envtl. Coal. v. Whitman, No. Civ.A. 3:02-0059, 2003 WL 43377, at *5 (S.D.W. Va. Jan. 6, 2003) ("[T] he administrative rulemaking process is precisely one of initial proposals, comments, compromise, revisions, and final drafts, and the materials produced in this process are typically part of the administrative record."), with Seattle Audubon Soc. v. Lyons, 871 F. Supp. 1291, 1308-09 (W.D. Wash. 1994) (finding that the administrative record was "legally sufficient" even though "[t]housands of pages of notes, memoranda, and other working documents and electronic communications were destroyed"), aff'd sub nom., Seattle Audubon Soc. v. Moseley, 80 F.3d 1401 (9th Cir. 1996).

71. See 5 U.S.C. $\$ 702(2012)$. 
agency action.

To ascertain the necessary contents of an administrative record, the agency and the affected individuals must consult the relevant standard of review for the type of agency action at issue and the relevant provision of the APA that identifies procedures for what was challenged. ${ }^{72}$ Formal rulemaking challenges, which seldom arise following the decline of formal rulemaking in the 1970s, are reviewed on the "transcript of testimony and exhibits, together with all papers and requests filed in the proceeding." ${ }^{.73}$ The administrative record for formal rulemaking, then, must at a minimum include those materials. Similarly, informal rulemaking, both legislative and nonlegislative, will generally include the materials required for those types of agency action: notices pertaining to the rulemaking, transcripts of oral presentations made in the course of the rulemaking, and reports of any advisory committees. ${ }^{74}$

The formal adjudication record consists of the full hearing record, including prehearing conference agreements, official notice, and the decision by the administrative law judge. ${ }^{75}$ Informal adjudication is not explicitly covered by the APA. At minimum, informal adjudication records require notice of the denial and "a brief statement of the grounds for denial" required in adjudications. ${ }^{76}$ For an agency's failure to act, "because there is no final agency action to demarcate the limits of the record," judicial "review is not limited to the record as it existed at any single point in time." 77 Although the APA does not require particular documents to be created for informal adjudication or agency inaction, the general principles of "the whole record" discussed in this Article apply just as equally to informal adjudication and agency inaction as they do to

72. See id. § 553 (legislative informal rulemaking); §§ 554, 556-557 (formal adjudication), id. $\S \S 553,556-557$ (formal rulemaking, although this process has fallen into modern disuse). More generally, there are provisions like section 555(e), which promises affected individuals "[p]rompt notice" of, and the reasons for, any denial. See Olivares v. Transp. Sec. Admin., 819 F.3d 454, 46263 (D.C. Cir. 2016) (calling this a "fundamental' requirement of administrative law").

73. 5 U.S.C. § 556(e); United States v. Fla. E. Coast Ry. Co., 410 U.S. 224, $236-38$ (1973) (interpreting $\S \S 553,556$, and 557 of the APA to establish a high bar for when formal adjudication must occur: when an organic statute requires a hearing "on the record after opportunity for an agency hearing"); see also Richard E. Levy \& Sidney A. Shapiro, Administrative Procedure and the Decline of the Trial, 51 U. KAN. L. REV. 473, 484-87 (2003) (discussing three categories of APA rules and the demise of formal rulemaking).

74. See, e.g., Arkansas v. Zarb, No. 74-1186, 1975 WL 111, at *1 (D.D.C. July 31, 1975); Automo. Parts \& Accessories Ass'n v. Boyd, 407 F.2d 330, 338 (D.C. Cir. 1968); William F. Pedersen, Jr., Formal Records and Informal Rulemaking, 85 YALE L.J. 38, 64, 66-67, 79 (1975); BECK, supra note 35 , at 80 (recommending such as a best practice).

75. 5 U.S.C. $\S 556(\mathrm{e})$.

76. Id.

77. Friends of the Clearwater v. Dombeck, 222 F.3d 552, 560 (9th Cir. 2000). 
the other forms of agency action for which the APA establishes a documentary minimum for the record.

Because these materials are explicitly mentioned in the APA, they are, uncontroversial, the bare minimums the agency must produce as part of "the whole record." Beyond these basic parameters, different agencies have different policies on what should be maintained as an APA record. ${ }^{78}$ The U.S. Department of Justice, which is charged by statute with representing most federal agencies in court, ${ }^{79}$ has previously released guidance through its Environment and Natural Resources Division, ${ }^{80}$ which was mirrored by guidance released by the Executive Office for United States Attorneys. ${ }^{81}$ However, Department of Justice guidance to clients is exceptional to most agencies' administrative-record guidance because the Department of Justice lacks the power to act with the force of law in

78. See, e.g., BECK, supra note 35, at 27-28 (comparing recordkeeping policies of the Environmental Protection Agency with the Environmental and Natural Resources Division at the Department of Justice); Daniel J. Rohlf, Avoiding the 'Bare Record': Safeguarding Meaningful Judicial Review of Federal Agency Actions, 35 OHIO N.U. L. Rev. 575, 601 (2009) (detailing Department of the Interior guidance calling for "a designated agency employee . . . to maintain a contemporaneous 'Decision File' which contains 'the complete "story" of the agency decision-making process, including options considered and rejected by the agency"' (quoting U.S. DEP'T OF THE INTERIOR, STAND-

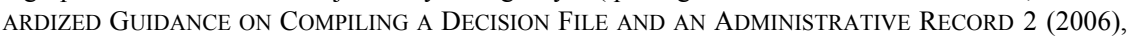
http://www.fws.gov/policy/e1282fw5.pdf [https://perma.cc/6EJG-A4FE])).

79. 28 U.S.C. $\S 516(2012) ; 5$ U.S.C. $\$ 3106$.

80. U.S. Dep't of Justice, Envt. \& Nat. Res. Div., Guidance to Federal AgenCies on COMPILING THE ADMINISTRATIVE RECORD 3 (1999), http://environment.transportation.org/ pdf/programs/usdoj_guidance_re_admin_record_prep.pdf [https://perma.cc/UDB8-KA6K] (advising agencies to maintain, in the administrative record, all records including those "the final decisionmaker did not actually review or know about"). However, the Department of Justice has since discounted this memo. See Federal Defendants' Memorandum of Points and Authorities in Opposition to Plaintiffs' Motion to Compel Completion of the Administrative Record and Production of a Privilege Log and for Leave to Conduct Third Party Discovery at 22-23, Inst. for Fisheries Res. v. Burwell, No. 16-cv-01574, 2017 WL 89003 (N.D. Cal. Jan. 10, 2017), ECF No. 79. Indeed, "the Department of Justice issued a memorandum, after the 1999 memorandum, stating that the Administrative Agency was in charge of their own administrative records and the material that would be included in the record." Coastal Conservation Ass'n v. Locke, No. 2:09-cv-641, 2010 WL 1439071, at *4 (M.D. Fla. Apr. 12, 2010); see U.S. DeP'T OF JuSTiCE, ENVTL. \& NAT. ReS. Div., MEMORANDUM (Dec. 23, 2008) (stating that deliberative process does not fall within the definition of an administrative record); U.S. DEP'T OF JUSTICE, ENVTL. \& NAT. RES. DiV., MEMORANDUM (Oct. 20, 2017) (same). Nevertheless, at least one court found this nonbinding guidance to be persuasive, and used the 1999 guidance against the government as a definition of what goes into the APA record. In re United States, 875 F.3d 1200, 1208 (9th Cir. 2017), cert. granted, vacated and remanded, 138 S. Ct. 443.

81. Joan Goldfrank, Guidance to Client Agencies on Compiling the Administrative Record, 48 U.S. ATTORNEYS' BULLETIN 7-9 (Feb. 2000) https://www.justice.gov/sites/default/files /usao/legacy/2006/06/30/usab4801.pdf [https://perma.cc/SS7F-XYMP] (identifying "general principles" of record compilation, which include suggestions that the agency include "policies, guidelines, directives, and manuals" and "all draft documents that were circulated for comment either outside the agency or outside the author's immediate office, if changes in these documents reflect significant input into the decision-making process."). 
this realm. This Department of Justice guidance is directed toward other agencies which the Department represents in federal litigation.

Reflecting the centrality of judicial review to agency operations, agencies - from the Environmental Protection Agency ${ }^{82}$ to the Department of Defense ${ }^{83}$ - have released memoranda to their employees offering suggestions on what should be preserved for the administrative record, either as the minimum required by law or, as a best practice, enough material to move beyond such minimums when they are hazy. This guidance helps sensitize employees to what confidential information they should fairly omit or redact. ${ }^{84}$

\section{The History of Judicial Review of Agency Action}

The text of the APA's "whole record" requirement, and the context of how agencies statutorily must undertake their actions, provides only the starting point for realizing the precise contours of the requirement. The complete meaning of that phrase is illuminated by the history of American administrative review and by the history of the APA in particular. Federal courts have a long tradition, predating the APA, of reviewing administrative records to assess the lawfulness of agency action. At the inception of the Republic, judicial review of agency action was not

82. U.S. EnVtl. Prot. Agency, Revised Guidance on Compiling Administrative ReCORDS FOR CERCLA RESPONSE ACTIONS 21-22 (Sept. 20, 2010), https://www.epa.gov/ sites/production/files/2013-11/documents/admin-record-mem-rev.pdf [https://perma.cc/53FQ-P9J3] (suggesting, for example, that copies of statutes and regulations should not be included in the record if they are publicly available but should be if they are not easily accessible); U.S. ENVTL. PROT. AGENCY, Final Guidance on Administrative Records for Selecting CERCLA Response Actions (Dec. 3, 1990), https://semspub.epa.gov/work/06/9335428.pdf [https://perma.cc/935Q-WXMG]; see also In re United States Dep't of Def. \& United States Envtl. Prot. Agency Final Rule, No. 15-3751, 2016 WL 5845712, at *2 (6th Cir. Oct. 4, 2016) (assessing a challenge to what materials properly belong in the record under the EPA's own internal guidance for what belongs in the administrative record).

83. U.S. DEP'T OF DEF., ESA IMPLEMENTATION: ADMINISTRATIVE RECORD, http://www.dodworkshops.org/Module_5_Administrative_Record_SMR_FINAL.pdf [https://perma .cc/9QZQ-F2NP] (last visited Oct. 12, 2018); see also, e.g., U.S. DEP'T OF THE INTERIOR supra note 78 (suggesting that the administrative record should "[c]ontain the complete 'story' of the agency decision-making process, including options considered and rejected by the agency"); NAT'L OCEANIC \& ATMOSPHERIC ADMin., NATIONAL OCEANIC AND ATMOSPHERIC ADMINISTRATION GUIDELINES FOR COMPILING AN ADMINISTRATIVE RECORD (Dec. 21, 2012), http://www.gc.noaa .gov/documents/2012/AR_Guidelines_122112-Final.pdf [https://perma.cc/J8GR-WH9D].

84. Because "the tradition that litigation is open to the public is of very long standing," Union Oil Co. of Cal. v. Leavell, 220 F.3d 562, 567 (7th Cir. 2000), courts have been critical of administrative records that are over-redacted. See, e.g., Brown \& Williamson Tobacco Corp. v. F.T.C., 710 F.2d 1165, 1176 (6th Cir. 1983) (reversing district court opinion ordering the administrative record to be sealed, because it "erred by failing to state findings or conclusions which justify nondisclosure to the public"); id. at 1180 ("We decline to carve out an exception to the right of access in order to protect the secrecy of an administrative record."). 
consistently available because of sovereign immunity ${ }^{85}$ An individual aggrieved by agency action had a few options, each with its own limitations. He or she could sue the executive official in the official's individual capacity on a theory that the official was acting ultra vires, as happened in Marbury v. Madison. ${ }^{86}$ A person could bring an equitable action to obtain an injunction against an agency. ${ }^{87}$ An individual could also sue the agency under state tort law. ${ }^{88}$ Although Congress had previously waived sovereign immunity in some narrow contexts, not until the APA was much more government action-particularly non-ultra vires government action - made reviewable by the judiciary. ${ }^{89}$

And throughout American history, people have had agencies to sue. Congress created the first federal agency, the Department of Foreign Affairs, in $1789 .{ }^{90}$ Other executive departments, such as the Department of the Treasury, ${ }^{91}$ followed not long after. But agencies did not begin to proliferate until around the Civil War. In the mid-nineteenth century, Congress created one of the first regulatory agencies in response to fatal steamboat explosions. ${ }^{92}$ That body, the Board of Supervising Inspectors,

85. See Alden v. Maine, 527 U.S. 706, 715 (1999) ("When the Constitution was ratified, it was well established in English law that the Crown could not be sued without consent in its own courts."). Thus, federal courts lacked jurisdiction over a particular claim unless Congress waived the federal government's sovereign immunity as to that claim. United States v. Mitchell, 445 U.S. 535, 538 (1980).

86. Marbury v. Madison, 5 U.S. (1 Cranch) 137, 151-52 (1803); Silvia L. Serpe, Note, Reviewability of Environmental Impact Statements on Legislative Proposals after Franklin v. Massachusetts, 80 CORNELl L. REV. 413, 437 (1995) ("As early as Marbury v. Madison, the Supreme Court established that an aggrieved party could seek remedy through a writ of mandamus to compel compliance with statutory mandates.") (citation omitted).

87. John F. Duffy, Administrative Common Law in Judicial Review, 77 TEX. L. REV. 113, 122 \& n.42 (1998) (citing Noble v. Union River Logging R.R., 147 U.S. 165, 170-71 (1893)). This was possible because "[a]t that time, federal equity law was judge-made." Id. at 121-22. "[Noble], however, was less significant because the Court relied on its mandamus precedents, which permitted a court to order performance of only ministerial duties." Id. at 122 n.42.

88. Id. at 122 \& n.43 (citing United States v. Lee, 106 U.S. 196 (1882)) (reviewing a challenge to agency action based on common-law ejectment).

89. Jonathan R. Siegel, Suing the President: Nonstatutory Review Revisited, 97 CoLUM. L. REV. 1612, 1622-37 (1997); Gregory C. Sisk, The Tapestry Unravels: Statutory Waivers of Sovereign Immunity and Money Claims Against the United States, 71 GEO. WASH. L. REV. 602, 616-17 (2003).

90. An Act for Establishing an Executive Department, to Be Denominated the Department of Foreign Affairs, ch. 4, § 1, 1 Stat. 28, 28-29 (1789) ("There shall be an [e]xecutive department, to be denominated the Department of Foreign Affairs ..."). The name was later changed to the Department of State. An Act to Provide for the Safe-Keeping of the Acts, Records and Seal of the United States, and for Other Purposes, ch. 14, § 1, 1 Stat. 68, 68 (Sept. 15, 1789).

91. An Act to Establish The Treasury Department, ch. 12, § 1, 1 Stat. 65, 65 (1780) ("[T]here shall be a Department of Treasury ....”).

92. Jerry L. Mashaw, Administration and “The Democracy": Administrative Law from Jackson to Lincoln, 1829-1861, 117 YALE L.J. 1568, 1630 (2008). 
had the power to make rules regarding boilers and boiler operators. ${ }^{93}$

The most well-known of the late-nineteenth-century agencies is the Interstate Commerce Commission, created in 1887. Its organic statute, the Commerce Act, provided for comparatively robust judicial review of factual findings. ${ }^{94}$ This tight control of agency action given by Congress to the courts became common during the late nineteenth century, as more agencies were created through statutes permitting de novo reconsideration of agency action. ${ }^{95}$

In March 1896, in what appears to be the first Supreme Court opinion to mention the scope of the administrative record on judicial review, the Court implied a note of caution about this congressionally-created relationship between courts and agencies. ${ }^{96}$ The Court observed how petitioners could obstruct an agency's mission by "withhold[ing] the larger part of their evidence from the commission, and first adduc[ing] it in the circuit court." 97 This passage, however, does not really reveal early judicial attitudes about administrative record review. The language was dicta, as this case was not focused on the administrative record, and the Court declined in the opinion to create a generally applicable APA-like record rule. ${ }^{98}$ It is also difficult to say whether the Court's observations applied to agencies generally or the Interstate Commerce Commission specifically. The Court noted the limited powers possessed by that agency; for example, the agency's factual findings were only "regarded as prima facie evidence." 99 In short, what the courts were doing may have

93. Id. at 1637-43 (2008) (citing the Steamboat Act of 1852, ch. 106, 10 Stat. 61). In the five years after the Act's passage, "deaths had fallen by a factor of five," a total of 1,226 lives. Id. at 1659.

94. Interstate Commerce Act of 1887 , ch. 104, § 16, 24 Stat. 379, 384-85 (If a common carrier violates the Act or disobeys an order of the Commissioner, the Commission or an aggrieved party may "apply, in a summary way, by petition, to the circuit court of the United States sitting in equity" which "shall have power to hear and determine the matter; ... on such hearing the report of said Commission shall be prima facie evidence of the matters therein stated ...").

95. Robert L. Rabin, Federal Regulation in Historical Perspective, 38 StAN. L. ReV. 1189, 1194, 1210-11 (1986) (citing Chi., Milwaukee \& St. Paul Ry. v. Minn. ex rel. R.R. \& Warehouse Comm'n, 134 U.S. 418 (1889)) (engaging in de novo review of the reasonableness of railroad rates established by the Interstate Commerce Commission).

96. Cincinnati, New Orleans \& Tex. Pac. Ry. Co. v. Interstate Commerce Comm'n, 162 U.S. 184, 196 (1896) (deeming this case a "proper occasion to express disapproval" of the petitioners' method of creating a fuller record in the courts than before the agency).

97. Id.

98. Id. ("We do not mean, of course, that either party, in a trial in the court, is to be restricted to the evidence that was before the commission ....").

99. Id. This same point applies to the very first case reviewing an ICC order, from a circuit court seven years earlier. Ky. \& I. Bridge Co. v. Louisville \& N.R. Co., 37 F. 567, 613 (C.C.D. Ky. 1889) ("[The ICC] is neither a federal court under the constitution, nor does it exercise judicial powers, nor do its conclusions possess the efficacy of judicial proceedings."). 
been more tied to the organic statutes than any particular philosophy on record review of agency action.

After the New Deal era, the judicial-scrutiny pendulum swung the other way. By 1930, Congress had created about two-thirds of the federal agencies that exist today. ${ }^{100}$ The courts began giving agency actions "considerable finality, and especially with respect to fact finding," as a measure of judicial restraint and in practical recognition of the difficulty in giving searching review to the multiplying number of agencies and the multiplying number and types of tasks they were performing. ${ }^{101}$ The Court's first recognition of the record rule, around this time in 1930, expressed respect for the efficiencies and comparative advantages of the agency whose action was under review, again the Interstate Commerce Commission. ${ }^{102}$ The result was "a strongly deferential model of review." 103

To ensure the fairness of the administrative state, the Franklin D. Roosevelt Administration, Congress, and some scholars began investigating how to streamline and improve how agencies operate. ${ }^{104}$ By 1933, the American Bar Association suggested legislation that would have returned to the model of more scrutinizing judicial review, with which many other contemporary proposals generally agreed. ${ }^{105}$ President Roo-

100. Gavoor \& Miktus, supra note 36, at 765 .

101. Wong Yang Sung v. McGrath, 339 U.S. 33, 36-37 (1950), superseded by statute, Supplemental Appropriation Act of 1951, Pub. L. No. 81-843, 64 Stat. 1044, 1048, as recognized in Ardestani v. I.N.S., 502 U.S. 129, 133 (1991).

102. As the Supreme Court wrote:

A proceeding under section 316 of the Packers and Stockyards Act is a judicial review, not a trial de novo. The validity of an order of the Secretary, like that of an order of the Interstate Commerce Commission, must be determined upon the record of the proceedings before him - save as there may be an exception of issues presenting claims of constitutional right, a matter which need not be considered or decided now.... To allow his findings to be attacked or supported in court by new evidence would substitute the court for the administrative tribunal as the rate making body. Where it is believed that the Secretary erred in his findings because important evidence was not brought to his attention, the appropriate remedy is to apply for a rehearing before him or to institute new proceedings. He has the power and the duty to modify his order, if new evidence warrants the change.

Tagg Bros. \& Moorhead v. United States, 280 U.S. 420, $443-45$ (1930).

103. Rabin, supra note 95, at 1194.

104. See McGrath, 339 U.S. at 37-38 (citing S. 5154, 70th Cong. (2d Sess. 1929)); John Yoo, Franklin Roosevelt and Presidential Power, 21 CHAP. L. ReV. 205, 228-31 (2018); Rabin, supra note 95, at 1265. See generally Walter Gellhorn, The Administrative Procedure Act: The Beginnings, 72 VA. L. REV. 219 (1986) (recounting the origins of the APA).

105. As one scholar described it:

During the Roosevelt Administration, many, including the American Bar Association, forcefully resisted increased agency reliance on informal decisionmaking processes, such as rulemaking, favoring instead formal adjudication processes. In fact, in 1940 the Act's 
sevelt asked the Attorney General to form a committee "to review the entire administrative process in the various departments of the executive Government and to recommend improvements, including the suggestion of any needed legislation."106 With the help of that committee, after World War II, Congress decided to pass administrative reform with less searching judicial review of agency action. ${ }^{107}$ Although an early iteration, the Walter-Logan Bill, was vetoed, the Administrative Procedure Act finally passed Congress without opposition and was signed by President Truman on June 11, $1946 .{ }^{108}$

\section{E. The Administrative Procedure Act}

The APA was designed "to introduce greater uniformity of procedure and standardization of administrative practice among the diverse agencies whose customs had departed widely from each other."109 With the APA, Congress established procedures by which the executive branch agencies conduct their business - and created a key check on final agency action, unreasonably delayed action, and agency inaction, in the form of judicial review broader than what had been historically available. The APA makes agency actions presumptively reviewable, a departure from the earlier era in which it was much more difficult for individuals to obtain redress for agency wrongs. ${ }^{110}$ Agency action now is unreviewable only if Congress has precluded review by statute or by conferral of discretion. ${ }^{111}$

main competitor, the Walter-Logan Bill, which provided for the elimination of agencies' informal rulemaking powers and required instead court-centered adjudication, passed both houses of Congress, only to be vetoed by a president who deemed the bill to be the work of lawyers "who desire to have all processes of government conducted through lawsuits." Eventually, the APA passed both the Senate and the House without a single vote against it in either chamber. Congress then designated the Attorney General's report as the Act's official legislative history. That report had set the stage for the passage of the Act by explaining the problems associated with agencies' decisionmaking procedures as of that time, making recommendations for a comprehensive and uniform approach to agency decisionmaking, and explaining how such an approach would remedy existing ills—almost serving as the Act's Federalist, one might say.

Steven P. Croley, The Administrative Procedure Act and Regulatory Reform: A Reconciliation, 10 ADMIN. L.J. AM. U. 35, 38-39 (1996) (footnotes omitted).

106. McGrath, 339 U.S. at 38-39.

107. Gavoor \& Miktus, supra note 36 , at 766-67.

108. McGrath, 339 U.S. at 39-40.

109. Id. at 41 .

110. Abbott Labs. v. Gardner, 387 U.S. 136, 140-41 (1967); see Gardner v. Toilet Goods Ass'n, 387 U.S. 167, 168 (1967); cf. Heckler v. Chaney, 470 U.S. 821, 837-38 (1985) (discussing discretionary action as an exception to the presumption in favor of judicial review of agency action).

111. 5 U.S.C. $\S 701(\mathrm{a})(1)-(2)(2012)$. 
Relevant here, the APA created a record rule, which limits judicial review to the administrative record before the agency when it made its decision. Congress did not explicitly pronounce this rule when it passed the APA, but the record rule derives from several sound sources. Section 10(e) of the APA, now codified at 5 U.S.C. $\S 706$, sets the textual lodestar for the record rule: "the court shall review the whole record or those parts of it cited by a party." 112 Though indirect, 5 U.S.C. $\S 706$ implies both a maximum of what will be reviewed - "the whole record"-and a minimum - "those parts of it cited by a party."113 The phrase "the whole record" is also used in reference to setting aside agency "action, findings, and conclusions," which implies the record is created and used by the agency and is the basis for its action, findings, or conclusions. ${ }^{114}$ Read in conjunction with the APA provisions that enumerate specific procedures that would generate contents of the record, and with similar organic statutes, "the whole record" appears to incorporate those materials. ${ }^{115}$ Importantly, although the record rule arises from 5 U.S.C. $\S 706$, it is separate from the merits standards found in that same section, which appear in enumerated paragraphs preceding the record rule's flush text.

The APA's legislative history, though inconclusive, lends further support to this reading. The legislative history of the APA is found largely in the Senate Judiciary Committee Report and, to the extent it is consistent with that report, in the Attorney General's Manual on the Administrative Procedure Act. ${ }^{116}$ Both documents have been found to be authoritative sources on the APA's meaning by the U.S. Supreme Court. ${ }^{117}$ Neither those sources nor other sources of legislative history,

112. 5 U.S.C. $\S 706$.

113. Id. The Solicitor General of the United States has acknowledged that "[t]he "whole record' provision thus does not speak to what materials that an agency must include in the record in the first place ...." Reply Brief for the Petitioners at 3, In re United States, 138 S. Ct. 443 (2017) (No. 17-801).

114. 5 U.S.C. $\S 706(2)$.

115. See 5 U.S.C. $\S \S 553-557$; Brian S. Prestes, Remanding Without Vacating Agency Action, 32 Seton Hall L. REV. 108, 126 n.120 (2001) (suggesting the agency statement of basis and purpose mandated for rulemaking by 5 U.S.C. $\S 553$ (c) belongs in "the whole record").

116. See S. REP. NO. 79-752 (1945); ATTORNEY GENERAL's MANUAL, supra note 40.

117. The Senate Judiciary Committee Report is authoritative to the extent that it does not vary from the APA, and Attorney General's Manual on the APA. See Chrysler Corp. v. Brown, 441 U.S. 281, 302 n.31 (1979) (citing the Senate Report as an "authoritative source[]" in interpreting the APA); Vt. Yankee Nuclear Power Corp. v. Nat. Res. Def. Council, Inc., 435 U.S. 519, 546 (1978). The Attorney General's Manual on the APA is authoritative to the extent it does not vary with the APA or the Senate Judiciary Committee Report. Chrysler Corp., 441 U.S. at 302 n.31 ("In prior cases, we have given some weight to the Attorney General's Manual ... since the Justice Department was heavily involved in the legislative process that resulted in the Act's enactment in 1946."); Bowen v. Georgetown Univ. Hosp., 488 U.S. 204, 218 (1988) (Scalia, J., concurring) ("[W]e have repeatedly given great weight" to "the Government's own most authoritative interpretation of the 
unfortunately, expound the term "the whole record,"118 excepting a statement in the Senate Judiciary Committee Report that "[t]he requirement of review upon 'the whole record' means that courts may not look only to the case presented by one party, since other evidence may weaken or even indisputably destroy that case." ${ }^{119}$ Otherwise, regarding the 5 U.S.C. $§ 706$ tailpiece containing the phrase "whole record," the Attorney General's Manual simply says that "[ $t]$ he provisions of section [706] constitute a general restatement of the principles of judicial review embodied in many statutes and judicial decisions." 120 Given the various and agency-specific attitudes toward administrative records that predated the APA, these statements provide little help in ascertaining what the APA demands of agencies for judicial review.

The APA's drafters may have addressed the issue so briefly because when Congress enacted the APA in 1946, the requirements for standing were stricter. ${ }^{121}$ Congress may not have anticipated the volume of private litigants that would invoke the APA to sue federal agencies, or have predicted that informal adjudication in particular - a category of agency action for which the APA does not outline record-generating procedures - would be so popular. But more importantly, the APA was intentionally not comprehensive. The APA's stated purpose was to be " $a$ bill of rights for the hundreds of thousands of Americans whose affairs are controlled or regulated in one way or another by agencies of the Federal Government." Among other advantages, this breathing room helps al-

APA, the 1947 Attorney General's Manual on the Administrative Procedure Act[.]").

118. BECK, supra note 35, at 2 .

119. S. Rep. No. 79-752, at 214.

120. ATTORNEY GeNERAL's MANUAL, supra note 41, at 93; see id. at 138 (stating that 5 U.S.C. $\S 706$ "declares the existing law concerning the scope of judicial review").

121. See Cass R. Sunstein, Standing and the Privatization of Public Law, 88 Colum. L. Rev. 1432, 1434-47 (1988) ("[T]he Court [in Association of Data Processing Service Organizations v. Camp, 397 U.S. 150 (1970)] moved dramatically in the direction of a standing doctrine that no longer owed its shape to common-law categories, or distinguished between the rights of regulated entities and regulatory beneficiaries."); Gordon G. Young, Judicial Review of Informal Agency Action on the Fiftieth Anniversary of the APA: The Alleged Demise and Actual Status of Overton Park's Requirement of Judicial Review "On the Record", 10 ADMIN. L.J. AM. U. 179, 201 n.81 (1996) ("It was not until [Data Processing] that the APA was read as presuming that anyone whose interest was arguably among the zone of interests specially protected by a statute would have standing to sue." (citations omitted)).

122. S. Doc. No. 79-248, at 298 (1946) (emphasis added), cited in, e.g., Diebold v. United States, 947 F.2d 787, 795 (6th Cir. 1991); see also S. Doc. No. 248 at 304 ("[The APA bill] is not a codification of administrative law. It represents, instead, an outline of minimum basic essentials, framed out of long consideration ...."); Antonin Scalia, Vermont Yankee: The APA, the D.C. Circuit, and the Supreme Court, 1978 Sup. Ct. Rev. 345, 363 (1978) ("[I]n 1973, with the Florida East Coast case, it became obvious even to the obtuse[] that the Supreme Court regarded the APA as a sort of superstatute, or subconstitution, in the field of administrative process: a basic framework that 
leviate constitutional concerns. ${ }^{123}$ So even if Congress did foresee issues defining "the whole record," it may have intended to leave the term indistinct for the courts to refine and apply. ${ }^{124}$

\section{F. Supreme Court Treatment of the Record Rule}

The capacious words "the whole record" have not been circumscribed by the U.S. Supreme Court, which has given this issue only indirect and muddled treatment. The seminal Supreme Court treatment of the record rule is arguably 1971's Citizens to Preserve Overton Park v. Volpe. ${ }^{125}$ There, citizens of Memphis sued the Secretary of Transportation, challenging his decision to build an interstate highway through a park. ${ }^{126}$ The only evidence in the judicial record that supported the Secretary's decision was affidavits that he submitted after litigation commenced. ${ }^{127}$ The Court held that this was insufficient, as a contemporaneous record is necessary to evaluate the propriety of the agency's actions. ${ }^{128}$ The Court remanded to the district court to discern the Secretary's reasoning at the time, through the consideration of either contemporaneous documents or documents created after the fact that shed light on the decision-making process at the time. ${ }^{129}$ The Court encouraged the lower courts to further remand to the agency to produce an acceptable record, but suggested the lower courts could, if truly necessary, fact-find themselves. ${ }^{130}$

Overton Park offers a few lessons on the record rule, although they

was not lightly to be supplanted or embellished, not even by other legislative enactments, much less by a continually evolving judge-made common law not based upon constitutional prescriptions or rooted in the language of the APA itself."); Croley, supra note 105 (likening the APA to a foundational document like the Constitution, the meaning and scope of which evolve over time).

123. See, e.g., Franklin v. Massachusetts, 505 U.S. 788, 799 (1992); Vt. Yankee Nuclear Power Corp. v. Nat. Res. Def. Council, Inc., 435 U.S. 519, 542 (1978) (suggesting that in quasi-judicial rulemaking determinations featuring a "very small number of persons" who are "exceptionally affected," additional procedures may be needed to satisfy due process).

124. See Thomas W. Merrill, Capture Theory and the Courts: 1967-1983, 72 CHI.-KenT L. REV. 1039, 1039 (1997) ("The [APA] is a framework statute, not a complete code. Its central provisions are rather sparse, and a number of important questions are not covered at all. It comes as no surprise, therefore, that the judicial gloss on the APA has taken on a large significance over time.").

125. 401 U.S. 402 (1971), abrogated on other grounds by Califano v. Sanders, 430 U.S. 99 (1977).

126. Id. at 406 .

127. Id. at 409 .

128. Id. ("We agree that formal findings were not required. But we do not believe that in this case judicial review based solely on litigation affidavits was adequate.").

129. Id. at 420 .

130. Id. 
are complicated by conclusory and unelaborated dicta. ${ }^{131}$ Justice Thurgood Marshall's opinion declared a need for "the full administrative record that was before the [agency] at the time [it] made [its] decision." The decision emphasized that unless required by the APA or another statute, however, formal findings were unnecessary. ${ }^{133}$ The "full administrative record that was before the Secretary at the time he made his decision," and only that record, is what could be reviewed. ${ }^{134}$ However, the Court created an exception to that rule that was neither presented by the facts of the case nor briefed by the parties. ${ }^{135}$ The Court stated that a petitioner can avoid the record rule's limitations upon a "strong showing of bad faith or improper behavior," though the Court did not explain what would rise to that level. ${ }^{136}$

The Court ruled against the Secretary of Transportation because the "bare record" he presented obstructed judicial review. ${ }^{137}$ By remanding for an examination of what the record should be, the Court cast the problem as a record problem, not a merits problem. The opinion, in announcing its remedy, permitted certain traditional civil discovery to fill gaps, but admonished that the preferred approach is to remand further to the agency for an explanation.

Some literature has criticized Overton Park for being inconsistent with the APA. ${ }^{138}$ Notwithstanding, Overton Park remains good, if sometimes cryptic, law. Two years later, the Supreme Court in Camp v. Pitts reiterated that "the focal point for judicial review should be the administrative record already in existence, not some new record made initially in

131. See, e.g., In re United States, 138 S. Ct. 371, 373-74 (2017) (Breyer, J., dissenting from grant of stay) (arguing that when Overton Park stated that it would accept the record presented by the agency, it really meant the record presented by the agency proceedings, thus the court, not the agency, was the ultimate arbiter of the record's contents), vacated and remanded, $138 \mathrm{~S}$. Ct. 44, rev'g 875 F.3d 1200 (9th Cir. 2017).

132. Overton Park, 401 U.S. at 420.

133. Id. at 417.

134. Id. at 420.

135. See id.; Brief for Petitioners at 28, Overton Park, 401 U.S. 402 (No. 1066); Brief for Respondents at 28, Overton Park, 401 U.S. 402 (No. 1066) (raising the idea and citing lower-court case law but emphasizing that "there has been no suggestion by petitioners in this case that [the decisionmakers] acted in bad faith, or as a result of political pressure, or because of some other improper or illegal reason prejudicial to petitioners"); Reply Brief for Petitioners, Overton Park, 401 U.S. 402 (No. 1066) (not addressing the topic).

136. Overton Park, 401 U.S. at 420.

137. Id.

138. E.g., Nathaniel L. Nathanson, Probing the Mind of the Administrator: Hearing Variations and Standards of Judicial Review Under the Administrative Procedure Act and Other Federal Statutes, 75 COLUM. L. REv. 721, 767-68 (1975) (arguing that the Overton Park outcome was a "distortion[] of the original meaning of the APA"). 
the reviewing court."139 Camp spoke to the remedy for a record-rule violation: if there was no "contemporaneous explanation of the agency decision," then the courts should remand to the agency. ${ }^{140}$

The Supreme Court indirectly addressed the record rule in Vermont Yankee Nuclear Power Corp. v. Natural Resources Defense Council, Inc., holding that courts cannot add to the procedures set by the APA, the organic statute, and the Constitution. ${ }^{141}$ The Court emphasized that agencies need flexibility to "permit[] them to discharge their multitudinous duties." 142 Thus, courts cannot impose their own notion of what are the best ways for agencies to execute their missions.

The Court returned to the remedy issue in 1985 in Florida Power \& Light Co. v. Lorion, where it emphasized that if the agency's action is unsupported by the record, then the remedy is remand to the agency "except in rare circumstances." such a circumstance. Lorion reeled back Overton Park's implication that where the record is nonexistent or incomplete, the necessary and proper remedy is factfinding in the district court: "The task of the reviewing court is to apply the appropriate APA standard of review, 5 U.S.C. $\S 706$, to the agency decision based on the record the agency presents to the reviewing court." 144 This is because "agencies typically compile records in the course of informal agency action," and the "APA specifically contemplates judicial review on the basis of the agency record compiled in the course of informal agency action in which a hearing has not occurred." "Lorion referenced, but did not apply, the Overton Park "bare record" reasoning, stating that a court could set aside agency action "if the agency has not considered all relevant factors, or if the reviewing court simply cannot evaluate the challenged agency action on the basis of the record before it."146

139. 411 U.S. 138, 142 (1973). Like Overton Park, however, Camp did not comprehensively resolve the scope of the APA record, and so its brief treatment of the topic admits of some ambiguity. See, e.g., Susannah T. French, Judicial Review of the Administrative Record in NEPA Litigation, 81 CALIF. L. REV. 929, 944 (1993) (“Overton Park requires that a court's review be 'based on,' not limited to, the record before the agency.").

140. See Camp, 411 U.S. at 143.

141. Vt. Yankee Nuclear Power Corp. v. Nat. Res. Def. Council, Inc., 435 U.S. 519, 524 (1978).

142. Id. at 543.

143. 470 U.S. 729,744 (1985).

144. Id. at $743-44$.

145. Id. at 744 .

146. Id.; see also French, supra note 139 (summarizing Vermont Yankee and Lorion as "reflect[ing] a clear, if not very well-developed, preference for limiting judicial review to the agency record, regardless of the formality of the administrative proceedings"). 
In June 1990's Pension Benefit Guaranty Corp. v. LTV Corp., the Court extended to informal adjudication Vermont Yankee's prohibition on judicially imposing procedural requirements not derived from statute or the Constitution. ${ }^{147}$ LTV explained that the Overton Park record rule was fairly derived from the APA and so did not violate Vermont Yankee. $^{148}$

In the nearly thirty years since $L T V$, the Supreme Court has not decided a case directly addressing the record rule. It touched on the issue in late 2017 when several states and organizations sued the Department of Homeland Security for deciding to end the Deferred Action for Childhood Arrivals (DACA) program, which generally deprioritized immigration enforcement against aliens who came to the United States unlawfully as youths. ${ }^{149}$ Federal district judges in the Northern District of California ${ }^{150}$ and the Eastern District of New York ${ }^{151}$ ordered the Secretary of Homeland Security to produce documents and to sit for depositions beyond what she had identified as the administrative record.

To head off what the government viewed as very invasive and burdensome discovery that had already led to the production of 1.2 million documents from more than 100 custodians, ${ }^{152}$ the Secretary petitioned the Second and Ninth Circuits for writs of mandamus. ${ }^{153}$ When the Ninth Circuit denied the writ, the Secretary petitioned the Supreme Court for one and moved to stay the district court's order. ${ }^{154}$ In a case captioned In re United States, the Supreme Court granted the stay in a 5-4 decision that drew a dissent arguing that the district judge properly ordered completion of the administrative record. ${ }^{155}$ Just a week later, the Supreme Court granted the writ, vacated the judgment, and remanded to the Ninth Circuit to remand to the district court. ${ }^{156}$ The Supreme Court's unani-

\footnotetext{
147. See 496 U.S. 633 (1990).

148. Id. at 654 .

149. In re United States, 875 F.3d 1200, 1207 (9th Cir. 2017), vacated, 138 S. Ct. 443, 444.

150. Regents of Univ. of Cal. v. U.S. Dep’t of Homeland Sec., No. C 17-05211, 2017 WL 4642324, at *8 (N.D. Cal. Oct. 17, 2017).

151. Batalla Vidal v. Duke, No. 16-CV-4756, 2017 WL 4737280, at *6 (E.D.N.Y. Oct. 19, 2017)

152. Petition For Writ of Mandamus at 12, In re United States, 875 F.3d 1200 (9th Cir. 2017) (No. 17-72917), ECF No. 1-2.

153. In re Nielsen, No. 17-3345, 2017 U.S. App. LEXIS 26821, at *8 (2d Cir. Dec. 27, 2017); In re United States, 875 F.3d 1200, 1204 (9th Cir. 2017).

154. Petition For a Writ of Mandamus, In re United States, 138 S. Ct. 443 (2017) (No. 17-801), 2017 WL 6018231; Application for a Stay Pending Disposition of a Petition For a Writ of Mandamus, In re United States, 138 S. Ct. 371 (2017).

155. 138 S. Ct. $371,371$.

156. In re United States, 138 S. Ct. 443, 445 (2017).
} 
mous per curiam opinion granted the writ only because it believed the district judge erroneously picked up the APA record issues before addressing the Secretary's threshold jurisdictional arguments. ${ }^{157}$ As quickly as the issue shot up to the Supreme Court, the Supreme Court sent it back down without any new guidance to the bench and bar on the scope of the record rule. ${ }^{158}$ The only firm impression left by the Court's opinion was that disputes over the contents of the administrative record can be sufficiently important and burdensome that lower courts should be leery of uncritically ordering contested record production.

It is possible that the Supreme Court may revisit the issue. In October 2018, the Court in In re Department of Commerce stayed a district court order permitting APA petitioners to depose the Secretary of Commerce about his reasoning for including a citizenship question on the next decennial census. ${ }^{159}$ The Secretary had pressed that his deposition constituted evidence beyond what belonged in the APA record. ${ }^{160}$ The Court gave no reasoning for issuing its stay, but left open the possibility that the Secretary could petition for a writ of certiorari and receive a decision on the merits of the record scope. ${ }^{161}$

\section{HOW THE APA RECORD RULE SHOULD BE INTERPRETED IN PRACTICE}

With these background principles, we can discern what, precisely, "the whole record" means for APA judicial review. A court must look only at the agency record-"or those parts of it cited by a party"162 which is all materials compiled by the agency that were before the agency at the time the decision was made and considered by the agency. ${ }^{163}$ Thus, a court cannot order traditional civil discovery. ${ }^{164}$ Discovery may

\footnotetext{
157. Id

158. Id.

159. In re Dep't of Commerce, No. 18A375, 2018 WL 5259090, at *1 (U.S. Oct. 22, 2018)

(Gorsuch, J., concurring in part and dissenting in part) (describing the underlying factual dispute).

160. Id.

161. Id. at *1-2.

162. 5 U.S.C. $\$ 706(2012)$.

163. Camp v. Pitts, 411 U.S. 138, 142 (1973); Fla. Power \& Light Co. v. Lorion, 470 U.S. 729 , 743-44 (1985).

164. Because "the focal point for judicial review should be the administrative record already in existence, not some new record made initially in the reviewing court," Camp, 411 U.S. at 142, "[t]here is a strong presumption against discovery into administrative proceedings born out of the objective of preserving the integrity and independence of the administrative process." NVE, Inc. v. Dep't of Health \& Human Servs., 436 F.3d 182, 195 (3d Cir. 2006); accord USA Grp. Loan Servs. v. Riley, 82 F.3d 708, 715 (7th Cir. 1996) (Posner, C.J.) ("Discovery is rarely proper in the judicial review of administration action.”); Int'l Jr. Coll. Of Bus. \& Tech., Inc. v. Duncan, 937 F. Supp. 2d
} 
perhaps continue to be appropriate on non-merits threshold issues, such as jurisdictional discovery to determine standing, irreparable harm in the preliminary injunction context, or the like. Otherwise, an APA petitioner should not be allowed to serve interrogatories on an agency or notice the agency head for depositions. If a court concludes that the agency needs to add documents to the administrative record, an appropriate and common remedy is to remand to the agency for further proceedings. ${ }^{165}$

At most, the court should permit the parties to "complete" a record in appropriate circumstances, without obtaining discovery to do so. A court should not permit the parties, as has become the norm, to go beyond the administrative record by "adding to," "augmenting," or "supplementing" the agency record beyond the APA "whole record" (absent mutual consent of the parties). A full exploration of these concepts lays bare why completion is consistent with the APA and administrative judicial review whereas supplementation is not. This divergence is also wrapped up in the common conflation by judges and advocates alike of records issues with merits issues.

\section{A. How a Limited Completion Interpretation of "the Whole Record" Comports with the APA}

A narrow reading of "the whole record" follows from examining the rest of the APA, the Supreme Court's general administrative caselaw, the APA's legislative history, and the similarity of APA record review to ordinary appellate review. First, the APA's structure and purpose demonstrates that "the whole record" should be strictly limited to the materials that the agency decisionmaker considered. Except for unreasonable de-

202, 204-05 (D.P.R. 2012) ("[T] he narrowness of the APA action for judicial review weighs heavily against discovery[.]"), aff'd, 802 F.3d 99 (1st Cir. 2015). By "discovery," we mean simply the phase of litigation wherein the parties exchange information pursuant to court rules before trial-which encompasses both the supplementation of the APA record as well as traditional discovery. Our definition excludes, however, instances in which the agency produces documents on its own, either on its own initiative or by court order, that do not undergo the discovery process.

Some circuits nevertheless permit discovery, for example "in cases involving alleged bias on the part of the agency." NVE, 436 F.3d at 195 (citing Hummel v. Heckler, 736 F.2d 91 (3d Cir. 1984)) (permitting discovery on the issue of an ALJ's bias); Rochling v. Dep't of Veterans Affairs, 725 F.3d 927, 936 (8th Cir. 2013) (permitting discovery on a strong showing of bad faith or improper behavior). See also generally FED. R. CIV. P. 26 (exempting suits for review of agency action from many of the discovery requirements). This requirement also prevents litigants from circumventing principles of exhaustion, by seeking, receiving, and challenging evidence in the first instance in the federal court. See Fed. Power Comm'n v. Colo. Interstate Gas Co., 348 U.S. 492, 499-500 (1955) ("Section 10(e) of the Administrative Procedure Act does not require a different result. That Act purports to strengthen, rather than to weaken, the principle requiring the exhaustion of administrative remedies before permitting court review.").

165. E.g., Brodsky v. U.S. Nuclear Regulatory Comm'n, 704 F.3d 113, 124 (2d Cir. 2013). 
lay cases, ${ }^{166}$ APA judicial review is reserved for when the agency is finished either acting or not acting. ${ }^{167}$ A petitioner can challenge only a final agency action, ${ }^{168}$ which suggests that the agency record, at the time of judicial review, is complete. ${ }^{169}$ This is part of why, under the APA, "[r]eviews of agency action in the district courts must be processed as appeals." 170

Moreover, APA review is narrow and deferential, ${ }^{171}$ which is consistent with a cabined record on review. For one, the petitioner has the burden of proof in an APA action. ${ }^{172}$ And the APA extends deference to agencies consistent with Congressional intent. Deference to agencies is evidenced by: the language of the APA, which directs courts to uphold many aspects of agency action even if the courts carry differing opinions of the wisdom of those actions; ${ }^{173}$ the fact that agencies have more specialized experience than do generalist district courts; ${ }^{174}$ the fact that constitutionally speaking, agencies-which are helmed by officers of the United States who can be removed and indirectly checked by the political process, unlike life-tenured Article III judges - are better positioned than courts to make policy choices; ${ }^{175}$ and the broad investigative powers

\footnotetext{
166. 5 U.S.C. $\S 706(1)$.

167. See 5 U.S.C. $\S \S 551(13), 701(b)(2), 706$.

168. 5 U.S.C. $§ 704$; see Bennett v. Spear, 520 U.S. 154, 177-78 (1997).

169. Fla. Power \& Light Co. v. Lorion, 470 U.S. 729, 744 (1985).

170. Olenhouse v. Commodity Credit Corp., 42 F.3d 1560, 1579-80 (10th Cir. 1994).

171. See 5 U.S.C. § 706; Motor Vehicle Mfrs. Ass'n v. State Farm, 463 U.S. 29, 43 (1983).

172. E.g., 5 U.S.C. $\$ 706(2)(A)$; Hillsdale Envtl. Loss Prevention, Inc. v. U.S. Army Corps of Eng'rs, 702 F.3d 1156, 1165 (10th Cir. 2012); Sierra Club v. Marita, 46 F.3d 606, 619 (7th Cir. 1995).

173. 5 U.S.C. $§ 706$ (listing how the courts will defer to the agencies); e.g., Motor Vehicle Mfrs. Ass'n v. State Farm, 463 U.S. 29, 43 (1983); Citizens to Preserve Overton Park, Inc. v. Volpe, 401 U.S. 402, 416 (1971).

174. In re Sang Su Lee, 277 F.3d 1338, 1344 (Fed. Cir. 2002) ("The foundation of the principle of judicial deference to the rulings of agency tribunals is that the tribunal has specialized knowledge and expertise, such that when reasoned findings are made, a reviewing court may confidently defer to the agency's application of its knowledge in its area of expertise."); cf. Balt. \& Ohio R.R. Co. v. Aberdeen \& Rockfish R.R. Co., 393 U.S. 87, 92-93 (1968) (cautioning in an APA case against letting " $[\mathrm{t}]$ he requirement for administrative decisions based on substantial evidence and reasoned findings ... become lost in the haze of so-called expertise"); Stephen M. DeGenaro, Note, Why Should We Care About an Agency's Special Insight?, 89 NOTRE DAME L. REV. 909, 919 (2013) ("Whereas federal agencies may be devoted to a special field (e.g., the Occupational Safety and Health Administration and workplace safety), federal dockets contain a diverse array of cases—often in onerous quantities.").

175. Chevron, U.S.A., Inc. v. Nat. Res. Def. Council, Inc., 467 U.S. 837, 866 (1984) (“[F]ederal judges - who have no constituency — have a duty to respect legitimate policy choices made by those who do. The responsibilities for assessing the wisdom of such policy choices and resolving the struggle between competing views of the public interest are not judicial ones.”); Harold M. Greenberg, Why Agency Interpretations of Ambiguous Statutes Should Be Subject to Stare Decisis, 79 TENN. L. REV. 573, 590 (2012) (“Agency policy choices are not incidental and undesirable byprod-
} 
that agencies can have and which courts lack. ${ }^{176}$ This deference suggests that courts should take only the record before the agency and not consider other evidence not before the agency, which could cast the agency's decision in an unfavorable light.

Interpreting "the whole record" to mean all materials upon which the agency directly relied is also consistent with an influential Supreme Court case, SEC v. Chenery, Corp. ("Chenery I"), which predated the APA by three years and held that an agency may not defend an administrative decision on new grounds not set forth by the agency in its original decision. ${ }^{177}$ A strict record rule is a corollary to the Chenery I rule; by cutting off courts' inquiry at materials created contemporaneously with the decision making process, courts prevent agencies from slipping in post hoc rationalizations for the actions they took. The Chenery I doctrine is defensible in the APA context. For example, in Overton Park, two former and current Secretaries of Transportation rushed to prepare affidavits, around the holidays, that the Solicitor General presented in and tried to file with the Supreme Court the day of the oral argument. ${ }^{178}$ This "agency-reasoning-by-ambush" is but one reason to countenance the bar on post hoc rationalizations.

Next, interpreting the APA to require only this simple "whole record" comports with the Supreme Court's Vermont Yankee doctrine prohibiting courts from going beyond the APA to impose on agencies procedural requirements not found in the APA. ${ }^{179}$ One of those maximum requirements is in 5 U.S.C. $\S 706$, which embodies a "general "procedural' requirement of sorts [that] mandat[es] that an agency take whatever

ucts of the institution's task; they are the agencies' very raison d'etre.").

176. See Skidmore v. Swift \& Co., 323 U.S. 134, 139 (1944) ("But the Administrator's policies are made in pursuance of official duty, based upon more specialized experience and broader investigations and information than is likely to come to a judge in a particular case.").

177. 318 U.S. 80, 94-95 (1943); accord Yale-New Haven Hosp. v. Leavitt, 470 F.3d 71, 81 (2d Cir. 2006); Envtl. Def. Fund, Inc. v. Costle, 657 F.2d 275, 284 (D.C. Cir. 1981).

178. Jan. 11, 1971 Oral Argument at 2:38, Overton Park, 401 U.S. 402 (1971) (No. 1066), https://www.oyez.org/cases/1970/1066 [https://perma.cc/UD5A-3EX7] (“[COUNSEL FOR OVERTON PARK]: [A]pproximately 10 minutes ago[, ] the Solicitor General handed me two pieces of paper, which purport to be affidavits which I understand he is attempting to file in this case at this time, one of which says that as an affidavit of [Secretary] Alan S. Boyd and which he says as a matter of fact that he did make the determination which we have alleged he did not make and which we have offered to prove that he did not make. The second piece of paper which he has filed purports to be an affidavit of [successor Secretary] John Volpe that he made determinations."); Id. at 35:15 ("[SOLICITOR GENERAL]: We recognize that the presentation of these documents is unusual. We submit them for what effect they can properly be given ... We had them nicely printed up, but Secretary Volpe has been out of town. His affidavit was cleared with him by telephone.").

179. Vt. Yankee Nuclear Power Corp. v. Nat. Res. Def. Council, Inc., 435 U.S. 519, 524 (1978). 
steps it needs to provide an explanation that will enable the court to evaluate the agency's rationale at the time of decision."

Legislative history also provides some minimal support for our interpretation of "the whole record." As recounted earlier, the APA intended to carry forward the prevailing interpretation of the scope of the administrative record subject to judicial review. ${ }^{181}$ By 1946, that view was relatively pro-agency. Moreover, some scholars point to APA legislative history $^{182}$ to argue that all informal agency action was meant to be reviewed de novo under another section of the APA: 5 U.S.C. $\S$ 706(2)(F). ${ }^{183}$ This argument contends that Overton Park and its record rule are thus unfaithful to the APA in the context of informal agency action. But the exclusion of de novo review from the final bill suggests that Congress in fact did not want the courts to have a heavy influence in what materials the agency would consider and which the court could consider on judicial review.

Further, the properly interpreted record rule finds a companion in the law, through a parallel doctrine regarding record treatment in appellate review. Under that model, appellate courts reviewing the judgment of a district court review only the information that was presented in that tribunal. ${ }^{184}$ The reason has sound underpinnings. It respects trial processes for presenting, evaluating, and admitting evidence. ${ }^{185}$ It protects the fairness of the system to the parties. ${ }^{186}$ This model helps ensure accuracy through the advocacy of counsel and the evaluation of impartial judges and juries. ${ }^{187}$ It focuses appellate courts on their area of expertise, the resolution of questions of law, while recognizing the superior experience of trial courts in resolving questions of fact. ${ }^{188}$ These values are equally commendable in APA judicial review.

However, even the appellate rule of reviewing a limited record is not impervious. While the rule is exalted in sometimes moral terms, ${ }^{189}$ it too

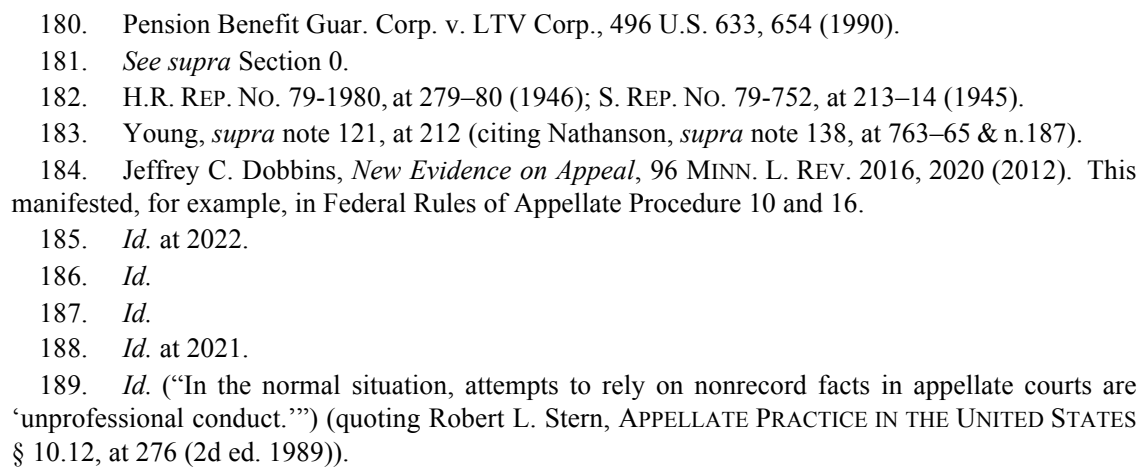

189. Id. ("In the normal situation, attempts to rely on nonrecord facts in appellate courts are 'unprofessional conduct."') (quoting Robert L. Stern, APPEllate PRACTICE IN THE United STATES $\S 10.12$, at $276(2 \mathrm{~d}$ ed. 1989$))$. 
has been susceptible to common-law carveouts: for example, amicus briefs, Brandeis briefs, and legislative facts. ${ }^{190}$ And there are differences between an Article III appellate court reviewing the record of a lower Article III court as in a typical appeal, and an Article III district court reviewing the record of an Article I agency as in a typical APA case. ${ }^{191}$ Nevertheless, Congress intended the APA to incorporate the traditional appellate model in its judicial-review provisions. ${ }^{192}$

Federal and local rules complement this concept. Closest to the appellate model, unsurprisingly, are the Federal Rules of Appellate Procedure. Rule 16(a) provides a bare-bones definition of the "record on review or enforcement of an agency order," which consists of: "(1) the order involved; (2) any findings or report on which it is based; and (3) the pleadings, evidence, and other parts of the proceedings before the agency." 193 Rule 17(b) then requires the agency to file either the record or a certified index of the record. ${ }^{194}$ Other rules service this limited definition of the record less explicitly. Federal Rule of Civil Procedure 26, for example, excuses litigants from the obligation to make initial disclosures if the case is founded on record review. ${ }^{195}$ Some courts' local rules exempt such suits from needing a scheduling order. ${ }^{196}$ Some rules are more substantive, making clear that the judicial record is coextensive with the agency record. ${ }^{19}$

Although this is the record rule as we interpret it through these varied sources, it again should be emphasized that organic statutes may impose different or additional requirements. ${ }^{198}$ In the absence of such statutes, the record rule applies to judicial review of all types of agency action: formal adjudication, informal adjudication, formal rulemaking, legislative rulemaking, non-legislative rulemaking, sub-regulatory policy

190. Id. at 2017; see generally Kenneth Culp Davis, An Approach to Problems of Evidence in the Administrative Process, 55 HARV. L. REV. 364, 406 (1942).

191. Dobbins, supra note 184, at 2027-28 (2012) (discussing the debate "regarding the proper role of administrative agencies," the lack of clear definition in an administrative record, and separation of powers concerns).

192. Thomas W. Merrill, Article III, Agency Adjudication, and the Origins of the Appellate Review Model of Administrative Law, 111 CoLUM. L. REV. 939, 942-43 (2011) ("The appellate review model was fully entrenched before the onset of the New Deal and was later incorporated into the Administrative Procedure Act in 1946.").

193. FED. R. APP. P. 16(a).

194. Id. R. 17(b)(1)(B).

195. FED. R. CIV. P. 26(a)(1)(B)(i).

196. S.D.N.Y. \& E.D.N.Y. CIV. R. 16.1.

197. D. Wyo. CIV. R. 83.6(b)(1). But see id. R. 83.6(b)(3) (permitting "supplementation of the record" in certain limited circumstances, upon motion filed within 14 days after the record is filed).

198. See supra note 68. 
statements, and agency inaction. ${ }^{199}$

\section{B. The Proper Means to Ensure the Court Reviews the Whole Record: Completion}

When built upon that foundation, the properly interpreted record rule leads easily to practical application distinct from the tangled, inconsistent doctrines created by case law. To ensure that the full administrative record is before the court, a court should permit, and indeed require, parties to "complete" the record where appropriate. By this, we mean to add documents that were properly part of the agency record but were not filed in court with that record. This is doctrinally appropriate because completion simply enforces the record rule, making the agency put up the full set of materials it considered. A party should not be able to use completion to propound discovery to find new records; completion should affect only what evidence the court considers. This is consistent with the more circumscribed scope of judicial review settled on by Congress when it passed the APA in 1946 after moving away from a more hands-off approach to judicial review but stopping well short of reestablishing judicial dominance in policing agency actions. ${ }^{200}$ It is also consistent with the appellate-style review with which APA judicial review shares many similarities. ${ }^{201}$

Completion should proceed as follows. For context, there is a longstanding presumption of agency regularity: "a presumption of honesty and integrity in those serving as adjudicators. ..."202 The presumption reinforces separation of powers, harmonizes with agency deference found in other contexts, and recognizes the practical reality that the agency has superior knowledge of what materials it considered. ${ }^{203}$ In APA cases that translates to a rebuttable presumption that the agency's record is complete. ${ }^{204}$ An APA petitioner must rebut the presumption be-

199. The APA "whole record" provision applies to challenges to "agency action." 5 U.S.C. $\S$ 706(1)-(2). The APA defines "agency action" broadly to "include[] the whole or a part of an agency rule, order, license, sanction, relief, or the equivalent or denial thereof, or failure to act," thus suggesting the "whole record" requirement applies to the above types of agency functions. See id. $\S \S 701(b)(2), 551(13)$.

200. See supra Section II.D.

201. See supra Section II.E.

202. Withrow v. Larkin, 421 U.S. 35, 47 (1975).

203. James N. Saul, Overly Restrictive Administrative Records and the Frustration of Judicial Review, 38 ENVTL. L. 1301, 1312 (2008).

204. Citizens to Pres. Overton Park, Inc. v. Volpe, 401 U.S. 402, 415 (1971) (citing United States v. Chem. Found., 272 U.S. 1, 14-15 (1926)); Estate of Landers v. Leavitt, 545 F.3d 98, 113 (2d Cir. 2008) ("The plaintiffs argue that this principle of judicial review creates a risk that agencies 
fore completion may occur. ${ }^{205}$

There are few ways that APA petitioners should be able to rebut the presumption of agency regularity in the compilation and presentation of the administrative record. First, a petitioner should be able to complete the record by adducing evidence demonstrating that the administrative record is not complete. This happens where the agency "deliberately or negligently excluded documents that may have been adverse to its decision." 206 The doctrine has variable phrasing: where the agency "relied on documents or materials not included in the record," 207 or the agency failed to include materials "available" to it, that it should have "considered." 208

This determination has many dimensions. The size of the record may be relevant. ${ }^{209}$ If the record references other parts of the record that are not present, or the record contains reports that could not have been made without other information not in the record, then incompleteness is

will be able to hoodwink courts into accepting agencies' self-interested justifications, but we are unwilling to ascribe such nefarious motives to agency action as a general matter."); see generally Note, The Presumption of Regularity in Judicial Review of the Executive Branch, 131 HARV. L. REV. 2431 (2018).

205. See Overton Park, 401 U.S. at 416; Bar MK Ranches v. Yuetter, 994 F.2d 735, 740 (10th Cir. 1993) ("[D]esignation of the Administrative Record, like any established administrative procedure, is entitled to a presumption of administrative regularity. The court assumes the agency properly designated the Administrative Record absent clear evidence to the contrary." (citing Wilson v. Hodel, 758 F.2d 1369, 1374 (10th Cir. 1985))); Univ. of Colo. Health at Mem'l Hosp. v. Burwell, 151 F. Supp. 3d 1, 12-13 (D.D.C. 2015) ("The record that an agency produces "is entitled to a strong presumption of regularity."” (quoting Marcum v. Salazar, 751 F. Supp. 2d 74, 78 (D.D.C. 2010),). Many cases caution that the ultimate authority to decide what constitutes the administrative record lies with the judiciary. E.g., Yuetter, 994 F.2d at 740.

206. BECK, supra note 35, at 67; see also Fund for Animals v. Williams, 391 F.Supp. 2d 191, 198 (D.D.C. 2005) (permitting supplementation "when an agency excludes information adverse to its position from the administrative record. A plaintiff can make a prima facie showing that an agency excluded adverse information from the record by proving that the documents at issue (1) were known to the agency at the time it made its decision, (2) are directly related to the decision, and (3) are adverse to the agency's decision.") (citation omitted) (internal quotation marks omitted).

207. Pub. Power Council v. Johnson, 674 F.2d 791, 794 (9th Cir. 1982); see also Yuetter, 994 F.2d at 739; Thompson v. U.S. Dep't of Labor, 885 F.2d 551, 555 (9th Cir. 1989); BECK, supra note 35 , at 67 .

208. Ad Hoc Metals Coal. v. Whitman, 227 F. Supp. 2d 134, 139-140,142 (D.D.C. 2002).

209. NVE Inc. v. Dep't of Health \& Human Servs., 436 F.3d 182, 196 (3d Cir. 2006) (“[T]he size of the record alone is not dispositive of the question of whether discovery is appropriate. Nevertheless, the size of the record is certainly a factor that a court should consider in deciding whether to take the unusual step of permitting invasive discovery into administrative decision-making."). Compare, e.g., Exxon Corp. v. Dep't of Energy, 91 F.R.D. 26, 39 (N.D. Tex. 1981) (126-page record found to be incomplete on its face), with Pac. Shores Subdivision Cal. Water Dist. v. U.S. Army Corps of Eng'rs, 448 F. Supp. 2d 1, 7 (D.D.C. 2006) ("The sheer volume and complexity of this administrative record suggests that it is complete."). Of course, the size of the record varies greatly. See supra notes 58-62 and accompanying text. 
likely. ${ }^{210}$ Petitioners often obtain through other means (for example, through the Freedom of Information $\mathrm{Act}^{211}$ ) documents that the agency presumptively had and considered, but that are not in the record shown to the court by the agency. ${ }^{212}$ An APA petitioner should then have to show specific facts demonstrating that the material was left out of the record, whether by accident or design: a "description and the date of the proffered exhibits," "when the documents were presented to the agency, to whom, and under what context," and "reasonable, non-speculative" grounds for the petitioner's belief that the materials were considered directly by the decisionmaker. ${ }^{213}$ However, even if the agency adds material to the agency record during litigation (perhaps because the agency uncovered documents which it had lost but which it had relied upon in taking its action), that alone does not establish that the agency is holding back other documents. ${ }^{214}$ This "obviously incomplete" ground for rebutting the presumption of agency regularity is not explicitly embraced by the APA, but its adoption is doctrinally proper; the doctrine simply holds the agencies to their APA record rule obligations.

That said, some federal appellate courts have defined the record to include all materials considered directly or indirectly by the decisionmaker. ${ }^{215}$ This definition of "the whole record" has proliferated and is used in several circuits, yet does not appear to have a principled origin. Indeed, there is no clear meaning as to what it means for a decisionmaker to have "indirectly" considered materials. Accordingly, "the whole record" should include only those materials that individuals working on the decision actually and directly considered. Nevertheless, at least one court has found the presumption of completeness rebutted when the agency had omitted the words "or indirectly" in its formulation of the record rule in its briefing, giving the judge the impression that the gov-

210. E.g., Buckingham Twp. v. Wykle, No. CIV. A 99-621, 2000 WL 233474, at*2 (E.D. Pa. Feb. 28, 2000).

211. 5 U.S.C. $\S 552$ (2012).

212. E.g., Outdoor Amusement Bus. Ass'n v. Dep't of Homeland Sec., No. ELH-16-1015, 2017 WL 3189446, at*16-17 (D. Md. July 27, 2017).

213. E.g., Pac. Shores Subdivision, Cal. Water Dist. v. U.S. Army Corps of Eng'rs, 448 F. Supp. 2d 1, 6-7 (D.D.C. 2006).

214. TOMAC v. Norton, 193 F. Supp. 2d 182, 195 (D.D.C. 2002) ("The fact that the defendants have supplemented the record with approximately 70 pages of additional information does not raise significant questions as to the completeness of the record, particularly when the supplementary material is accompanied by affidavits stating that searches were completed to ensure that no additional documents were omitted."), vacated, No. 01-0398, 2005 U.S. Dist. LEXIS 4633 (Mar. 24, 2005).

215. E.g., Pub. Power Council v. Johnson, 674 F.2d 791, 793-94 (9th Cir. 1982) (Kennedy, J.) (the first federal appeals court to use this formulation, quoting Overton Park and Camp v. Pitts); Bar MK Ranches v. Yuetter, 994 F.2d 735, 739 (10th Cir. 1993); accord In re United States, 138 S. Ct. 371, 372 (2017) (Breyer, J., dissenting from grant of stay). 
ernment was coyly withholding documents. ${ }^{216}$

Second, petitioners should be able to rebut the presumption agency regularity in the administrative record if the agency produces no record at all. ${ }^{217}$ This is grounded in 5 U.S.C. $§ 706$, which contemplates review of something ("the whole record"). ${ }^{218}$ It should be arbitrary or capricious for an agency to take an action, or to unreasonably delay taking an action, without any materials in front of the agency to inform or justify that decision. However, it is often unclear whether the agency lacks a record because it truly relied on absolutely nothing in acting, or because it is sluggish in compiling the record. ${ }^{219}$

Third, a court should be able to consider extra-record evidence of which it properly takes judicial notice. Theoretically, this is not "completing" the record; judicial notice puts more evidence before the court for it to consider. However, judicial notice should be available to federal courts as it is allowed by the Federal Rules of Evidence and pertains to a limited set of materials which should generally be beyond controversy. ${ }^{220}$ For example, a court should be able to take judicial notice of distances between cities, a fact basic enough that perhaps the parties simply assumed such as being within the ken of the agency and the regulated parties, but without which a court cannot quite reach a decision on the agency's action. Although each piece of evidence potentially subject to judicial notice must meet the strictures of the Federal Rules of Evidence, documents commonly subject to judicial notice outside of the APA context include transcripts of congressional hearing testimony ${ }^{221}$ and materials from the agency's website, ${ }^{222}$ though not an inspector general's report. $^{223}$ The view on judicial notice as it relates to the APA is not

216. Pitman v. U.S. Citizenship \& Immigration Servs., No. 2:17-cv-166, 2018 WL 3232355, at *3 (D. Utah July 2, 2018).

217. Citizens to Pres. Overton Park, Inc. v. Volpe, 401 U.S. 402, 419-20 (1971).

218. 5 U.S.C. § 706 (2012).

219. See, e.g., Overton Park, 401 U.S. at 420 (expressing that "the Secretary can ... require ... an adequate explanation for [the Secretary's] actions. Such an explanation will, to some extent, be a 'post hoc rationalization' and thus must be viewed critically.")

220. FED. R. EvID. 201(a), (b) (permitting a court in a civil action to take judicial notice of an adjudicative fact "that is not subject to reasonable dispute because it: (1) is generally known within the trial court's territorial jurisdiction; or (2) can be accurately and readily determined from sources whose accuracy cannot reasonably be questioned", but not extending to "legislative facts"). E.g., United States v. Lopez, 880 F.3d 974, 982 (8th Cir. 2018).

221. In re Moody's Corp. Sec. Litig., 599 F. Supp. 2d 493, 503-504 (S.D.N.Y. 2009); see also Whiting v. AARP, 637 F.3d 355, 364 (D.C. Cir. 2011) (finding no abuse of discretion where the district court declined to take judicial notice of congressional materials).

222. Kos Pharms., Inc. v. Andrx Corp., 369 F.3d 700, 705 n.5 (3d Cir. 2004).

223. Cty. of San Miguel v. Kempthorne, 587 F. Supp. 2d 64, 78 (D.D.C. 2008) ("The Court knows nothing about the investigative process which led to the report's conclusions, and it cannot 
universal. At least one federal district court has concluded that this is an inappropriate basis for completing or supplementing the record, ${ }^{224}$ and a federal court of appeals has implied the same. ${ }^{225}$

Finally, courts should permit the parties to add materials to the record upon joint stipulation. ${ }^{226}$ The APA does not appear to explicitly permit this procedure, but it is not obvious why the court should stop the parties from doing so. If the agency concludes that its decision is sound but requires a fuller, extra-record basis (perhaps the issue is highly technical and requires a background explanation of the field), then it will save time and resources for the court to review the agency's decision sooner, rather than later after a remand to add these categories. If the agency has concluded that adding material does not hamper its missionand so long as the material does more than serve a forbidden post hoc rationalization - then the court should defer to the agency.

\section{What Does Not Belong in the Record}

Beyond these limited categories of documents, other documents do not belong in the record. An agency may use these definitional noninclusions or privileges to justify nonproduction or redaction, and so a court should not order the agency to complete or supplement the record with those materials. ${ }^{227}$ Courts disagree, however, and have several categories of documents which they allow to be added to the administrative record or to justify discovery from the agency. ${ }^{228}$ We count at least six such categories, although courts' formulations vary from case to case, even within the same circuit.

First, the agency's deliberative process does not fall within scope of

access the report's validity. ...").

224. Silver State Land, LLC v. Beaudreau, 59 F. Supp. 3d 158, 172 (D.D.C. 2014) ("Judicial notice is 'typically an inadequate mechanism' for a court to consider extra-record evidence in reviewing an agency action. 'Instead, a court may only consider an adjudicative fact subject to judicial notice that is not part of the administrative record if it qualifies for supplementation as extra-record evidence ..."” (quoting Dist. Hosp. Partners, L.P. v. Sebelius, 971 F. Supp. 2d 15, 32 n.14 (D.D.C. 2013)) (citation omitted)).

225. Budhathoki v. Nielsen, 898 F.3d 504, 517 (5th Cir. 2018) (denying the plaintiffs' motion to take judicial notice of certain state-court orders, concluding that "[ $\mathrm{t}$ ] hese documents are not part of the administrative record, could not have been considered by the agency making the decision, and are therefore irrelevant to this appeal." (citing Camp v. Pitts, 411 U.S. 138, 142 (1973))).

226. Bos. Redevelopment Auth. v. Nat'l Park Serv., 838 F.3d 42, 48 (1st Cir. 2016); Walter O. Boswell Mem'l Hosp. v. Heckler, 749 F.2d 788, 794 (D.C. Cir. 1984).

227. Izaak Walton League v. Marsh, 655 F.2d 346, 370 (D.C. Cir. 1981) (finding the principle "well established" that "an agency may claim a privilege with respect to documents that may have influenced a particular decision").

228. See infra notes 215-255 and accompanying text. 
"the whole record." 229 The deliberative-process principle excludes materials from an administrative record if they are privileged and deliberative in nature: "documents that reflect advisory opinions, recommendations and deliberations comprising part of a process by which government decisions and policies are formulated." 230 Some courts have recognized a "consultant corollary" doctrine that "protects documents between the agency and third parties enlisted to assist the agency in their decisionmaking process. $" 231$

Courts have good reason to protect materials reflecting the agency's deliberative process. Deliberative process is central to the operation of the administrative state. ${ }^{232}$ The doctrine advances "the policy of open, frank discussion between subordinate and chief concerning administrative action," 233 allowing decisionmakers to freely "explore possibilities, engage in internal debates, or play devil's advocate without fear of public scrutiny." ${ }^{234}$ The protection thus shields "premature disclosure of proposed policies before they have been finally formulated or adopted."235 The doctrine also prevents "confusing the issues and misleading the public by dissemination of documents suggesting reasons and rationales for a course of action which were not in fact the ultimate reasons for the agency's action." ${ }^{236}$ The protection serves to improve the quality of the agen-

229. E.g., Ocean, Inc. v. Ross, 290 F. Supp. 3d 73, 82-83 (D.D.C. 2018) (Courts in this District have long held that materials that fall within the scope of the deliberative process privilege are not part of the administrative record.").

230. F.T.C. v. Warner Commc'ns Inc., 742 F.2d 1156, 1161 (9th Cir. 1984) (citing NLRB v. Sears, Roebuck \& Co., 421 U.S. 132, 150 (1975)); see also, e.g., Town of Norfolk v. U.S. Army Corps of Eng'rs, 968 F.2d 1438, 1458 (1st Cir. 1992) (holding that to fall within deliberative process, the materials must be (1) pre-decisional and (2) deliberative, that is, actually expressing an opinion on a policy); Utah Med. Prods. v. McClellan, No. 2:03-CV-00525, 2004 WL 988877, at *2 (2004) (internal quotations omitted) (finding the deliberative process privilege applies when documents are "pre-decisional" and "deliberative"); Nat'l Wildlife Fed'n v. U.S. Forest Serv., 861 F.2d 1114, 1117 (9th Cir. 1988) (same). One scholar argues that the deliberative process doctrine's "roots lie in a now discredited 1841 decision of the British House of Lords," and that the doctrine was "rooted in the need to protect sensitive military information." Michael Ray Harris, Standing in the Way of Judicial Review: Assertion of the Deliberative Process Privilege in APA Cases, 53 ST. LoUIS U. L.J. 349, 359-61 (2009) (citations omitted).

231. Stand Up for Cal.! v. U.S. Dep’t of Interior, 315 F. Supp. 3d 289, 298 (D.D.C. 2018).

232. William R. Sherman, The Deliberation Paradox and Administrative Law, 2015 B.Y.U. L. REV. 413, 417-23 (citing Chevron, U.S.A., Inc. v. Nat. Res. Def. Council, Inc., 467 U.S. 837, 866 (1984)) (describing the centrality of the deliberation process in administrative law and the judicial respect for that process generally using the APA's instructions for adjudication and rulemaking (e.g., $\S \S 553$ 's and 554's requirements that the agency must consider facts and arguments)).

233. Kaiser Aluminum \& Chem. Corp. v. United States, 141 Ct. Cl. 38, 48 (1958) (Reed, J. (ret.), sitting by designation). Kaiser Aluminum, although cited in APA cases, was not an APA case.

234. Assembly of Cal. v. U.S. Dep't of Commerce, 968 F.2d 916, 920 (9th Cir. 1992).

235. Coastal States Gas Corp. v. Dep't of Energy, 617 F.2d 854, 866 (D.C. Cir. 1980).

236. Id. 
cy's policy decisions.

There is a circuit split over whether deliberative process materials belong in the APA record and must be logged as privileged. Many courts find the material to be definitionally part of the record, ${ }^{237}$ but privileged and qualified. ${ }^{238}$ Courts are also split on whether a privilege log is required. ${ }^{239}$ Circuits allowing a deliberative-process protection often impose requirements for its invocation. ${ }^{240}$ Courts may require the purportedly deliberative documents to be logged and reviewed upon challenge in camera. $^{241}$

Other courts conclude that deliberative process materials need not be disclosed because of the prudential concerns about exposing the agency's

237. E.g., In re United States, 875 F.3d 1200, 1207 (9th Cir. 2017) (interpreting the Ninth Circuit's definition of the administrative record-"all documents and materials directly or indirectly considered by agency decision-makers" - to include "materials relied on by subordinates who directly advised the ultimate decision-makers." (quoting Thompson v. U.S. Dept. of Labor, 885 F.2d 551, 555 (9th Cir. 1989))), rev'd, 138 S. Ct. 443.

238. See, e.g., In re United States, 138 S. Ct. 371, 371 (2017) (granting stay of discovery orders pending disposition of the petition for writ of certiorari or mandamus); Utah Med. Prod. v. McClellan, No. 2:03-CV-00525, 2004 WL 988877, at *2 (D. Utah Mar. 31, 2004) (deeming a particular document to be covered under the deliberative process privilege after (1) inquiring whether "the privilege applies to the documents at issue", and (2) balance[ing] "the parties' interests to determine whether the documents should be produced, even if they are deliberative" with the burden on the agency for (1) and the petitioner for (2)); In re Sealed Case, 121 F.3d 729, 737 (D.C. Cir. 1997) (stating that a showing of "compelling need" can overcome the qualified deliberative process privilege); Ctr. For Biological Diversity v. U.S. Army Corps of Eng'rs, No. CV 14-1667, 2015 WL 3606419, at *3 (N.D. Cal. Feb. 4, 2015) (adopting the same test); Branch v. Phillips Petroleum Co., 638 F.2d 873, 882 (5th Cir. Unit A 1981) ("[P]urely factual information is not protected by the privilege.").

239. The D.C. Circuit does not require a privilege log. Oceana, Inc. v. Pritzker, 217 F. Supp. 3d 310,320 (D.D.C. 2016) (collecting cases and holding that "[to require] all predecisional and deliberative documents ... be logged in a Vaughn-type index would place a significant burden on agencies whose decisions are challenged as arbitrary and capricious."); see also Stand Up for Cal.! v. Dep't of Interior, 71 F. Supp. 3d 109, 123 (D.D.C. 2014) (“'P]rivileged and deliberative materials are not part of the administrative record as a matter of law."); Nat'l Ass'n of Chain Drug Stores v. U.S. Dep't of Health \& Human Servs., 631 F. Supp. 2d 23, 27 (D.D.C. 2009). Other courts require a privilege log for assertion of the deliberative process exemption. E.g., Cal. Native Plant Soc'y v. U.S. E.P.A., 251 F.R.D. 408, 413 (N.D. Cal. 2008); see also New York v. Salazar, 701 F. Supp. 2d 224, 239 (N.D.N.Y. 2010), report and recommendation adopted, No. 6:08-CV-644, 2011 WL 1938232 (N.D.N.Y. Mar. 8, 2011).

240. ARKRAY USA, Inc. v. United States, No. 14-233C, 2014 WL 2905127, at *4 n.15 (Fed. Cl. Apr. 28, 2014) (requiring for invocation of the deliberative-process privilege that (1) the agency head or an authorized delegate assert the privilege, (2) state with particularity what information is to be excluded, and (3) provide the court with precise or certain reasons for maintaining the confidentiality); see also, Branch, 638 F.2d at 882-83 (5th Cir. Unit A 1981). One circuit judge in dissent has argued that the deliberative-process privilege may be invoked only by an agency head. Marriott Int'1 Resorts, L.P. v. United States, 437 F.3d 1302, 1308-09 (Fed. Cir. 2006) (Mayer, J., dissenting).

241. See, e.g., In re United States, 875 F.3d at 1210 (citing district courts within the Ninth Circuit), rev'd, 138 S. Ct. 443. 
internal deliberations. ${ }^{242}$ Alternatively, many courts find that deliberative process materials do not fall within the definition of an APA record because pre-decisional views do not constitute the final agency action as required for judicial review under 5 U.S.C. $\S 706 .{ }^{243}$

There are limitations to the non-record designation of process materials. Some courts permit a litigant who meets Overton Park's "strong showing of bad faith or improper behavior" standard to make the decision-making process itself the subject of the litigation, and thus be permitted to discover the agency's deliberative process. ${ }^{244}$ Some courts

242. E.g., FED. R. APP. 16, 17; San Luis Obispo Mothers for Peace v. U.S. Nuclear Regulatory Comm'n, 789 F.2d 26, 45 (D.C. Cir. 1986) (en banc); Town of Norfolk v. U.S. Army Corps of Eng'rs, 968 F.2d 1438, 1458 (1st Cir. 1992); In re U.S. Dep't of Def. \& U.S. Envtl. Prot. Agency Final Rule, No. 15-3751, 2016 WL 5845712, at *2 (6th Cir. Oct. 4, 2016) ("Deliberative process materials are generally exempted from inclusion in the record in order to protect the quality of agency decisions by ensuring open and candid communications."); Tafas v. Dudas, 530 F. Supp. 2d 786, 794 (E.D. Va. 2008) ("First, judicial review of agency action should be based on an agency's stated justification, not the predecisional process that led up to the final, articulated decision.... Second, excluding deliberative materials prevents injury to the quality of agency decisions by encouraging uninhibited and frank discussion of legal and policy matters." (internal quotation marks and alterations omitted)), vacated and remanded sub nom, 328 Fed. Appx. 658 (Fed. Cir. 2009); Carlsson v. U.S. Citizenship \& Immigration Servs., No. 2:12-cv-7893, 2015 WL 1467174, at *7 n.5 (C.D. Cal. Mar. 23, 2015); Madison Cty. Bldg. \& Loan Ass'n v. Fed. Home Loan Bank Bd., 622 F.2d 393, 395 n.3 (8th Cir. 1980) (indicating in dicta that "staff memoranda and recommendations ... used by an agency in reaching a decision ... may be excluded from the record because of concerns over proper agency functioning.").

This is the subject of a recent case before the U.S. Supreme Court, In re United States, where the agency argued, "Nothing in the APA suggests that an agency compiling a record for informal agency action must include every piece of paper that might touch on the subject, and this Court has made clear that courts are not authorized to add to the APA's requirements." Reply Brief for the Petitioners at *4, In re United States, 138 S. Ct. 443 (2017) (No. 17-801) (citing Vt. Yankee Nuclear Power Corp. v. Nat. Res. Def. Council, Inc., 435 U.S. 519, 549 (1978)), rev'd, 138 S. Ct. 443 (2017).

243. E.g., In re Subpoena Duces Tecum Served on the Office of the Comptroller of the Currency, 156 F.3d 1279, 1279-80 (D.C. Cir. 1998) ("Agency deliberations not part of the record are deemed immaterial. ... That is because the actual subjective motivation of agency decisionmakers is immaterial as a matter of law...."); San Luis Obispo Mothers for Peace, 789 F.2d at 45; Town of Norfolk, 968 F.2d at 1458; In re U.S. Dep't of Def. \& U.S. Envtl. Prot. Agency Final Rule, 2016 WL 5845712, at *2 ("Deliberative process materials are generally exempted from inclusion in the record in order to protect the quality of agency decisions by ensuring open and candid communications."); Tafas, 530 F. Supp. 2d at 794 ("First, judicial review of agency action should be based on an agency's stated justification, not the predecisional process that led up to the final, articulated decision.... Second, excluding deliberative materials prevents injury to the quality of agency decisions by encouraging uninhibited and frank discussion of legal and policy matters." (internal quotation marks and alterations omitted)).

244. Salazar, 701 F. Supp. 2d at 238; see also In re Subpoena Duces Tecum Served on the Office of the Comptroller of the Currency, 156 F.3d at 1280 ("[O]ur holding that the deliberative process privilege is unavailable is limited to those circumstances in which the cause of action is directed at the agency's subjective motivation."); Bethlehem Steel Corp. v. EPA, 638 F.2d 994, 1000 (7th Cir. 1980) (requiring deliberative documents where plaintiff "contends that Agency personnel improperly commingled adjudicative and prosecutorial functions and relied upon improper ex parte communications in arriving at the decision. ..."), vacated, 732 F.2d 97 (1984). Courts permit APA 
have found that assertions of deliberative process are subject to waiver. ${ }^{245}$ The deliberative-process privilege has been criticized as abused by, and overly deferential to, the federal government. ${ }^{246}$

Because these materials do not belong in the record in the first place, no $\log$ is required for deliberative-process material not included in the administrative record. ${ }^{247}$ In other words, whether the deliberativeprocess material is privileged is irrelevant. A court may prefer to review the withheld or redacted information in camera to ensure it is properly outside the scope of the record (e.g., deliberative process) or properly privileged. ${ }^{248}$ A court may also require the government file the unredacted version under seal. ${ }^{249}$

A second class of materials that does not compose "the whole record" is privileged material—besides deliberative-process materialwhich may be redacted or excluded and logged. One type of common administrative record privilege is the attorney-client privilege. ${ }^{250}$ The attorney-client privilege protects communications between attorneys and their client agencies that provide confidential information or legal advice. $^{251}$ APA cases apply non-APA case law for this privilege. ${ }^{252}$ In the

petitioners to make the decision-making process the subject of the litigation despite the fact that, as discussed later, the "bad faith or improper behavior" exception is a merits issue and not a records issue. See infra Section IV.B.

245. Miami Nation of Indians of Ind., Inc. v. Babbitt, 979 F. Supp. 771, 777-79 (N.D. Ind. 1996) (requiring addition of deliberative documents and draft reports to the administrative record but allowing the government to seek a protective order to assert deliberative process privilege).

246. Harris, supra note 230, at 404-11.

247. Great Am. Ins. Co. v. United States, No. 12-C-9718, 2013 WL 4506929, at *8 (N.D. Ill. Aug. 23, 2013) ("The law is clear: [since] predecisional and deliberative documents 'are not part of the administrative record to begin with,' . . . they 'do not need to be logged as withheld from the administrative record."” (quoting Oceana, Inc. v. Locke, 634 F. Supp. 2d 49, 52 (D.D.C. 2009))).

248. E.g., Nat'l Courier Ass'n v. Bd. of Govs. of Fed. Reserve Sys., 516 F.2d 1229, 1243 (D.C. Cir. 1975) (finding no significant omission and denying petitioners' request for disclosure of the redacted portions of internal agency memoranda); Smith v. Brady, 813 F. Supp. 1382, 1386 (E.D. Wis. 1993).

249. E.g., Poett v. United States, 657 F. Supp. 2d 230, 234 n.2 (D.D.C. 2017).

250. Modesto Irrigation Dist. v. Gutierrez, No. 1:06-CV-00453, 2007 WL 763370, at*12 (E.D. Cal. Mar. 9, 2007) ("As with the deliberative process privilege, the attorney-client privilege is applicable in administrative record cases.”); New York v. Salazar, 701 F. Supp. 2d 224, 239 (N.D.N.Y. 2010), report and recommendation adopted, No. 6:08-CV-644, 2011 WL 1938232 (N.D.N.Y. Mar. $8,2011)$.

251. The Ninth Circuit, for example, applies the privilege as follows:

(1) where legal advice of any kind is sought,(2) from a professional legal adviser in his capacity as such,

(3) [to] the communications relating to that purpose,

(4) made in confidence

(5) by the client,

(6) [which] are at the client's instance permanently protected 
APA context, the privilege applies where the agency is the client and a government attorney is counsel. ${ }^{253}$ Some courts of appeal are imprecise about how broadly the privilege may be asserted: "Because the attorneyclient privilege obstructs the truth-finding process, it is construed narrowly." 254 But, "there may be an unusual and extraordinary circumstance where a document protected by the attorney-client privilege should be made part of the administrative record." 255

Another privilege protects attorney work product. This privilege provides qualified protection for tangible material prepared in anticipation of litigation by a party or its representative. ${ }^{256}$ The Supreme Court has expressed solicitude for the "inviolate" doctrine, reasoning that absent the doctrine, "[i]nefficiency, unfairness and sharp practices would inevitably develop in the giving of legal advice and in the preparation of cases for trial.... [T] he interests of the clients and the cause of justice would be poorly served." 257

The privilege protecting agency work product is qualified because the APA petitioner may access fact work product if it is otherwise discoverable and if the party demonstrates a "substantial need for the materials to prepare its case and cannot, without undue hardship, obtain their substantial equivalent by other means." ${ }^{, 258}$ If these conditions are met,

(7) from disclosure by himself or by legal adviser

(8) unless the protection [is] waived.

Matter of Fischel, 557 F.2d 209, 211 (9th Cir. 1977); accord Tax Analysts v. IRS, 117 F.3d 607, 618 (D.C. Cir. 1997) ("The attorney-client privilege protects confidential communications from clients to their attorneys made for the purpose of securing legal advice or services." (citing In re Sealed Case, 737 F.2d 94, 98-99 (D.C. Cir. 1984))).

252. Modesto Irrigation Dist., 2007 WL 763370, at*13.

253. E.g., Tax Analysts, 117 F.3d at 618.

254. Westinghouse Elec. Corp. v. Republic of Phil., 951 F.2d 1414, 1423 (3d Cir. 1991) (collecting cases from the D.C., Third, and Seventh Circuits).

255. Town of Norfolk v. U.S. Army Corps of Eng'rs, 968 F.2d 1438, 1458 (1st Cir. 1992). This privilege can be waived through disclosure of the protected material to a third party, so the material might be subject to inclusion in the administrative record. See, e.g., United States v. Dakota, 197 F.3d 821, 825 (6th Cir. 1999); Westinghouse Elec., 951 F.2d at 1422; McDonnell Douglas Corp. v. EEOC, 922 F. Supp. 235, 243 (E.D. Mo. 1996); Fort James Corp. v. Solo Cup Co., 412 F.3d 1340, 1349-50 (Fed. Cir. 2005) ("There is no bright line test for determining what constitutes the subject matter of a waiver, rather courts weigh the circumstances of the disclosure, the nature of the legal advice sought and the prejudice to the parties of permitting or prohibiting further disclosures.").

256. Ocean Mammal Inst. v. Gates, No. 07-254, 2008 WL 2185180, at*10 (D. Haw. May 27, 2008) (citing Hickman v. Taylor, 329 U.S. 495 (1947)).

257. Hickman v. Taylor, 329 U.S. 495, 511 (1947), superseded by statute, FED. R. CIV. P. 26(b).

258. FED. R. CIV. P. 26(b)(3)(A)(ii); see also, Office of Thrift Supervision v. Vincent \& Elkins, LLP, 124 F.3d 1304, 1307 (D.C. Cir. 1997) (“A party can discover fact work product upon showing a substantial need for the materials and an undue hardship in acquiring the information any other way. Opinion work product, on the other hand, is virtually undiscoverable." (citing Upjohn Co. v. 
then the agency's work product must be furnished to the petitioner. ${ }^{259}$

Another privilege that expectedly arises when dealing with the federal government covers classified information. Some courts require unclassified summaries of classified evidence. ${ }^{260}$ Courts should carefully evaluate privilege claims of classified information because federal regulations govern permissible agency disclosure. ${ }^{261}$

Some materials are not privileged but are protected resources nonetheless. Copyrighted material, for example, may appear in the record either directly, or the record may reflect incorporation of copyrighted standards. ${ }^{262}$ The agency "may be prohibited from publishing that material absent consent of the copyright owner." 263 This protection is not specific to the administrative record or APA contexts. ${ }^{264}$ This issue may be particularly problematic for agencies facing APA litigation because many courts require the agencies to file the administrative records on the public docket as opposed to simply producing the administrative records to the opposing party. ${ }^{265}$ Filing the administrative records would permit individuals to view and copy the material without paying royalties. ${ }^{266}$ Therefore, some agencies like the Department of Transportation, the Occupational Safety and Health Administration, and the Food and Drug Administration insert a notice into the record that copyrighted material composing the record will not be shown and the interested reader must contact the court clerk's office to view the copyrighted material in hard copy form. ${ }^{267}$

Confidential business information and trade secrets merit similar solicitude. Some agencies, like the Federal Trade Commission, are statutorily charged with protecting confidential business information and trade

\footnotetext{
United States, 449 U.S. 383, 401-02 (1981))).

259. See FED. R. CIV. P. 26(b)(3)(B) (providing greater protection for opinion work product); Ocean Mammal Inst., 2008 WL 2185180, at *13 (assessing whether attorney work-product was discoverable in an APA action); cf. CP Salmon Corp. v. Pritzker, 238 F. Supp. 3d 1165, 1176-77 (D. Alaska 2017) (ordering the petitioners to return attorney work product that had been inadvertently included in the record, and the agency to file a revised administrative record).

260. See, e.g., Al Haramain Islamic Found. v. U.S. Dep't of Treasury, 686 F.3d 965, 980-85 (9th Cir. 2012); Holy Land Found. v. Ashcroft, 333 F.3d 156, 164 (D.C. Cir. 2003) (citing People's Mojahedin Org. of Iran v. Dep't of State, 327 F.3d 1238, 1242-43 (D.C. Cir. 2003); Global Relief Found., Inc. v. O'Neill, 315 F.3d 748, 754 (7th Cir. 2002).

261. E.g., 28 C.F.R. § 17 (2012); Exec. Order No. 13,526, 75 Fed. Reg. 707 (Jan. 5, 2010).

262. BECK, supra note 35 , at 50-52.

263. Id. at 51 .

264. Id. at 50-52.

265. Id. at 51-52.

266. Id.

267. Id. at 51 .
} 
secrets. $^{268}$ Other agencies address the problem on the front end. ${ }^{269}$ For example, some warn the public that any confidential business information included with public comments will be made public in an administrative record. ${ }^{270}$

Finally, some subject-matter-specific statutes concern an agency's ability to disclose certain information, like the Bank Secrecy Act, ${ }^{271}$ the Illegal Immigration Reform and Immigrant Responsibility Act of 1996's protections of asylum information, ${ }^{272}$ or the Internal Revenue Code's protections of taxpayer return information. ${ }^{273}$

The contours of "the whole record" depend on the subject matter, the context, and the circuit in which APA review is sought. Even when the standards are ascertainable, they are often imprecise. It is amid this imprecision that the bench and bar begin to stray into materials that clearly do not belong in "the whole record."

\section{Supplementation Is an Improper Means of Inserting Documents into an APA Administrative Record}

Having plumbed the proper interpretation of "the whole record" by explaining the limited instances in which a court may consider documents beyond those presented by an agency and flagging instances in which documents may nonetheless be excluded from the administrative record, we now turn to the circumstances under which APA petitioners improperly try to supplement the record with additional documents.

Petitioners can circumvent the APA's record rule in a number of ways. Petitioners may bring constitutional or non-APA claims challenging agency action and claim those arguments exempt them from the record rule. ${ }^{274}$ In one practice, petitioners acknowledge the prevalence of

\footnotetext{
268. Id. at 53 n.316 (citing 15 U.S.C. $\S 46(f) ; 16$ C.F.R. $\S \S 4.9-.10$ ).

269. Id. at 53 .

270. Id.

271. 31 U.S.C. $\S 5318(\mathrm{~g})(2)(2012) ; 12$ C.F.R. § 21.11(k) (2012).

272. 8 U.S.C. $\$ 1367$ (b) (2012).

273. 26 U.S.C. $\$ 6103$ (2012). Although sensitive information such as financial account numbers ordinarily must be redacted in civil litigation, FED. R. CIV. P. 5.2(a)(4), that requirement does not apply to APA records, FED. R. CIV. P. 5.2(b)(2).

274. See Webster v. Doe, 486 U.S. 592, 603 (1988) (holding that although the National Security Act of 1947 precluded APA review of a due process claim, that claim was reviewable outside the APA structure: "[W]here Congress intends to preclude judicial review of constitutional claims its intent to do so must be clear.").

To invoke judicial review on a constitutional claim notwithstanding the APA, the petitioner must allege "at least a colorable constitutional violation." Torres-Aguilar v. INS, 246 F.3d 1267, 1271 (9th Cir. 2001) ("[A] petitioner may not create the jurisdiction that Congress chose to remove
} 
the "whole record" rule, but argue that for various reasons they should be able to "supplement" the record with documents that they already possess or that they seek to discover from the agency. ${ }^{275}$

Generally, courts and scholars divide additions of materials to the judicial record into two categories. First, completion, as discussed above, adds material that was considered by the agency but not included in the record. ${ }^{276}$ Such documents inextricably compose "the whole record." In contrast, the second category, supplementation, is "a circumstance in which a party seeks to add extra-record or extra-judicial information to the record that was concededly not before the agency."277 Petitioners may make the same argument under the banner of completion, supplementation, or both, and courts are not consistent on terminology, often conflating the two. ${ }^{278}$ Petitioners may ask courts to use discovery to conduct completion or supplementation, instead of remanding to the agency (regardless of vacatur or retention of jurisdiction). ${ }^{279}$

The landscape of completion and supplementation, as practiced, is unkempt terrain. Courts disagree as to which exceptions exist, how to prove them, and how to classify them. Moreover, some disagreements are not just among circuits, but also intra-circuit. ${ }^{280}$

\footnotetext{
simply by cloaking an abuse of discretion argument in constitutional garb."); compare, e.g., Chiayu Chang v. U.S. Citizenship \& Immigration Servs., 254 F. Supp. 3d 160, 163 (D.D.C. 2017) (rejecting such a claim stating "[p]laintiffs cite no authority for the proposition that the retroactivity claim is a separate cause of action that exists outside the APA and is therefore exempt from the record review rule" (emphasis in original)), and Jarita Mesa Livestock Grazing Ass'n v. U.S. Forest Serv., 58 F. Supp. 3d 1191, 1238 (D.N.M. 2014) (denying discovery on First Amendment claim stating "allow[ing] fresh discovery, submission of new evidence and legal arguments ... [would] incentivize every unsuccessful party to agency action to allege ... constitutional violations to trade in the APA's restrictive procedures for the more even-handed ones of the Federal Rules of Civil Procedure"), with Carlsson v. U.S. Citizenship \& Immigration Servs., No. 2:21-cv-7893, 2015 WL 1467174, at*13-14 (C.D. Cal. Mar. 23, 2015) (limiting discovery on a non-APA claim).

275. BECK, supra note 35, at 69-71.

276. See supra Section III.B.

277. Oceana, Inc. v. Ross, 290 F. Supp. 3d 73, 78 (D.D.C. 2018) (quoting Univ. of Colo. Health at Mem. Hosp. v. Burwell, 151 F. Supp. 3d 1, 13 (D.D.C. 2015) (internal quotation marks and emphasis omitted)).

278. E.g., Stand Up for Cal.! v. U.S. Dep't of Interior, 315 F. Supp. 3d 289, 294 (D.D.C. 2018) (referencing a plaintiffs' "Mot. To Complete and/or Supplement the Administrative R. and for Leave to Conduct Disc."); Lands Council v. Forester of Region One of the U.S. Forest Serv., 395 F.3d 1019, 1030 (9th Cir. 2005) (referencing an internally inconsistent maxim that "a reviewing court may require supplementation of the administrative record if it is incomplete." (citing Camp v. Pitts, 411 U.S. 138, 142-43 (1973))).

279. See, e.g., Little Co. of Mary Hosp. v. Sebelius, 587 F.3d 849, 856 (7th Cir. 2009).

280. See, e.g., Axiom Res. Mgmt., Inc. v. United States, 564 F.3d 1374, 1380-81 (Fed. Cir. 2009) (identifying tension within the D.C. Circuit on this issue); Ctr. for Native Ecosystems v. Salazar, 711 F. Supp. 2d 1267, 1278-79 (D. Colo. 2010) (identifying tension within the Tenth Circuit on this issue).
} 
While nominal completion is generally a permissible basis to rebut the presumption of agency regularity, there is a notable exception. Overton Park notes that a court may permit the record to be completed upon "a strong showing of bad faith or improper behavior."" record supplementation has no textual grounding in the APA and was created by the Court, without citation or explanation, to facilitate Article III review. ${ }^{282}$ More precisely, Overton Park said that a strong showing of bad faith or improper behavior permitted the courts to "require the administrative officials who participated in the decision to give testimony explaining their action[s]." ${ }^{283}$ The "bad faith or improper behavior" language, however, has since been interpreted to permit a court to allow any type of record supplementation. ${ }^{284}$ This method for determining bad faith and improper behavior theoretically applies with both subtraction (failing to include documents adverse to the agency decision) and addition (improperly adding to the records documents favorable to the agency decision - that is, verboten post hoc rationalizations). ${ }^{285}$

Courts vary on what meets this standard but they have avoided pronouncing general guidelines for "bad faith or improper behavior" in favor of making ad hoc calls. ${ }^{286}$ The courts that do define "bad faith or improper behavior" often do so in the negative and imply that the threshold is high: "Mere allegations that it appeared that the agency had a hostile attitude, or unwillingness to correct errors, or severity of action, or had a predetermined agenda, simply do not meet this standard."287 Nor do

281. Citizens to Pres. Overton Park, Inc. v. Volpe, 401 U.S. 402, 420 (1971), abrogated on other grounds by Califano v. Sanders, 430 U.S. 99 (1977).

282. See id. See also 5 U.S.C. $§ 706$ (2012); supra Section II.F.

283. Overton Park, 401 U.S. at 420.

284. Id. See also, Newton Cty. Wildlife Ass'n v. Rogers, 141 F.3d 803, 807 (8th Cir. 1998) ("When as here there is a contemporaneous administrative record and no need for additional explanation of the agency decision, 'there must be a strong showing of bad faith or improper behavior' before the reviewing court may permit discovery and evidentiary supplementation of the administrative record." (quoting Overton Park, 401 U.S. at 420)).

285. Cf. Univ. of Colo. Health at Mem'l Hosp. v. Burwell, 151 F. Supp. 3d 1, 12 (D.D.C. 2015) ("Reviewing 'less than the full administrative record,' might 'allow a party to withhold evidence unfavorable to its case,' while reviewing 'more than the information before the agency at the time of its decision,' risks 'requiring administrators to be prescient or allowing them to take advantage of post hoc rationalizations."' (quoting Walter O. Boswell Mem'l Hosp. v. Heckler, 749 F.2d 788, 792 (D.C. Cir. 1984))).

286. Tummino v. Von Eschenbach, 427 F. Supp. 2d 212, 230-32 (E.D.N.Y. 2006) (declaring, "What constitutes a strong preliminary showing of bad faith or improper behavior, however, is a matter that the courts have been reluctant to define, preferring in the main simply to declare that on the facts of a given case, the showing has not, or occasionally has, been made," before finding bad faith or improper behavior).

287. BECK, supra note 34, at 72 n.408 (citing James Madison Ltd. v. Ludwig, 82 F.3d 1085, 1095 (D.C. Cir. 1996)). See CACI, Inc. Fed. v. United States, 719 F.2d 1567, 1579-82 (Fed. Cir. 
mere allegations, however serious, that "have not been documented with the requisite degree of specificity," such as mere inferences from a hearing transcript. ${ }^{288}$ Neither errors in the initial compilation of an administrative record, later corrected, nor an inadvertent loss of some documents make for a "strong showing" that an agency is deliberately withholding pertinent documents. ${ }^{289}$ And according to Justices Gorsuch and Thomas, the necessary showing actually "requires an extraordinary justification," as it is leveled "against a coordinate branch of government." 290 In that case, "bad faith" does not exist simply because the decisionmaker takes office and seeks to implement views he held pre-appointment. ${ }^{291}$

However, the Court of Federal Claims has cautioned that "rare indeed would be the occasions when evidence of bad faith will be placed in an administrative record, and to insist on this - and thus restrict discovery regarding bad faith to cases involving officials who are both sinister and stupid-makes little sense."292 Bad faith was found, for example, when the petitioner pointed out the agency's "clearly hurried review process," its "effort to issue the decision before the change in Presidential Administrations," and "political pressure" from a Senate committee. ${ }^{293}$ The D.C. Circuit has suggested that impermissible bias includes congressional pressures. ${ }^{294}$

1983) (requiring "inferences of actual or potential wrongdoing" to be based on "hard facts," not "suspicion and innuendo"), superseded by statute, 40 U.S.C. § 3307 (2016).

288. San Luis Obispo Mothers for Peace v. Nuclear Reg. Comm'n, 751 F.2d 1287, 1327-29 (D.C. Cir. 1984) (citations omitted) ("The ease with which charges of 'bad faith' could be leveled, combined with the inordinate burden resolution of such claims would entail for courts, persuade us to decline petitioners' invitation to review the transcripts and to supplement the record. ... A great many parties could make similar accusations of impropriety in future litigation.... Courts do not have a limitless capacity to review documents in camera on the off-chance that something might turn up.... [Additionally,] over-eagerness by courts to review documents in camera and to supplement the administratively-created record fails to respect the autonomy of administrative agencies and the strong presumption that when administrative officials purport to decide weighty issues within their domain they have conscientiously considered the issues." (internal quotations marks omitted)), overruled on other grounds, 789 F.2d 26, 43-45 (D.C. Cir. 1986) (en banc).

289. TOMAC v. Norton, 193 F. Supp. 2d 182, 194 (D.D.C. 2002), aff'd, 433 F.3d 852 (D.C. Cir. 2006). But see Stand Up for Cal.! v. U.S. Dep't of Interior, 315 F. Supp. 3d 289, 296 (D.D.C. 2018) (permitting supplementation of the administrative record on grounds of bad faith where the petitioners made only a "prima facie case").

290. In re Dep't of Commerce, No. 18A375, 2018 WL 5259090, at *1 (U.S. Oct. 22, 2018) (Gorsuch, J., concurring in part and dissenting in part).

291. Id.

292. Beta Analytics Int'1, Inc. v. United States, 61 Fed. Cl. 223, 226 (2004). Although this case was not brought under the APA, the court's reasoning draws from an earlier Court of Federal Claims case that cites Overton Park. See Orion Int'l Techs. v. United States, 60 Fed. Cl. 338, 344 n.14 (2004).

293. Stand Up for Cal.!, 315 F. Supp. 3d at 296

294. D.C. Fed'n of Civic Ass'ns v. Volpe, 459 F.2d 1231, 1246 (D.C. Cir.) (“'An administra- 
Some courts interpret this bad faith exception overbroadly. One court said it was enough to show evidence merely "suggesting that the agency decision is arbitrary and capricious," in which case the agency is required to provide an explanation - thereby conflating a merits question with a record question. ${ }^{295}$ Such decisions raise problems because APA petitioners can easily acquire agency documents that they claim should have been part of the record by the Freedom of Information Act, ${ }^{296}$ the Privacy Act, ${ }^{297}$ or other means. These enterprising individuals can then use these documents to press a claim of bad faith. ${ }^{298}$

This doctrine is sometimes imprecisely employed as a freestanding supplementation ground. Consequently, if bad faith is shown, petitioners are apparently free to conduct discovery of unclear scope, perhaps not even related to the matters about which the agency acted in bad faith. ${ }^{299}$ Other courts permit supplementation only if the proffered supplementary materials themselves are probative of bad faith, which presumably are relevant to the merits question of whether the agency acted arbitrarily or capriciously. ${ }^{300}$ Given the divergent manners in which courts interpret this Overton Park dicta, there is no clear distinction upon which to segregate bad faith and improper behavior into two separate bases.

The "bad faith and improper behavior" doctrine is untenable be-

tive adjudication] would be invalid if based in whole or in part on the [congressional] pressures."). See Schaghticoke Tribal Nation v. Kempthorne, 587 F. Supp. 2d 389, 409-10 (D. Conn. 2008); Stand Up for Cal.!, 315 F. Supp. 3d at 296.

295. Impresa Construzioni Geom. Domenico Garufi v. United States, 238 F.3d 1324, 1338 (Fed. Cir. 2001); see also Nat. Res. Def. Council, Inc. v. SEC, 606 F.2d 1031, 1049 n.23 (D.C. Cir. 1979) (citations omitted) ("[T]he presumption of agency regularity is rebutted, as where the agency has demonstrated undue bias towards particular private interests; where the agency has had a history of ad hoc and inconsistent judgments on a particular question; where the agency has arrived at an identical result after remand from a reviewing court for further explanation of reasons; or when an agency has departed from its consistent and longstanding precedents or policies.").

296. 5 U.S.C. $\S 552$ (2012). See, e.g., Outdoor Amusement Bus. Ass'n v. Dep’t of Homeland Sec., No. ELH-16-1015, 2017 WL 3189446, at*11 (D. Md. July 27, 2017). Such use of the Freedom of Information Act is unsurprising because that law is a subpart of the APA.

297. 5 U.S.C. § 552a (2012).

298. E.g., Outdoor Amusement Bus. Ass'n, 2017 WL 3189446, at *6, *20-22 (plaintiff's counsel using FOIA returns to allege bad faith withholding of documents properly in the record).

299. E.g., Tri-Valley CARES v. U.S. Dep't of Energy, 671 F.3d 1113, 1130 (9th Cir. 2012); Town of Winthrop v. FAA, 535 F.3d 1, 14 (1st Cir. 2008); Sierra Club v. Slater, 120 F.3d 623, 63839 (6th Cir. 1997). But see Getty Oil Co. v. U.S. Dep't of Energy, No. CV 77-4533, 1979 WL 1029, at *2 (C.D. Cal. May 16, 1979) ("[T] his Court does not believe that discovery can be utilized to find evidence of bad faith or improper behavior. If discovery could be utilized for that purpose, it would allow extensive probing into the internal agency documents on the mere allegation of bad faith. Such a ruling would undermine the clear intent of the Overton Park decision.").

300. ARKRAY USA, Inc. v. United States, No. 14-233C, 2014 WL 2905127, at*4 (Fed. Cl. Apr. 28, 2014) ("Supplementation may be appropriate ... where the additional evidence is likely probative of potential agency bias or bad faith.” (citations omitted)). 
cause, like much of APA record jurisprudence, it conflates the record with the merits. If an agency acts in bad faith or behaves improperly, and the improper conduct is reflected in the record already, then supplementing the record is unnecessary. The court can determine from the existing administrative record whether the behavior was unlawful under the appropriate APA standard. For example, if the alleged bad faith is the agency succumbing to political pressure, then the court has all relevant documents necessary to determine whether that pressure caused the agency to act "arbitrar[ily]" or "capricious[ly]."301

If the agency acts in bad faith or behaves improperly, and the improper conduct is not in the record presented, the question becomes whether the agency truly relied on its improper motivations. If so, then that material is properly part of the record, and the administrative record is subject to completion. The court can proceed by assessing the record as presented and determining whether the agency action can be upheld on the stated basis, acknowledging 5 U.S.C. $§ 706$ 's allowance of harmless error. ${ }^{302}$ Making a decision based solely on improper reasons is the very definition of capricious. But if the agency did not rely on those bad-faith or improper motivations, its evidence does not belong in the record, and should not be used to "complete" the existing administrative record. One court has come close to recognizing this. ${ }^{303}$

Another inappropriate class of information that should not be added to the record is oral communication. One court described oral inputs (or as it has also been deemed, "verbal inputs") as "relevant information that by its very nature would not be found in an agency record-such as . . . the content of conversations." ${ }^{304}$ Including oral communications in the

301. 5 U.S.C. $\S 706(2)(A)(2012)$.

302. 5 U.S.C. $§ 706$ ("In [reviewing agency action,] due account shall be taken of the rule of prejudicial error.").

303. Latecoere Int'l, Inc. v. U.S. Dep't of Navy, 19 F.3d 1342, 1356-57 (11th Cir. 1994) (stating that "proof of subjective bad faith by procuring officials, depriving a bidder of fair and honest consideration of its proposal, generally constitutes arbitrary and capricious action," in an APA contract-bid dispute, but ultimately concluding that the finding of bad faith permitted record supplementation).

304. Orion Int'l Techs. v. United States, 60 Fed. Cl. 338, 343-44 (2004). In the DACA case before the Supreme Court, the district judge - the nominal respondent in the petition for a stay pending disposition of the petition for a writ of certiorari-filed a statement with the Supreme Court defending his order for the U.S. Government to include evidence concerning oral advice relied upon by the decisionmaker (or, in the district judge's parlance, "verbal inputs"). Statement of Dist. Court in Response to Application for a Stay, No. 17A570 at 4, (Dec. 5, 2017) https://www.supremecourt.gov/DocketPDF/17/17-801/22797/20171206145957950_17A570\%20In \%20Re\%20United\%20States\%20Response\%20NDCA.pdf [https://perma.cc/W9J3-LP3W]. The district judge acknowledged that "[t]he Supreme Court has never considered how, if at all, verbal inputs to an agency decisionmaker should be reflected in the administrative record." Id. Neverthe- 
record is incorrect, because although virtually no cases have had squarely addressed the issue, most cases define "the whole record" as a function of documents and other tangible materials. ${ }^{305}$ The order in that case essentially created a second-degree administrative record, where the agency had to furnish all materials considered by individuals who in turn provided oral consultation with the decisionmaker, regardless of whether the intermediaries relied on the materials when providing advice. This chain expands the administrative record beyond the strictures of the APA and Supreme Court cases like Camp v. Pitts. ${ }^{306}$ Requiring agencies to memorialize, after the fact, any oral conversations would also impose a tremendous burden on the agencies. It is difficult for agencies to assess with certainty which employees provided oral input to decisionmakers, and to then reconstruct the content of such input.

Further afield from the APA's "whole record" anti-discovery regime is the concept of record supplementation. Supplementation is categorically impermissible because an APA court reviews only the record before the agency at the time it made its decision. Therefore, information that is developed and presented to the agency after the agency makes its final action is outside the scope of APA review, post hoc under Chenery $I,{ }^{307}$ and irrelevant in contravention of the discovery rules. ${ }^{308}$ Consistent with those principles, the Court in Overton Park refused to look at the

less, using both the Ninth Circuit's statement that the administrative record comprises all "documents considered directly or indirectly" and the Court of Federal Claims' permission for a party to depose an agency employee after credibly alleging agency bias, the district judge concluded that "[t]here is no clear and indisputable right to omit all evidence of verbal inputs to the agency decisionmaker." (emphasis added) Id. Finding that the agency decisionmaker had received oral advice on DACA, but that "[s]uch verbal inputs ... were not captured by the government's administrative record," the district judge "attempted to cure this omission by requiring inclusion of all DACArelated materials received by those providing any verbal inputs, at least up to the point of their input." Id.

305. See, e.g., Bar MK Ranches v. Yuetter, 994 F.2d 735, 739 (10th Cir. 1993) (defining an administrative record as "all documents and materials directly or indirectly considered by the agency") (emphasis added); James Madison Ltd. ex rel. Hecht v. Ludwig, 82 F.3d 1085, 1095 (D.C. Cir. 1996) (stating similar language); Sierra Club v. Slater, 120 F.3d 623, 638 (6th Cir. 1997) (stating similar language); Thompson v. U.S. Dep't of Labor, 885 F.2d 551, 555 (9th Cir. 1989) (stating " "[t]he whole administrative record ... consists of all documents and materials directly or indirectly considered by agency decision-makers and includes evidence contrary to the agency's position." (quoting Exxon Corp. v. Dep't of Energy, 91 F.R.D 26, 33 (N.D. Tex 1981))).

306. 411 U.S. 138, 142 (1973) ("[T]he focal point for judicial review should be the administrative record already in existence, not some new record made initially in the reviewing court.").

307. See supra Section II.E. But see Action on Smoking \& Health v. Civil Aeronautics Bd., 713 F.2d 795, 799 n.2 (D.C. Cir. 1983) ("Where, as in Camp ... , the agency's explanation is required to be responsive to the purposes of the enabling statute, rather than to a record developed through mandatory hearings or public comments, post hoc explanations, while undesirable, are not fatal.").

308. FED. R. CIV. P. 26(b)(1). 
agency's extra materials created after litigation. ${ }^{309}$

Despite this indeterminate and inconsistent language, one statute does suggest that supplementation may be permissible. The Superfund statute explicitly states:

[i]n any judicial action under this chapter, judicial review of any issues concerning the adequacy of any response action taken or ordered by the President shall be limited to the administrative record. Otherwise applicable principles of administrative law shall govern whether any supplemental materials may be considered by the court. ${ }^{310}$

This implies that there are some principles of administrative law that permit supplementation. ${ }^{311}$ However, this may also mean that Congress used sloppy terminology here-as courts often do-and simply meant "completion." In any event, this statute is not part of the APA.

Courts vary widely on the showing necessary to rebut the presumption of administrative regularity in compiling an administrative record and to thereby permit supplementation. The petitioner "bears the burden of explaining why the agency-assembled administrative record is insufficient," 312 consistent with the presumption of agency regularity. But given the confusion in this realm, that burden varies in size. As alluded to earlier, some courts require a "strong showing of bad faith or improper behavior." 313 Other courts speak of "clear evidence",314 or "concrete evidence." "315 Others want to see "well grounded allegations" of bad faith or improper behavior, which is something less than "clear and convincing evidence." "316 Some courts demand "unusual circumstances" to justify a departure from the general presumption. ${ }^{317}$ One court asked only for

309. See supra notes $127,128,178$, and accompanying text.

310. 42 U.S.C. $§ 9613(j)(1)$ (2012) (emphasis added).

311. E.g., United States v. Akzo Coatings of Am., Inc., 949 F.2d 1409, 1427-28 (6th Cir. 1991) (examining $\S 9613(\mathrm{j})(1)$ and holding that, as part of those "[o]therwise applicable principles of administrative law," the district court should have permitted supplementation of the administrative record); United States v. P.H. Glatfelter Co., 768 F.3d 662, 669 (7th Cir. 2014) (same).

312. DataMill, Inc. v. United States, 91 Fed. Cl. 722, 732 (2010).

313. This standard, of course, was developed in the completion context for Overton Park. E.g., Iowa League of Cities v. EPA, 711 F.3d 844, 864 n.13 (8th Cir. 2013); Town of Winthrop v. FAA, 535 F.3d 1, 14 (1st Cir. 2008).

314. E.g., Pac. Shores Subdivision, Cal. Water Dist. v. U.S. Army Corps of Eng'rs, 448 F. Supp. 2d 1, 5 (D.D.C. 2006).

315. E.g., Pub. Emps. for Envtl. Responsibility v. Beaudreau, Civil Action No. 10-1067, 2012 WL 12942599, at*4 (D.D.C. Nov. 9, 2012).

316. L-3 Comm. Integrated Sys., L.P. v. United States, 91 Fed. Cl. 347, 354 (2010), amended in part, 98 Fed. Cl. 45 (2011); Pitney Bowes Gov't Sols., Inc. v. United States, 93 Fed. Cl. 327, 334 (2010).

317. E.g., Medina Cty. Envtl. Action Ass'n v. Surface Transp. Bd., 602 F.3d 687, 706 (5th Cir. 
"probabilistic showing that discovery is sufficiently likely to unearth evidence relevant to deciding whether the record should be [completed]." ${ }^{318}$ Finally, the mere size of the record may play some unspecified role in deciding whether to permit discovery or supplementation. ${ }^{319}$

Supplementation comes in many forms that vary depending on the circuit and the district. First, courts permit supplementation if the agency provided only a "bare record." 320 That language does come from Overton Park, but the decision was not about how the exception works. Overton Park said that because the record was "bare," the record "may not disclose the factors that were considered," so it "may be necessary" for the district court to receive additional materials. ${ }^{321}$ The premise of the bare-record exception is that there are certain factors that should be considered, but that the record does not confirm were considered.

But this exception fundamentally confused the merits of the case with the evidence needed to prove it. If, for example, the record appears to reference certain materials that are not in it and the court cannot confirm that the materials were considered, then the record would fall under the demonstrably-incomplete exception and the case should be remanded for completion of the record. If the record does not contain a coherent agency decision and the court cannot confirm how the data relates to the final decision, then the agency action should fail on the merits, just like in the important Supreme Court case of Motor Vehicle Manufacturers Ass' $n$ v. State Farm. ${ }^{322}$ The proper course is to remand for completion of the record or for a new decision, permitting the agency to properly consider the factors.

Perhaps the "bare record" route to supplementation means that the

2010) (citing Am. Wildlands v. Kempthorne, 530 F.3d 991, 1002 (D.C. Cir. 2008)); see also Motor \& Equip. Mfrs. Ass'n, Inc. v. EPA, 627 F.2d 1095, 1104 n.18 (D.C. Cir. 1979) (“[S]upplementation of the [administrative] record ... decidedly is the exception not the rule.").

318. La Union del Pueblo Entero v. FEMA, 141 F. Supp. 3d 681, 695 (S.D. Tex. 2015).

319. NVE, Inc. v. HHS, 436 F.3d 182, 196 (3d Cir. 2006) (agreeing with the district court's decision to decline discovery).

320. Citizens to Pres. Overton Park, Inc. v. Volpe, 401 U.S. 402, 420 (1971), abrogated on other grounds by Califano v. Sanders, 430 U.S. 99 (1977); Little Co. of Mary Hosp. v. Sebelius, 587 F.3d 849, 856 (7th Cir. 2009) (referring to the exception as "[where] necessary to create a record without which the challenge to the agency's action cannot be evaluated," though noting it will be rarely applied, and affirming the district court for refusing to do so in this case); Sierra Club v. U.S. Dep't of Energy, 26 F. Supp. 2d 1268, 1271 (D. Colo. 1998) (suggesting that a court could review "past conduct of the agency, to determine whether an agency unlawfully withheld action required by law."); see also, supra Section III.D.

321. Overton Park, 401 U.S. at 420.

322. See Motor Vehicle Mfrs. Ass'n v. State Farm, 463 U.S. 29, 43 (1983) (holding that courts must determine whether the agency has examined all relevant data and articulated a sufficient connection between the data and its decision). 
agency necessarily but silently considered factors not apparent from the record. If so, the "bare record" ground is paradoxical. A court cannot know whether the agency considered factors outside the record unless it looks outside the record to see what those factors were and compares them to the record. That constitutes a merits inquiry. Overton Park defined an arbitrary or capricious agency action as a failure to consider all relevant factors - the central question of a merits inquiry in a 5 U.S.C. $\S 706(2)$ action. Thus, a merits inquiry would rebut the presumption of regularity if the "bare record" actually means a "demonstrably incomplete" or "null" record, but only to permit completion of the record.

To do otherwise would invite tension with Chenery I and impose unreasonable burdens on the agency by forcing it to write merits decisions that excruciatingly assess every single material considered, even when a court should fairly assume that a piece of evidence was considered but rejected or accepted. ${ }^{323}$ The reality is, however, that this is a tempting route for a court to take, especially one not versed in the subject matter being reviewed, not confronted with advocates familiar with the contours of APA record review, or presiding over a 5 U.S.C. $§ 706(1)$ unreasonable delay case. ${ }^{324}$

Second, some courts order supplementation to determine whether the agency considered all relevant factors and adequately explained its decision. ${ }^{325}$ This exception has been described more expansively as needed "when it is necessary for a full and complete understanding of the issues." 326 This exception, however, should not be entertained for the reasons discussed above as a "bare record" justification. ${ }^{327}$

323. Cf. Kurshumi v. Ashcroft, 102 F. App'x 172, 175 (1st Cir. 2004) ("The [Board of Immigration Appeals] is not required to discuss each and every piece of evidence or write an exegesis on every contention.”); Cablevision Sys. Corp. v. FCC, 570 F.3d 83, 92 (2d Cir. 2009) (“An administrative agency has a duty to explain its ultimate action. ... However, it need not explain each and every step leading to this decision ... [the agency need not] sift through each piece of evidence offered by a party and explain why it is more or less compelling than the counter-evidence put forth by an opponent."); Craig v. Apfel, 212 F.3d 433, 436 (8th Cir. 2000) (“Although required to develop the record fully and fairly, an ALJ is not required to discuss all the evidence submitted, and an ALJ's failure to cite specific evidence does not indicate that it was not considered.").

324. See, e.g., Sierra Club, 26 F. Supp. 2d at 1271; Raymond Proffitt Found. v. Army Corps of Eng'rs, 128 F. Supp. 2d 762, 768 n.8 (E.D. Pa. 2000).

325. BECK, supra note 35, at 67; see Yale-New Haven Hosp. v. Leavitt, 470 F.3d 71, 82 (2d Cir. 2006) (cautioning that the explanation "should contain no new rationalizations").

326. Blue \& Gold Fleet, LP v. United States, 70 Fed. Cl. 487, 494 (2006), aff'd, 492 F.3d 1308 (Fed. Cir. 2007).

327. Cf. Sierra Club v. Marsh, 976 F.2d 763, 773 (1st Cir. 1992) ("If the agency action, once explained by the proper agency official, is not sustainable on the record itself, the proper judicial approach has been to vacate the action and to remand ... to the agency for further consideration."); Friends of Payette v. Horseshoe Bend Hydroelectric Co., 988 F.2d 989, 997 (9th Cir. 1993); Envtl. Def. Fund, Inc. v. Costle, 657 F.2d 275, 285 (D.C. Cir. 1981). 
Third, courts permit parties to supplement the administrative record with "background information" where "the agency failed to (a) explain administrative action so as to frustrate judicial review, or (b) explain technical terms or complex subjects." 328 Such supplementation is contrary to the APA. While it might sound innocent, "background information" is indeterminate and opens the door to substantive consideration. ${ }^{329}$ If an agency action is impenetrable to a district judge because the judge lacks fluency in the complex subject matter at issue, there are two other ways the matter could be explained to the judge. The parties could supplement the record by joint stipulation to ensure the judge's comprehension of the case. The judge could also take judicial notice of background information, consistent with the Federal Rules of Evidence. Such evidence would then be assured to be relatively neutral. Otherwise, if the agency action is rationalized in a manner too confusing for the judge to determine that it was unlawful, then the petitioners have necessarily failed their burden. ${ }^{330}$

Fourth, courts often want to see information supporting "predictive judgments." 331 Often agencies take some action based on their informed judgments that something may or may not occur in the future. Up to six years may pass before such agency action is challenged in court, given the statute of limitations. ${ }^{332}$ In that timeframe, the parties may be able to see whether the agency's predictions were correct. If the agency's predictions were incorrect, an unhappy individual may want to use evidence of incorrect prediction in an effort to demonstrate that the agency's antecedent action was unlawful. For that purpose, federal courts sometimes permit supplementation of the administrative record with evidence that "c[a]me into existence after the agency acted that demonstrates that the agency's actions were right or wrong." ${ }^{333}$ This exception is improper, however, as it is violates the APA "whole record" rule without any countervailing policy benefits. A federal court abets impermissible post hoc rationalization by considering this information as part of a supplemented administrative record. Agencies should be able to exercise the latitude

328. BECK, supra note 35, at 67; see, e.g., Copar Pumice Co. v. Tidwell, 603 F.3d 780, 791 n.3 (10th Cir. 2010); DataMill, Inc. v. United States, 91 Fed. Cl. 722, 730 (2010).

329. But see Yale-New Haven Hosp., 470 F.3d at 82 (trusting courts to not consider any explanatory supplementation as part of the merits).

330. See supra note 172 .

331. BECK, supra note 35 , at 71 .

332. See 28 U.S.C. § 2401(a) (2012) (setting the APA statute of limitations).

333. BECK, supra note 35, at 71. The D.C. Circuit reviews predictive judgments even more favorably, see Edison Elec. Inst. v. OSHA, 849 F.2d 611, 618 (D.C. Cir. 1988); Nat'l Tel. Coop. Ass'n v. FCC, 563 F.3d 536, 541 (D.C. Cir. 2009). 
given to them by Congress to issue predictive judgments without later second-guessing by affected parties whose real quarrel lies with the outcome, not the prediction.

Fifth, some courts grant motions to supplement the administrative record in cases challenging agency inaction. ${ }^{334}$ There is a record in these cases: the materials that the agency relied on in consciously or unconsciously failing to act. ${ }^{335}$ Further, the APA in 5 U.S.C. $\$ 706$ contemplates a record for failure-to-act cases, as it states, "In making the foregoing determinations, [that is, under $\S 706(1)$ and (2),] the court shall review the whole record...., ${ }^{336}$ Because there is already a defined scope for "the whole record," this category of information is misclassified as game for supplementation. ${ }^{337}$ Agency action that is a failure to act should not be treated differently than any other type of agency action.

Finally, some courts have found supplementation permissible upon only the petitioner's belief (whether founded or not) that evidence not before the agency should have been considered by the agency. ${ }^{338}$ Of the record supplementation grounds, this one is the least compatible with the APA record rule, as it seems to permit discovery merely upon petitioners disagreeing with the result of an agency action. It has no apparent connection with the text, structure, purpose, or legislative history of that law. Like the other grounds of supplementation discussed above, courts should stop permitting APA petitioners to pursue it.

334. Esch v. Yeutter, 876 F.2d 976, 991 (D.C. Cir. 1989) (recognizing "where agencies are sued for a failure to take action" as an exception to the general rule against supplementation); Friends of the Clearwater v. Dombeck, 222 F.3d 552, 560 (9th Cir. 2000) ("[In § 706(1) cases,] review is not limited to the record as it existed at any single point in time, because there is no final agency action to demarcate the limits of the record.").

335. See, e.g., Sierra Club v. U.S. Dep't of Energy, 26 F. Supp. 2d 1268, 1271 (D. Colo. 1998).

336. 5 U.S.C. $\$ 706(2012)$.

337. Young, supra note 120, at 224 ("To the extent, however, that an agency's refusal to hold such a proceeding is reviewable, there is a record on which the agency based its decision not to commence such a proceeding. Analogously to Overton Park, the record is everything the agency actually considered or was required to consider in deciding not to start an adjudication or rulemaking.").

338. Citizens for Alts. to Radioactive Dumping v. U.S. Dep't of Energy, 485 F.3d 1091, 1096 (10th Cir. 2007) ("In dealing with scientific and technical evidence, extra-record evidence may illuminate whether an [environmental impact statement] has neglected to mention a serious environmental consequence, failed adequately to discuss some reasonable alternative, or otherwise swept stubborn problems or serious criticism ... under the rug." (internal quotation marks omitted)); Oceana, Inc. v. Pritzker, 217 F. Supp. 3d 310, 316 (D.D.C. 2016) ("[A] party may request the disclosure of extrajudicial evidence that was not initially before the agency but the party believes should nonetheless be included in the administrative record." (citations omitted)). 


\section{E. How to Complete the Record}

When an APA petitioner identifies a class of documents that properly belongs in "the whole record," it must consider the procedure for objecting to the documents' absence from the record. The first step is for the petitioner to examine the record once the agency furnishes it. Recall that the record is rarely compiled and maintained contemporaneous with the agency's action or inaction; agencies often need time to produce the record. Different courts require the agency to furnish the record at different points in litigation. ${ }^{339}$ Some require the record to be filed and specify timelines. ${ }^{340}$ Others require the record to be filed, but specify no timeline. ${ }^{341}$ Others make no mention of when the record should be served on the other party or whether it must be filed. ${ }^{342}$ Others require only an index of the record to be filed. ${ }^{343}$ An agency is not required to file a certification, ${ }^{344}$ though a certification may buttress the presumption

339. Some courts impose these requirements through local rules; other times, individual judges may impose these requirements through standing orders or through ad hoc scheduling orders. See, e.g., D. AlASKA L.R. 16.3(b)(1) (requiring the record to be filed within 60 days after the defendants appear); D. KAN. L.R. 83.7.1(c)(1) (requiring the record to be filed contemporaneously with the defendants' answer, which will be 60 days after the defendants appear); D. AK. L.R. 16.3(b)(1) (requiring the agency to file the record within 60 days after the defendants appear); N.D. CAL. CIVIL L.R. 16-5 (requiring the "a certified copy of the transcript of the administrative record" to filed within 90 days after the defendants appear); see also Valentini v. Shinseki, CV 11-4846 SJO (MRWx), 2013 WL 12120074 (C.D. Cal. Jan. 22, 2013).

340. W.D. WASH. LCR 79(h) (requiring the agency to file the record within thirty days of filing the complaint if the agency is the plaintiff, or with the answer if the agency is the defendant); D. UTAH DUCIVR 7-4 (establishing a whole regime of APA-specific case procedures). See also FED. R. CIV. P. 26(d)(1) (setting the general rule that parties cannot seek discovery before the parties have had the Rule 26(f) conference, "except in a proceeding exempted from initial disclosure under Rule 26(a)(1)(B)," such as review of agency action).

341. D. OR. LR 5-2(e).

342. E.g., W.D. Mo. L.R. 5.1 (requiring all represented parties must file documents electronically, but not specifying which documents an agency must file or a time period in which they must be filed).

343. D.D.C. LCVR 7(n) (requiring agency counsel to first file a certified list of the record's contents but prohibiting the agency from filing the entire record unless ordered by the court).

344. "Although the Department of Health and Human Services (HHS), like many other federal agencies, files certifications with administrative records as a matter of practice, certifications are not required by the APA or any other law. Plaintiffs have cited no authority suggesting otherwise and in fact expressly acknowledge in their briefing that courts in this district have held that 'there is no legal authority compelling the defendants to certify an administrative record in the first instance." Banner Health v. Sebelius, 945 F. Supp. 2d 1, 18 (D.D.C. 2013) (citing Cty. of San Miguel v. Kempthorne, 587 F. Supp. 2d 64, 77 (D.D.C. 2008), vacated in part on other grounds, No. CV 1001638, 2013 WL 11241368 (D.D.C. July 30, 2013); Ravulapalli v. Napolitano, 840 F. Supp. 2d 200, 206 (D.D.C. 2012) ("The lack of certification, without more, certainly does not rise to the level of 'clear evidence' necessary to overcome the presumption of regularity.") (citations omitted); Outdoor Amusement Bus. Ass'n v. Dep't of Homeland Sec., No. CV ELH-16-1015, 2017 WL 3189446, at *5, *9-11 (D. Md. July 27, 2017) (rejecting an argument that the agency was required to submit a certification that established, among other things, that the relevant agency official had actually con- 
of agency regularity. ${ }^{345}$

Courts should not look into the record until threshold jurisdictional defenses are adjudicated, even if the merits dispute is urgent or important. $^{346}$ If a court does not have specialized rules for APA proceedings, ${ }^{347}$ then the court should not require the record to be furnished until after the pleadings close. ${ }^{348}$

Even if the petitioner believes that "completion" material should be restored to the administrative or judicial record, the agency must have the opportunity to bring jurisdictional defenses in Rule 12(b)(1) and (2) motions to dismiss to pretermit the possibility of unnecessarily compiling, furnishing, and engaging the record. ${ }^{349}$ Petitioners should also have to surmount the bar of Rule $8(a)(2),{ }^{350}$ which is trans-substantive, and demonstrate that their APA complaint states a claim upon which relief can be granted. Many courts are split as to whether APA complaints are subject to motions to dismiss on pleading and merits grounds. ${ }^{351}$ While

sidered the record; it is full or complete; and it existed at the time of the decision.) (internal citations and quotation marks omitted). Some organic statutes require the filing of a certified administrative record. E.g., 42 U.S.C. $\S \S 405 I, 1383$ (c)(3) (2012) (regarding Social Security).

345. Stainback v. Winters, 520 F. Supp. 2d 181, 188 (D.D.C. 2007). One court, to resolve a dispute over the record's completeness, ordered the agency "to affirm under oath that the Record is complete so that this matter may proceed to resolution." Buckingham Twp. v. Wykle, No. CIV. A 99-621, 2000 WL 233474, at *2 (E.D. Pa. Feb. 28, 2000).

346. In re United States, 138 S. Ct. 443, 445 (2017).

347. See, e.g., D. UTAH DUCIVR 7-4 (establishing a regime of APA-specific case procedures); see also D. KAN. L.R. 83.7.1 (also establishing a regime of APA-specific case procedures); N.D. IOWA \& S.D. IOWA L.R. 16(h) (requiring the attorneys to confer and file a "proposed scheduling order setting forth deadlines for the filing of the administrative record and briefs.").

348. Some organic statutes lay out a separate timeline for record filing. For instance, in Social Security appeals challenging the denial of Title II disability insurance benefits or Title XI supplemental security income benefits, the certified record must be filed as "part of" the Commissioner's answer. 42 U.S.C. $\S \S 405(\mathrm{~g}), 1383(\mathrm{c})(3)(2012)$. The above suggestion would apply only in the absence of an organic statute on point.

349. FED. R. CIV. P. 12(b)(1)-(2); see In re United States, 138 S. Ct. 443; Coal. for Underground Expansion v. Mineta, 333 F.3d 193, 198 (D.C. Cir. 2003).

350. FED. R. CIV. P. 8(a)(2).

351. Id.; Compare, e.g., Shashlov v. Sessions, No. 17-cv-2166, 2017 WL 6496440 (C.D. Cal. Dec. 4, 2017) (dismissing an APA challenge without leave to amend for failure to state a claim even though the record had not been served or filed), with Atieh v. Riordan, 727 F.3d 73, 75 (1st Cir. 2013) (reversing a district court's Rule 12(b)(6) dismissal of an APA action, arguing that given the Overton Park standard of review, the Twombly plausibility standard "does not apply" in an APA case and "a court should not be required to guess at whether or not it has the complete administrative record") and Pitman v. USCIS, Case No. 2:17-cv-166, 2017 WL 5991738, at *2 (D. Utah Dec. 1, 2017) ('Rather than rely on Defendants' assertions of what was in the record or Plaintiffs' alleged concessions, the court must undertake its own review of the administrative record as a whole."). Failing to allow Rule 8(a)(2) and Rule 12(b)(1)-(2) motions appears to neuter the provision of $\S 706$ that establishes the object of review as the "the whole record or those parts of it cited by a party." United States v. Menendez, 48 F.3d 1401, 1409 (5th Cir. 1995) (holding that that phrase did not obviate the government's obligation to furnish the record because under 5 U.S.C. $\S 559$, the APA does 
these motions are pending, a petitioner might be able to obtain discovery on a limited, discrete topic such as irreparable harm for preliminary injunction purposes,${ }^{352}$ but that discovery should not bleed into the merits and become impermissible record supplementation.

After surviving Rule 12, petitioners can use the summary-judgment mechanism of Rule $56 .{ }^{353}$ It should be irrelevant if the district practice is to call the filing a Rule 12(c) motion for judgment on the pleadings or a "motion to set aside," to require the parties to simply file "briefs," 354 or to treat the initial pleading as a dispositive motion in and of itself, so long as the timing rules are observed. That is, courts should not require the record to be furnished until the agency has had a chance to lodge threshold defenses with no traditional discovery in the meantime. Nevertheless, some districts specify that the appropriate vehicle for resolving the merits of an APA dispute is cross-motions for summary judgment under Rule 56.

For preliminary injunctive relief or a temporary restraining order under Rule 65, the usual rule likely applies: a party is not expected to prove its whole case on a Rule 65 motion. ${ }^{355}$ A party might be able to obtain expedited discovery in advance of a preliminary injunction hearing, perhaps to address issues collateral to the record such as irreparable harm and the balance of the equities. ${ }^{356}$ However, this discovery should not supplement the record, and thus should not be considered in the merits

not limit the additional requirements imposed by other statutes, and that case featured additional requirements imposed by the Endangered Species Act).

352. In re United States, 138 S. Ct. 443; Coal. for Underground Expansion, 333 F.3d at 198; Pennsylvania v. Trump, Civil Action No. 17-4540, 281 F. Supp. 3d 553 (E.D. Pa. 2017) (permitting evidence from outside the administrative record to demonstrate irreparable harm, the public interest, and the balance of equities, among other exceptions) appeal filed, Feb. 15, 2018.

353. FED. R. CIV. P. 56(d); see, e.g., D. ALASKA LR 16.3(c) (requiring an APA plaintiff to file a motion for summary judgment within 30 days after the agency record is filed).

354. See, e.g., D. KAN. L.R. 83.7.1(d) (requiring an APA plaintiff to file a "brief" within fortyfive days after the agency record is filed); D. UTAH DUCIVR 7-4 (establishing a whole regime of APA-specific case procedures).

355. FED. R. CIV. P. 65; Univ. of Tex. v. Camenisch, 451 U.S. 390, 395 (1981) (citations omitted) (" $[\mathrm{A}]$ preliminary injunction is customarily granted on the basis of procedures that are less formal and evidence that is less complete than in a trial on the merits. A party thus is not required to prove his case in full at a preliminary-injunction hearing, and the findings of fact and conclusions of law made by a court granting a preliminary injunction are not binding at trial on the merits.").

356. E.g., Unified Gov't of Wyandotte Cty./Kan. City v. U.S. Gen. Servs. Admin., No. 112400, 2012 WL 602838, at*2 (D. Kan. Feb. 24, 2012) (acknowledging that some issues raised by a preliminary injunction motion, such as irreparable injury and the balance of harm, "are not likely to be addressed in an agency's administrative record," thus "under certain circumstances, some limited discovery might be appropriate to clarify the harm a party might suffer if an injunction were entered," but finding it unnecessary in that case); Meritain Health Inc. v. Express Scripts, Inc., No. 4:12-CV-266, 2012 WL 1320147, at *3 (E.D. Mo. Apr. 17, 2012) (discussing, in a non-APA context, the standards for granting expedited discovery in advance of a preliminary injunction hearing). 
inquiry. ${ }^{357}$

If a petitioner wants completion of the record, then he or she can file a motion styled to that effect. Agencies should be able to file a motion for a protective order barring impermissible discovery, ${ }^{358}$ especially if discovery would force the disclosure of sensitive information carefully restricted by federal law, ${ }^{359}$ or if the record includes material that does not rise to the level of privilege, but is sensitive nonetheless (for example, it is law-enforcement sensitive). ${ }^{360}$

\section{F. Remedies for Difficult Completion}

If a court finds that the record is incomplete and the agency cannot easily provide the missing information, then the remedy should be for the court to remand to the agency to reformat the administrative record it submits for judicial review. The remedy should not be discovery into whether the record is complete.

Discovery is inappropriate in this situation because nothing in the Overton Park line of Supreme Court cases endorses discovery. At most, a district court may hold a hearing after it finds the agency has not presented the court with the complete record before the agency at the time it made its decision. ${ }^{361}$ In Overton Park, a hearing in district court was the remedy ordered because the agency had egregiously failed to produce any record in litigation and it likely would be unable to do so. ${ }^{362}$ But even then, the optimal course of action is to remand to the agency, where additional facts can be added to the record in the ordinary course of agency business. ${ }^{363}$

This remedy also works in "blended" cases where the court is unable

357. Nat'l Ass'n of Mortg. Brokers v. Bd. of Governors of Fed. Reserve Sys., 770 F. Supp. 2d 283, 288-89 (D.D.C. 2011) (granting a petitioner's motion for expedited discovery in advance of filing a preliminary injunction motion, but only ordering the agency to produce the administrative record on an expedited basis, given the rule barring discovery in APA lawsuits).

358. E.g., Harvard Pilgrim Health Care of New Eng. v. Thompson, 318 F. Supp. 2d 1, 3, 13 (D.R.I. 2004).

359. E.g., 8 U.S.C. $\S 1367$ (2012 \& Supp. V 2017) (information relating to asylum applications).

360. See Jifry v. FAA, 370 F.3d 1174, 1182 (D.C. Cir. 2004) (relying on "law enforcement sensitive" information in determining whether to set aside agency action under the APA).

361. See supra Section II.F.

362. Citizens to Pres. Overton Park, Inc. v. Volpe, 401 U.S. 402, 420 (1971); abrogated on other grounds by Califano v. Sanders, 430 U.S. 99 (1977).

363. See Camp v. Pitts, 411 U.S. 138, 143 (1973) (remanding to obtain information from agency additional explanation for its decision); Christopher J. Walker, The Ordinary Remand Rule and the Judicial Toolbox for Agency Dialogue, 82 GEO. WASH. L. REV. 1553 (2014). 
to discern whether the agency decision satisfies the substantive standard of review, either because the agency's record is deficient or the agency's decision-making is deficient. We argue this is the "bare record" problem Overton Park incorrectly identified as purely a records problem. ${ }^{364}$ If a court cannot conduct the appropriate review on the merits of the administrative record presented, then the court should grant the APA review petition per 5 U.S.C. $\S 706(1)^{365}$ or per $\S 706(2)$, ${ }^{366}$ and remand so the agency can reformat its decision after it is set aside by the court. ${ }^{367}$ This is the usual remedy when the merits, not the record, are at issue $\mathrm{e}^{368}$ : the "reme-

364. Overton Park, 401 U.S. at 420.

365. 5 U.S.C. § 706(1) (allowing courts to compel agency action that is "unlawfully withheld or unreasonably delayed").

366. 5 U.S.C. $§ 706(2)$ (2012) (allowing courts to "hold unlawful and set aside" agency action meeting the statutory criteria).

367. Fla. Power \& Light Co. v. Lorion, 470 U.S. 729, 744 (1985); e.g., Routson v. Zinke, No. CV-15-8286, 2017 WL 4268907, at *3-4 (D. Ariz. Sept. 26, 2017) (remanding to the Bureau of Land Management for further consideration and denying petitioners' request to supplement or complete the record on review when the district court, which was apparently conversant in challenges to the Bureau of Land Management's denials of applications to correct land patents, could not determine material facts about the denial at issue sufficient to conduct APA review); Beach Commc'ns, Inc. v. FCC, 959 F.2d 975, 987-88 (D.C. Cir. 1992) (remanding, but stating that the court has discretion to choose between supplementation at the federal court and remand); Muwekma Ohlone Tribe v. Kempthorne, 452 F. Supp. 2d 105, 124 (D.D.C. 2006); Lands Council v. Powell, 395 F.3d 1019, 1029 n.10 (9th Cir. 2005) ("Normally, if an Agency's administrative record is incomplete, we would expect litigants to seek to supplement the record in the agency before seeking to expand the record before the district court." (emphasis added)); Portland Audubon Soc'y v. Endangered Species Comm., 984 F.2d 1534, 1549 (9th Cir. 1993) (stating that it has discretion to choose between supplementation and remand, and choosing remand so the agency and the petitioner could have a "vigorous and thorough" adversarial evidentiary hearing); In re Guardianship \& Conservatorship of Blunt, 358 F. Supp. 2d 882, 893 (D.N.D. 2005) (stating that supplementation should be chosen over remand only in "rare instances"); Ctr. for Native Ecosystems v. Salazar, 711 F. Supp. 2d 1267, 1276 (D. Colo. 2010); see also Motor Vehicle Mfrs. Ass'n v. State Farm, 463 U.S. 29, 57 (1983) (remanding for the agency to reformat where record appeared complete).

However, most courts that believe record deficiencies should be cured by supplementation prefer to do it in federal court, without calling it discovery. In other words, judicial actions like those this Article believes are inconsistent with the APA usually entail wanting the supplementation to happen in federal court. E.g., Pinnacle Armor, Inc. v. United States, 923 F. Supp. 2d 1226, 1245 (E.D. Cal. 2013). This may depend on how discrete the supplemented evidence is; if it is readily identified documents, then perhaps it makes sense to do it in federal court. See Water Supply \& Storage Co. v. U.S. Dep't of Agric., 910 F. Supp. 2d 1261, 1269 (D. Colo. 2012).

368. E.g., Fox Television Stations, Inc. v. FCC, 280 F.3d 1027, 1047 (D.C. Cir. 2002) (“Under the APA reviewing courts generally limit themselves to remanding for further consideration an agency order wanting an explanation adequate to sustain it."); Zzyym v. Kerry, 220 F. Supp. 3d 1106, 1114 (D. Colo. 2016) ("I find that the administrative record, as supplemented by the Fellows declaration, does not show that the decisionmaking process that resulted in the policy in question was rational. That is not to say that it can't be done, but the Department's first effort to get over the arbitrary and capricious hump was not convincing. The Court remands the matter to the Department for reconsideration.”); INS v. Orlando Ventura, 537 U.S. 13, 16 (2002) (“Generally speaking, a court of appeals should have remanded a case to an agency for a decision of a matter that statutes placed primarily in agency hands."). Contra United States v. Texas, 809 F.3d 134, 178 (5th Cir. 2015) (citing 5 U.S.C. $\$ 706(2)(2012)$ ) (stating that the proper remedy for failing to adhere to notice and 
dial purist" perspective. ${ }^{369}$

After remand, if the record truly was deficient, the agency could receive additional evidence. The agency could then write a stronger decision, if the problem was that the federal court could not find a rational connection between the facts found and the choice made-a "State Farm" problem. ${ }^{370}$ The agency could also act favorably toward petitioners, addressing grievances outside of the dispute resolution mechanisms of Articles I and III. Throughout, the petitioner should have to make a showing of prejudice, per 5 U.S.C. $\S 706$, which cautions courts that "due account shall be taken for the rule of prejudicial error" in APA review. ${ }^{371}$

Relatedly, courts should remand upon request from the agency. ${ }^{372}$ This saves judicial and agency resources where the agency knows that an administrative record is deficient or is concerned that a court, for whatever reason, will not agree that the administrative record is complete.

comment is to "set aside" and "enjoin" the agency action), aff" $d$ by an equally divided court, $136 \mathrm{~S}$. Ct. 2271 (2016). See Bagley, supra note 67, at 255 (examining "administrative law's systematic inattention to remedial questions").

369. Bagley, supra note 67, at 257-58 (quoting Henry J. Friendly, Chenery Revisited: Reflections on Reversal and Remand of Administrative Orders, 1969 DUKE L.J. 199, 223)). One scholar, responding to Professor Bagley's article, has argued that the remedial purist perspective's "current rule-based approach of the ordinary remand rule better accounts for [a] distrust" of the administrative state. Christopher J. Walker, Against Remedial Restraint in Administrative Law, 117 CoL. L. REV. ONLINE 106, 110 (2017).

370. See Motor Vehicle Mfrs. Ass' $n, 463$ U.S. at 43 (holding that courts must determine whether the agency has examined all relevant data and articulated a sufficient connection between the data and its decision).

371. 5 U.S.C. $\$ 706$ (2012); Shinseki v. Sanders, 556 U.S. 396, 409 (2009) (“[In an APA case,] the burden of showing that an error is harmful normally falls upon the party attacking the agency's determination."); NLRB v. Wyman-Gordon Co., 394 U.S. 759, 766 n.6 (1969) (emphasizing that Chenery "does not require that we convert judicial review of agency action into a ping-pong game," and that remand is not required where it "would be an idle and useless formality"); ATTORNEY GENERAL'S MANUAL, supra note 41, at 110 (stating that 5 U.S.C. $\$ 706$ merely "sums up in succinct fashion the 'harmless error' rule applied by the courts in the review of lower court decisions as well as of administrative bodies"). Some organic statutes have a stronger harmless-error rule. E.g., 42 U.S.C. § 9613(j)(4) (2012) (allowing the court to "disallow costs or damages only if the errors were so serious and related to matters of such central relevance to the action that the action would have been significantly changed had such errors not been made"). There is some perceived tension between Chenery and 5 U.S.C. $\S 706$ 's "prejudicial error" safety valve, but like the Supreme Court discussed in Mass. Trs. of E. Gas \& Fuel Assocs. v. United States, 377 U.S. 235, 248 (1964), Chenery should be applied when the error "bear[s] on the procedure used or the substance of decision reached." See also Bagley, supra note 67, at 302-07 ("Chenery in the trenches is not as absolute as Chenery in the casebooks.").

372. Calif. Cmtys. Against Toxics v. U.S. E.P.A., 688 F.3d 989, 992 (9th Cir. 2012) ("Generally, courts only refuse voluntarily requested remand when the agency's request is frivolous or made in bad faith.”); but see Lutheran Church-Mo. Synod v. FCC, 141 F.3d 344, 349 (D.C. Cir. 1998) (refusing to remand upon request because the request was found to be simply a tactic to avoid judicial review). 
Theoretically, if a petitioner remains dissatisfied, he or she could file a new APA action presuming that the six-year limitations period has not run. ${ }^{373}$

If the items to be completed are narrowly circumscribed and easy for the agency to submit in federal court, then a court might simply retain jurisdiction while the agency tries to fix whatever problem (merits or record) the court has identified. ${ }^{374}$ But, a court should generally send the case back down to the agency and not involve itself in the intricacies of how the record is completed. Ultimately, either option will not have much of an effect on incentivizing agencies to improve their behavior in the future. ${ }^{375}$

When remanding to agencies, courts possess and exercise the freedom to retain jurisdiction over a petition while the remand occurs. ${ }^{376}$ Admittedly, there does not appear to be a mechanism in the APA to remand without actually vacating or setting aside the decision; that is, a mechanism to remand to the agency while the federal court retains jurisdiction to re-review. Rather, it would suggest that the court must invalidate the agency action under 5 U.S.C. $\S 706$, enter judgment, and discharge its jurisdiction. ${ }^{377}$ Then, the petitioner would need to re-enter the

373. See 28 U.S.C. § 2401(a) (2012) (setting the APA statute of limitations).

374. Cf. Bagley, supra note 67 , at $299 \& 302$ (arguing that remedial purism does not make much sense when a federal court upon APA review remands to the agency to do an easy fix that may simply lead to a round trip back to the court).

375. Cf. Bagley, supra note 67, at 318 (arguing that by insisting on remand and vacatur or by refusing to take account of harmless error, courts are not making the agency better at applying the appropriate standards in the future. "In general, however, the courts should abandon the appealing but unlikely assumption that mechanically rebuking agencies for their errors will improve agency decisionmaking so much that the costs are worth bearing.").

376. E.g., Wood v. Burwell, 837 F.3d 969 (9th Cir. 2016) (noting the district court's decision to retain jurisdiction and citing district courts' equitable power to do so during an agency remand; also noting that in Social Security review actions, 42 U.S.C. $§ 405(\mathrm{~g})$ specifically prohibits courts from retaining jurisdiction during certain statutory prescribed remands); Baystate Med. Ctr. v. Leavitt, 587 F. Supp. 2d 37, 41 (D.D.C. 2008) (recognizing the court's "discretion to retain jurisdiction over a case pending completion of a remand and to order the filing of progress reports," but noting that "this discretion is typically reserved for cases alleging unreasonable delay of agency action or failure to comply with a statutory deadline, or for cases involving a history of agency noncompliance with court orders or resistance to fulfillment of legal duties"); Wyandotte Nation v. Salazar, 939 F. Supp. 2d 1137, 1153-54 (D. Kan. 2013) (retaining jurisdiction); Cobell v. Norton, 240 F.3d 1081, 1109 (D.C. Cir. 2001) (affirming a district court decision in the non-APA context that remanded to the agency but retained jurisdiction to ensure compliance. "While a court's retaining of jurisdiction of five years may be unusual, federal courts regularly retain jurisdiction until a federal agency has complied with its legal obligations, and have the authority to compel regular progress reports in the meantime."). If the parties stipulate to a remand under certain conditions, the court may retain jurisdiction by incorporating those conditions into its order of dismissal. See, e.g., Kokkonen v. Guardian Life Ins. Co. of Am., 511 U.S. 375, 381 (1994).

377. See 5 U.S.C. $§ 706(2)$ (2012) (directing a court to "hold unlawful and set aside agency action, findings, and conclusions" that fail the APA's standards of review). 
administrative process and re-exhaust remedies. Hewing to that conservative approach has the virtue of a bright-line rule.

However, several courts hold that it "is simply not the law" that a court must set aside an agency action that violates the APA with no room for judicial discretion in the matter. ${ }^{378}$ Many courts hold they have discretion to remand for further explanation without setting aside or ordering vacatur. ${ }^{379}$ Indeed, both Overton Park $^{380}$ and Lorion $^{381}$ pointedly remanded their cases upon determining that the record presented was not "the whole record." This is consistent with the power to remand a case found in pre-APA equitable judicial powers. ${ }^{382}$

In electing to remand the case, a court has no authority to order specific relief under the APA. ${ }^{383}$ Therefore, when a district court entertaining an APA challenge concludes that an administrative record is deficient, in addition to declining to add evidence in court via discovery, the

378. See, e.g., Sugar Cane Growers Coop. v. Veneman, 289 F.3d 89, 98 (D.C. Cir. 2002).

379. See, e.g., A.L. Pharma, Inc. v. Shalala, 62 F.3d 1484, 1492 (D.C. Cir. 1995) ("In deciding whether to vacate an agency's decision pending further explanation, we consider 'the seriousness of the order's deficiencies (and thus the extent of doubt whether the agency chose correctly) and the disruptive consequences of an interim change that may itself be changed." (citations omitted)); Wood, 837 F.3d at 976 ("[T] he factors courts weigh when deciding whether to remand to an agency without vacatur: (1) 'how serious the agency's errors are' and (2) 'the disruptive consequences of an interim change that may itself be changed." (quoting Cal. Cmtys. Against Toxics v. EPA., 688 F.3d 989, 992 (9th Cir. 2012))); Black Warrior Riverkeeper, Inc. v. U.S. Army Corps of Eng'rs, 781 F.3d 1271, 1289 (11th Cir. 2015) (declining to vacate because it could not conclude that the error was truly significant or that the conclusion was unlawful). However, there appears to be an intra-circuit split in the D.C. Circuit regarding the lawfulness of remand without vacatur. See In re Core Commc'ns, Inc., 531 F.3d 849, 862 (D.C. Cir. 2008) (Griffith, J., concurring); NRDC v. EPA, 489 F.3d 1250, 1262-64 (D.C. Cir. 2007) (Randolph, J., concurring); see also Checkosky v. SEC, 23 F.3d 452 (D.C. Cir. 1994) (opinion of Silberman, J. supporting the practice of remand without vacatur, and opinion of Randolph, J. arguing that remand without vacatur violates the APA), superseded on other grounds, Marrie v. SEC, 374 F.3d 1196 (D.C. Cir. 2004). However, the "prejudicial error" clause of 5 U.S.C. $\S 706$ provides a statutory grounding for remand without vacatur. Bagley, supra note 67 , at 257 .

380. Citizens to Pres. Overton Park, Inc. v. Volpe, 401 U.S. 402, 420 (1971) (holding that because the administrative record was not before the Court, "it is necessary to remand this case"), $a b$ rogated on other grounds by Califano v. Sanders, 430 U.S. 99 (1977).

381. Fla. Power \& Light Co. v. Lorion, 470 U.S. 729, 744 (1985) ("If the record before the agency does not support the agency action, if the agency has not considered all relevant factors, or if the reviewing court simply cannot evaluate the challenged agency action on the basis of the record before it, the proper course, except in rare circumstances, is to remand to the agency for additional investigation or explanation." (emphasis added)).

382. Duffy, supra note 87, at 129 n.76 (citing Am. Sch. of Magnetic Healing v. McAnnulty, 187 U.S. 94, 107-11 (1902); Ford Motor Co. v. NLRB, 305 U.S. 364, 373 (1939)).

383. Compare Cnty. of L.A. v. Shalala, 192 F.3d 1005, 1011 (D.C. Cir. 1999) ("[Under the APA, upon determining] that an agency made an error of law, the court's inquiry is at an end: the case must be remanded to the agency for further action consistent with the corrected legal standards. ... Not only was it unnecessary for the court [below] to retain jurisdiction to devise a specific remedy for the Secretary to follow, but it was error to do so." (citations omitted)), with Alvarado Cmty. Hosp. v. Shalala, 155 F.3d 1115, 1125 (9th Cir. 1998) (ordering specific relief). 
court should refuse to order the completion or supplementation of specific materials upon remand.

Moreover, remand without vacatur (as opposed to simple invalidation of the agency action) could be inefficient for the agency and petitioner to take their dispute out of federal court with the prospect of later returning, especially if the court is ordering the agency to enter just one or two pieces of evidence. ${ }^{384}$ Remand without vacatur discourages the proper, efficient interpretation of the APA. It also exposes the agency to liability for fees and expenses under the Equal Access to Justice Act ${ }^{385}$ when it otherwise would not be.

Courts should remand to produce the record. This gives the agency a chance to show that "the whole record" exists; the agency just failed to come up with it or compile it initially. The agency would also retain the freedom to render a new action based on the existing record, whether or not the record proffered was indeed "the whole record." (Note, however, that the decisionmaker would have to limit her review to the materials in the record proffered to federal court.) This is consistent with Supreme Court cases requiring lower courts to "uphold a decision of less than ideal clarity if the agency's path may reasonably be discerned." 386

\section{HOW THE APA RECORD RULE IS BEING INCORRECTLY INTERPRETED BY SOME COURTS AND LITIGANTS}

Enterprising petitioners have been able to accomplish two things in actions for APA review. First, they have been able to engage in discovery with the agency. Second, they have sometimes succeeded at adding materials to the administrative record - and thus the judicial record-for substantive consideration. In other words, many courts are not taking the administrative record as presented, and they are doing so well beyond the limited exceptions identified above.

\footnotetext{
384. See A.L. Pharma, Inc., 62 F.3d 1484, 1492 (D.C. Cir. 1995).

385. 28 U.S.C. $\S 2412(d)(1)(A)$ (2012) (applying this explicitly to "proceedings for judicial review of agency action").

386. FCC v. Fox Television Stations, Inc., 556 U.S. 502, 513-14 (2009) (discussing APA governing principles) (quoting Bowman Transp., Inc. v. Ark.-Best Freight Sys., Inc., 419 U.S. 281, 286 (1974)).
} 


\section{A. Why Some APA Petitioners and Courts Are Not Following the Record Rule}

Before discussing where litigants and courts go astray, it is revealing to understand the reasons litigants and courts have for avoidingconsciously or unconsciously-the proper scope of the APA record rule we have delineated. Petitioners are incentivized to advocate for expanding the administrative record beyond its appropriate scope for a number of reasons. Principally this may be done to increase the odds of winning; adding non-record or unredacted record materials before the federal court gives them a second bite at the apple. ${ }^{387}$ A petitioner is before a federal court because he or she has lost before the agency. If a petitioner challenges the record presented by the agency to the court, arguing the administrative record should include more materials, then the petitioner presumably expects the materials to be beneficial to his case. In 5 U.S.C. $\S 706(2)(A)$ arbitrary and capricious review, the petitioner could highlight allegedly relevant factors that the agency did not consider, reveal internal inconsistencies that are unexplained, reveal generally normative behavior that could be misconstrued as bad faith or improper behavior, induce an agency to settle an action by shifting the agency's risk tolerance, gain access to data that is not otherwise available under the Freedom of Information Act, and exploit human error in the privilege review or Freedom of Information Act release contexts. Petitioners may plausibly also want to erode deferential arbitrary and capricious standard in favor of de novo review, ${ }^{388}$ even though Congress considered and rejected that option before the APA's passage. ${ }^{389}$

Discovery may also serve the goals of petitioners, especially organizational petitioners, to discover fodder for future lawsuits. This may aid such petitioners whether in a larger class action or a small case under, say, the Federal Tort Claims Act or for a constitutional violation under

387. In receiving a second opportunity for favorable agency action, an APA petitioner's odds do not necessarily increase. See Robert L. Glicksman \& Emily Hammond, Agency Behavior and Discretion on Remand, 32 J. LAND USE \& ENVTL. L. 483, 484-87 (2017) (noting how an agency may simply rule against the petitioner again on remand and identifying "four variables that may hold predictive value as to agencies' exercise of discretion following judicial remand: the nature of the remedy; the timeline; the valence of the decision; and the presidential administration").

388. Lands Council v. Powell, 395 F.3d 1019, 1030 (9th Cir. 2005) ("Were the federal courts routinely or liberally to admit new evidence when reviewing agency decisions, it would be obvious that the federal courts would be proceeding, in effect, de novo rather than with the proper deference to agency processes, expertise, and decision-making.").

389. See supra note 104; see also Wong Yang Sung v. McGrath, 339 U.S. 33, $36-37$ (1950), superseded by statute as stated by 502 U.S. 129 (1991). Of course, we are not referring to 5 U.S.C. $\S 706(2)(F)$ de novo review. See supra note 183. 
Bivens. $^{390}$ Impermissible record expansion through an APA lawsuit serves as a sort of unique discovery to tee up such cases.

A more cynical view holds that forcing the unwarranted disclosure of documents helps aggrieved individuals harass the agency. This can be done to slow down the agency's work and effectively enjoin agency functions for policy or political goals, with the possibility of securing attorneys' fees $^{391}$ in the process. Pressing the agency for discovery, with the added benefit of loudly clamoring when discovery is not immediately available or when discovery yields tantalizing materials, can also generate favorable press for issue advocates. Advocacy groups can then parlay that press into fundraising. Ironically, one reason President Truman vetoed the Walter-Logan Bill, a law that would have provided less deferential judicial review, was because he thought it was the work of lawyers "who desire to have all processes of government conducted through lawsuits." 392 Even when untoward motives are not certain, these types of records disputes have infected several lawsuits that are high profile because of their merits, thus risking the conflation between records issues and merits issues. ${ }^{393}$

Petitioners accomplish these goals in a number of ways. As the foregoing indicates, while the APA's "whole record" requirement does have a readily discernible meaning, there is considerable confusion over the scope of APA record review. The bench and bar alike confuse both the administrative "record" and the judicial "record" created and referenced in litigation, and the completion/supplementation distinction. ${ }^{394}$

\footnotetext{
390. Bivens v. Six Unknown Named Agents, 403 U.S. 388 (1971).

391. See 28 U.S.C. $§ 2412$ (2012).

392. Croley, supra note 105.

393. See, e.g., In re United States, 138 S. Ct. 443 (2017) (challenge to DACA); Motion in Limine to Limit Evidence at PI Hearing, Pennsylvania v. Trump, Civil Action No. 17-4540, ECF No. 48 (E.D. Pa. Dec. 11, 2017) (in a challenge to the Affordable Care Act regulations exempting religious organizations from providing contraceptive services, moving to prohibit supplementation of the administrative record; the motion was summarily denied); Further Supplemental Joint Case Management Statement, Gill v. Dep't of Justice, No. 3:14-cv-3120, ECF No. 71 (N.D. Cal. Sept. 4, 2015) (challenge to the Department of Justice's Suspicious Active Reporting program, alleged to be a vast domestic intelligence network); Defendants' Motion for a Protective Order, Premier Med. Supplies, Inc. v. Leavitt, Case No. 1:07-CV-3809, ECF No. 18, (N.D. Ohio Apr. 21, 2008) (challenge to Medicare regulations); Empresa Cubana Exportadora de Alimentos y Productos Varios v. U.S. Dep't of Treasury, 606 F. Supp. 2d 59, 68-69 (D.D.C. 2009) (in a challenge to an aspect of the embargo on Cuban entities registering or renewing U.S. trademarks, defending the government's inclusion of a declaration as background information that was not impermissible extra-record evidence); Brief for Respondents in Opposition, Holy Land Found. v. Ashcroft, No. 03-775 (U.S. 2003) (in a challenge to Specially Designated Global Terrorist designation which blocked monetary transactions involving the plaintiff's property, noting a prior supplementation dispute).

394. Young, supra note 121; Nat'l Mining Ass'n v. Jackson, 856 F. Supp. 2d 150, 159 (D.D.C. 2012) (declining to supplement the record with four documents, but agreeing to view them apart
} 
To a large extent, that is understandable. Judges and advocates are often most familiar with the default rules of traditional civil discovery, which the APA transcends in several key aspects. A court may also order the parties to meet and confer regarding whether the administrative record should be supplemented, thrusting the issue into solely the parties' domain. ${ }^{395}$ Judges may have a general judicial distrust of agencies. ${ }^{396}$ Some argue that judges and the parties possibly may believe that having too much discovery is a harmless error, or be otherwise ignorant of the significance of this issue. ${ }^{397}$

Confusion in this sphere is not solely attributable to judges' possible prejudices or inability to grapple with a slight variation on the law. The APA does not define "the whole record" or say when "the whole record" can or cannot be completed or supplemented. Nor was Overton Park meant to bear the weight that judges and parties seeking APA guidance place on it, especially regarding remedies. Its dicta can be vexing and misleading. ${ }^{398}$ For instance, Overton Park endorsed discoveryincluding depositions of high-ranking officials - as a possible remedy, which is inappropriate for the reasons discussed earlier. ${ }^{399}$ To its credit, the Supreme Court moved away from that in Camp v. Pitts, saying an agency could not only offer affidavits and testimony, but give "such additional explanation of the reasons for the agency decision as may prove necessary." 400 Camp emphasized that this did not need to occur in the

from the APA record as "extra-record evidence," without explaining the significance of that distinction); WildEarth Guardians v. Salazar, 670 F. Supp. 2d 1, 5 n.4 (D.D.C. 2009) (conflating completion and supplementation and calling both "supplementation"); La Union del Pueblo Entero v. Fed. Emergency Mgmt. Agency, 141 F. Supp. 3d 681, 694 (S.D. Tex. 2015) (calling completion "supplementation" and supplementation "extra-record evidence").

395. E.g., Amgen Inc. v. Hargan, 285 F. Supp. 3d 397, 402-403 (D.D.C. 2017).

396. See Bagley, supra note 67, at 315 ("Judges of whatever political stripe are acculturated into a legal community that views the administrative state as a leviathan that can be tamed only through zealous judicial oversight. There's no substantial constituency clamoring about the serious costs of that attitude.").

397. See Robert A. Anthony, The Supreme Court and the APA: Sometimes They Just Don't Get It, 10 ADMIN. L.J. AM. U. 1, 2 (1996) ("[S]ome of the time, the Justices just don't get it. After 50 years of the APA, many things should be clearer than they are.").

398. See id. at 3 (taking aim at Overton Park, but on different grounds than those challenged here, "Beyond neglect, the Court befogs APA concepts by sloppy and bloated opinions, which leave confusion in their wake. The Court's most hurtful sin is its pervasive imprecision. Too often, even sound holdings are accompanied by gratuitous and ill-considered dicta that are susceptible to damaging misapplication." (citation omitted)); see also, e.g., In re United States, 138 S. Ct. 371, 373-74 (Breyer, J., dissenting from grant of stay) (arguing that when Overton Park stated that it would accept the record presented by the agency, it really meant the record presented by the agency proceedings, thus the court, not the agency, was the ultimate arbiter of the record's contents), remanded, 138 S. Ct. 443.

399. See infra Section III.F.

400. Camp v. Pitts, 411 U.S. 138, 143 (1973). 
federal litigation - it should occur on remand. ${ }^{401}$ Lorion reinforced that remand to the agency is "the proper course, except in rare circumstances." 402 But these cases never explicitly repudiated Overton Park's language on this point. So whatever unintended gaps or secondary consequences Overton Park may have created with its general terms, the Supreme Court has not taken up the issue anew to address them, even when it had "whole record" issues before it in fall 2017. ${ }^{403}$

The record rule progenitor, Overton Park, also has narrow utility because it dealt with a very specific scenario: the complete absence of a record, which could not be saved by the Secretary's post hoc justifications, which ran afoul of Chenery I. As Camp showed, if the agency presents the bare minimum necessary to qualify as a "record"-any explanation, even a "curt" one, that demonstrates some reason for the final action taken - then there is no ground to supplement the record. ${ }^{404}$ Rather, the question becomes legal: on that record, was the agency's action arbitrary and capricious, and so forth. ${ }^{405}$ Insofar as there are issues with the curt explanation, a substantive inquiry must be conducted that asks whether there is a rational connection between the facts found and the conclusions reached. The substantive inquiry also must ask whether the dispute should be resolved not by augmenting the record but by conducting a State Farm merits inquiry. ${ }^{406}$ Even then, Overton Park did not permit the record to be supplemented. ${ }^{407}$ It simply remanded to the lower courts to oversee the completion of the record. ${ }^{408}$ Further, Overton Park established, without full discussion or elaboration, a "bad faith" exception where petitioners can obtain discovery even where a record is made and presented. $^{409}$

Moreover, the record rule is not faithfully followed in the federal district courts because of the theoretical difficulties meshing record review with 5 U.S.C. $\S 706(1)$ cases in which an agency unlawfully withheld or unreasonably delayed action. In such cases, "there is no final agency action to demarcate the limits of the record." 410 But 5 U.S.C. $\S 706(1)$ cas-

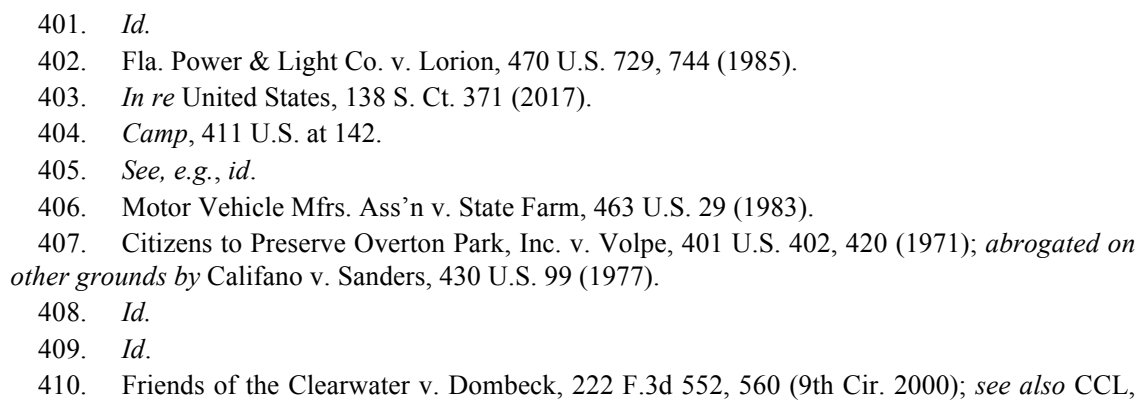


es are the equivalent of mandamus claims, which present purely legal issues and do not need an administrative record to review the agency's unlawfully withheld or unreasonably delayed action. ${ }^{411}$ As the Supreme Court's 2017 and 2018 decisions In re United States and In re Department of Commerce show a writ of mandamus is still a viable avenue for relief. $^{412}$

Finally, APA petitioners are able to circumvent the record rule for practical considerations. The record may look different in every case, making it tough for the bench and bar to ascertain what a record in a given APA case "should" look like. This is especially relevant with judges who do not often adjudicate APA records disputes and who do not realize that administrative records are generally consistent in different classes of adjudications. Further, the petitioners' equities may be compelling. Petitioners may complain that only the government has access to all the documents, so they should be able to find out whether the agency considered something that is not in the presented record. This was a factor in the DACA litigation, where the district judge insisted on proceeding to discovery notwithstanding the unresolved jurisdictional threshold defenses because of the impending end to the DACA program, which the judge pointed out would adversely affect thousands of immigrants. ${ }^{413}$ These attractive qualities often overpower the legal reasons for narrowly defining and handling "the whole record" in APA judicial review.

\section{B. How Some APA Petitioners and Courts Are Not Following the Record Rule}

APA petitioners succeed in a number of ways in going beyond what the record rule should permit. The sieve is not in a single place; petitioners may take advantage of any of the myriad circuit splits and hazy standards described above. APA petitioners may also argue that discov-

\footnotetext{
Inc. v. United States, 39 Fed. Cl. 780, 791 (1997) ("[When] the government is being sued for inaction... [t]here is less reason to presume that the record assembled by the agency is presumptively complete.").

411. See Norton v. S. Utah Wilderness Alliance, 542 U.S. 55, 63 (2004) (“APA carried forward the traditional practice... when judicial review was achieved through... mandamus"); S.F. Baykeeper v. Whitman, 297 F.3d 877, 886 (9th Cir. 2002) ("EPA does not presently have a statutory duty to act. Therefore, there can be no unreasonable delay ...."); Mt. Emmons Mining Co. v. Babbitt, 117 F.3d 1167, 1170 (10th Cir. 1997). But see Independence Mining Co. v. Babbitt, 105 F.3d 502, 511, 507 n.7 (9th Cir. 1997) (in a 5 U.S.C. § 706(1) case, the Solicitor of Labor submitted a declaration to defeat a TRAC factors argument).

412. In re Dep't of Commerce, No. 18A375, 2018 WL 5259090 (U.S. Oct. 22, 2018); In re United States, 138 S. Ct. 443 (2017).

413. In re United States, $138 \mathrm{~S}$. Ct. at 445.
} 
ery must be completed or supplemented; which again, courts are not consistent on terminology and often conflate the two. They may make constitutional or "non-APA" claims challenging agency action, claiming exemption from the record rule. ${ }^{414}$ This may be especially likely if petitioners can take advantage of the mushy standard used in some circuits: all materials considered "indirectly" by the agency. ${ }^{415}$ Petitioners may encourage courts to use discovery to conduct any completion or supplementation, instead of remanding to the agency (regardless of vacatur or retention of jurisdiction). ${ }^{416}$ Of course, if an agency finds itself in discovery, discovery must be "proportional to the needs of the case" per the usual discovery rules. ${ }^{417}$

Courts often entertain the petitioners' arguments because the courts see themselves as the ultimate arbiter of whether the administrative record is complete. ${ }^{418}$ That is a fair view, so long as they credit the presumption of agency regularity in compiling the administrative record. But because courts fear that an agency can omit unfavorable documents from the record, they sometimes want to look beyond the record presented to ensure that they have the whole record. ${ }^{419}$ This may be an even greater issue in 5 U.S.C. $§ 706(1)$ delay cases, where the record falls within less conventional bounds. By subjecting an agency to record completion or supplementation, a court may also - whether intentionally or not-affect the agency's decision to settle.

\footnotetext{
414. See supra note 274 .

415. See supra note 216

416. E.g., Little Co. of Mary Hosp. v. Sebelius, 587 F.3d 849, 856 (7th Cir. 2009).

417. FED. R. CIV. P. 26(b)(1).

418. Tenneco Oil Co. v. Dep’t of Energy, 475 F. Supp. 299, 317 (D. Del. 1979) (“DOE may not unilaterally determine what shall constitute the administrative record and thereby limit the scope of this Court's inquiry."); Bar MK Ranches v. Yuetter, 994 F.2d 735, 740 (10th Cir. 1993); Am. Farm Bureau Fed'n v. EPA, Civil No. 1:11-CV-67, 2011 WL 6826539, at*3 (M.D. Pa. Dec. 28, 2011) (" $[\mathrm{N}]$ otwithstanding this presumption in favor of EPA, EPA does not have complete control over the contents of the administrative record.").

419. Am. Farm Bureau Fed'n, 2011 WL 6826539, at *3 (using this reasoning to go on a hunt, intact presumption of regularity notwithstanding, for irregularities in the administrative record presented); but see supra note 240 and the cases cited therein. Some scholarship alleges that agencies affirmatively omit unfavorable documents from the administrative record in federal court. Saul, supra note 203, at 1326 ("Increasingly, federal agencies are misusing the deliberative process privilege by failing to properly assert and justify the privilege.... [Litigants] must frequently resort to Motions to Compel Completion of the Administrative Record when it becomes apparent that the defendant agency has withheld documents from the record." (citations omitted)); Rohlf, supra note 78, at 576, 576 n.10 (2009) ("Particularly during the tenure of George W. Bush, the federal Executive Branch placed a high premium on secrecy in many of its dealings, a philosophy that manifested itself in part as a trend toward increasingly skimpier records filed with reviewing courts pursuant to the Administrative Procedure Act ('APA') when decisions made by federal agencies were challenged." (internal footnote omitted)).
} 
When a court rules against an agency in an APA case, the remedies have varied. Some courts have proceeded to manage discovery, like compelling the testimony of agency officials, either in post-decision written statements or through live testimony at a hearing. ${ }^{420}$ This has posthoc, Chenery I issues, although courts have tried to distinguish Chenery $I^{421}$ Other courts set aside the rule because of the deficient record and proceed no further. ${ }^{422}$ These methods are at odds with the ideal remedies available when agency action presents a record or merits issue. ${ }^{423}$

\section{Negative Consequences of Misapplying the Record Rule}

Misapplying the APA record rule in judicial review carries several secondary consequences that may not be apparent in any individual case. Primarily, imposing superfluous burdens on the agencies wastes resources and shifts expenditure away from core agency functions. ${ }^{424}$ This waste of tax dollars is compounded by the occasional need to contract outside technical services to engage in the surplus discovery.

Completion and supplementation also waste time. The process of challenging and defending agency action already takes a long time, as it spans the agency decision-making itself, administrative appeals of that action, federal district court review, and then "duplication of the identical task ... in the court of appeals." 425 Even when the record contents are

420. See Citizens to Preserve Overton Park, Inc. v. Volpe, 401 U.S. 402, 420 (1971), abrogated on other grounds by Califano v. Sanders, 430 U.S. 99 (1977); Impresa Construzioni Geom. Domenico Garufi v. United States, 238 F.3d 1324, 1339 (Fed. Cir. 2001) (ordering the deposition of a contracting officer in lieu of remand because the decision being challenged was so personal to the officer); Consumer Fed'n of Am. v. Dep't of Health \& Human Servs., 83 F.3d 1497, 1507 (D.C. Cir. 1996) (" $[T]$ his court has on occasion flexed the record requirement to allow the admission of agency declarations that merely illuminate reasons obscured but implicit in the administrative record." (citations omitted)). The Consumer Federation court did not identify its authority to "flex" the APA's and Overton Park's requirements, but its decision ultimately did reject an agency official's litigation affidavit as falling on the "post hoc" side of the line. Consumer Fed'n of Am., 83 F.3d at 1507.

421. Nat'1 Elec. Mfrs. Ass'n v. U.S. Dep't of Energy, 654 F.3d 496, 514-15 (4th Cir. 2011) ("[The agency's] responsibility includes providing reasons for its actions sufficient to permit assessment by a reviewing court. Most assuredly, however, this responsibility does not oblige the agency to provide exhaustive, contemporaneous legal arguments to preemptively defend its action." (citations omitted)); Independence Mining Co. v. Babbitt, 105 F.3d 502, 511-12 (9th Cir. 1997) (excusing a post hoc rationalization in a $\S 706(1)$ action because the agency never had the opportunity to make a statement of its policy and justifications).

422. BECK, supra note 35, at 78-79; Allied-Signal, Inc. v. U.S. Nuclear Regulatory Comm'n, 988 F.2d 146, 150-51 (D.C. Cir. 1993) ("The decision whether to vacate depends on the seriousness of the order's deficiencies (and thus the extent of doubt whether the agency chose correctly) and the disruptive consequences of an interim change that may itself be changed." (citations omitted)).

423. See supra Section III.E.

424. See, e.g., Bagley, supra note 67, at 318; Davis, supra note 190.

425. Fla. Power \& Light Co. v. Lorion, 470 U.S. 729, 744 (1985). 
not challenged, the agency must ascertain the circuit's standards for "the whole record," search for responsive documents in accordance with those standards, exclude deliberative process materials (if the circuit permits such), redact for privilege, and create a log. The need to brief issues surrounding the record prolongs the dispute between the parties, and the agency may need to repeat part of this process if the court orders the agency to supplement the record with new materials.

The toll on agencies is apparent from Overton Park itself. On remand from the Supreme Court, the district court held a twenty-five-day trial with 240 exhibits. ${ }^{426}$ In a recent case, the district court ordered the agency to produce deliberative process materials. ${ }^{427}$ The agency had to apply thirty-one broad search terms to the records of seventeen different email custodians over a twenty-three-year period, which required review of over 400,000 pages, which would take over a year under current staffing levels. ${ }^{428}$ In the DACA mandamus case, even though the government succeeded in securing a stay on record completion and supplementation pending a ruling on threshold jurisdictional defenses, the agencies and Department of Justice counsel had to spend time brief-writing because the case was appealed first to the Ninth Circuit and then to the Supreme Court, where the agencies filed multiple briefs. ${ }^{429}$ This was not necessarily a function of over-lawyering the case. In remanding the case, the Supreme Court explicitly stated that if the jurisdictional arguments are denied, the lower courts should consider whether the agencies meet the standards for interlocutory appeal. ${ }^{430}$

Improper construction of the record rule also exacts costs at the individual level. Employees of the agencies must divert their attention to these unpredictable and unexpected record issues. Agency officials' time is expended in depositions. In the DACA litigation, where 30,000 documents were ordered to be produced in a matter of days, a government attorney reported at oral argument that "[o]ne out of every 14 [Immigration and Customs Enforcement] lawyers is devoted to considering the discovery requests in this case. Every [Department of Homeland Security] litigation lawyer at [Department of Homeland Security] headquarters is considering the discovery requests in this case. Programmatic interests are being subordinated to follow the discovery requests in this case." ${ }^{431}$

\footnotetext{
426. Citizens to Pres. Overton Park, Inc. v. Volpe, 335 F. Supp. 873, 878 (W.D. Tenn. 1972).

427. In re Price, No. 17-71121 (9th Cir. filed Apr. 19, 2017).

428. Id. at 9 .

429. See In re United States, 138 S. Ct. 443 (2017).

430. Id. at 445 .

431. Josh Gerstein, Appeals Courts Block Access to DACA Cancellation Files, POLITICO (Oct.
} 
If the agency is subject to a preliminary injunction, temporary restraining order, or an APA stay, ${ }^{432}$ then it is prevented from executing its mission for that much longer. The longer the APA review process extends (it took over a decade for the Overton Park dispute to reach the Supreme Court, which did not even finally resolve the dispute ${ }^{433}$ ), the more likely it is to extend past the tenure of a single agency head. ${ }^{434}$ This can stymy agency action if a new head comes in and wants simply to reverse course. $^{435}$

Second, the current record rule landscape can harm petitioners as well. Although instances are not readily found in case law, an agency, if ordered to supplement, might take advantage of the process and slip in post hoc rationalizations. After all, agencies have enormous investments in their decisions. ${ }^{436}$ As one scholar put it,

An agency also may work for months or even years on the process of reaching a decision-engaging the public, preparing detailed and lengthy environmental and other analyses, and consulting with other agencies, tribes, and governmental bodies. In this light, a great deal is often riding on the contents of an agency's administrative record. ${ }^{43}$

Third, as the inconsistent district and circuit court decisions addressing the scope of the APA record indicate, the current practice fosters judicial indeterminacy. In turn, before litigation an agency may decide to

24, 2017, 10:45 PM), https://www.politico.com/story/2017/10/24/dreamers-daca-appeals-courtsaccess-244138 [https://perma.cc/78RD-H8BK] (quoting Deputy Assistant Attorney General Hashim Mooppan). See, e.g., Batalla Vidal v. Duke, 295 F. Supp. 3d 127 (E.D.N.Y. 2017); In re United States, 138 S. Ct. 443.

432. See 5 U.S.C. $§ 705$ (2012).

433. Citizens to Pres. Overton Park, Inc. v. Volpe, 401 U.S. 402, 421-22 (1971) (Blackmun, J., concurring), abrogated on other grounds by Califano v. Sanders, 430 U.S. 99 (1977).

434. See, e.g., id. at 422-23 (1971) (Blackmun, J., concurring) ("The administrative decisions under attack here are not those of a single Secretary; some were made by the present Secretary's predecessor and, before him, by the Department of Commerce's Bureau of Public Roads.").

435. Cf. Lawrence Hurley, Trump's Transgender Move Puts Spotlight on Supreme Court Case, REUTERS (Feb. 23, 2017, 3:17 PM), http://www.reuters.com/article/us-usa-trump-lgbt-court/trumpstransgender-move-puts-spotlight-on-supreme-court-case-idUSKBN1622LH [https://perma.cc/2T95HMFT] (describing how Trump's Department of Education reversed Obama's Department of Education's decision on whether Title IX covers transgender students, which then led to the Trump Administration (successfully) asking the Supreme Court to dismiss certiorari granted for a case on this issue); see Gloucester Cty. Sch. Bd. v. G.G. ex rel. Grimm, 137 S. Ct. 1239 (Mem) (2017) (vacating the Fourth Circuit's decision in the transgender student's favor "in light of the guidance document issued by the Department of Education and Department of Justice on February 22, 2017.”).

436. See Walter O. Boswell Mem'l Hosp. v. Heckler, 749 F.2d 788, 792 (D.C. Cir. 1984) (“To review more than the information before the Secretary at the time she made her decision risks our requiring administrators to be prescient or allowing them to take advantage of post hoc rationalizations ...").

437. Rohlf, supra note 78, at 603-04. 
overcorrect in its compilation of the record to avoid later supplementation or discovery. This concern could drive the unsettled interagency guidance on record creation and preservation, as agencies are unsure which courts will permit petitioners to add to the administrative record in federal court. Many commentators discount the virtues of presuming agency regularity. ${ }^{438}$ But the "ambiguity, confusion, and even contradiction [over what needs to end up in the record] increases the overall likelihood that agencies will produce less than a 'full' record supporting their decisions. $" 439$

Because different standards apply in different circuits, it is hard for an agency to predict what a court will do with the administrative record that it furnishes. Because they are part of the federal government and perform actions that may have dispersed effects, agencies may be subject to personal jurisdiction in several different district courts. Under the fractured, circuit-dependent law, the sufficiency of the record comes down to where the petitioner files a suit. The costs imposed on the agency could vary depending on the judge assigned to the case.

Even if a court denies a motion to supplement the record, the agency can be disadvantaged because the mere filing of a motion to supplement the record can force the court to examine verboten material. The Tenth Circuit, despite employing several record rule exceptions itself, observed: "[W]hen such justifications are offered the court is forced as a practical matter to examine the material, whether or not motions to supplement the record are granted." 440 This, in turn, may increase the probability that the agency settles. Judicial willingness to improperly complete or supplement the record can change the risk calculus of representative counsel because such judicial orders imply a propensity to rule against the government on the merits.

This judicial indeterminacy may unnecessarily expend the judiciary's time and resources as well. If " $t]$ he court's inquiry outside the record is limited to determining whether the agency has considered all relevant factors or has explained its course of conduct or grounds of decision," the question raised is whether the evidence sought goes to the merits or to the "consideration of all relevant factors" inquiry. This can be difficult to correct, as courts of appeals typically review district courts' de-

\footnotetext{
438. See Saul, supra note 203, at 1312-13 (arguing that the presumption should be rebutted with a "minimal" showing of irregularity, given the importance of delivering the reviewing court a full record).

439. Rohlf, supra note 78, at 607.

440. Am. Mining Cong. v. Thomas, 772 F.2d 617, 626 (10th Cir. 1985).

441. Animal Def. Council v. Hodel, 840 F.2d 1432, 1436 (9th Cir. 1988).
} 
terminations of whether to allow in extra-record evidence for abuse of discretion. ${ }^{42}$ In the In re United States DACA case, the per curiam Supreme Court disclaimed an interest in engaging with the underlying discovery dispute, remanding for the district court to examine the agency's jurisdictional defenses first. ${ }^{443}$ While a majority of the Court stayed the discovery order, four dissenting Justices explicitly complained that the Court was "poorly positioned to second-guess district courts' determinations in this area." APA "whole record" may evade correction. A court might engage in a simple order to supplement or complete the record, knowing that its margin for error is accordingly wide even beyond the deferential "abuse of discretion" standard of appellate review.

Fourth, permitting consideration of extra evidence might contribute to the erosion of the arbitrary and capricious standard, replacing it with some less deferential standard. ${ }^{445}$ It may not approach the neat category of de novo review, although some scholars have questioned the consistency with which courts apply these standards of review. ${ }^{446}$

Fifth, the current state of 5 U.S.C. $\S 706$ interpretation raises constitutional separation of powers concerns. ${ }^{447}$ The practice unwarrantedly intrudes on the legislative branch, as recognized in the Vermont Yankee principle that the judiciary may not impose requirements on the executive that the legislature has not. ${ }^{448}$ This could be especially intrusive

442. See, e.g., Theodore Roosevelt Conservation P'ship v. Salazar, 616 F.3d 497, 507 (D.C. Cir. 2010); Axiom Res. Mgmt., Inc. v. United States, 564 F.3d 1374, 1378 (Fed. Cir. 2009); Little Co. of Mary Hosp. v. Sebelius, 587 F.3d 849, 856 (7th Cir. 2009); Citizens for Alts. to Radioactive Dumping v. U.S. Dep't of Energy, 485 F.3d 1091, 1096 (10th Cir. 2007); Sierra Club v. Slater, 120 F.3d 623, 632-39 (6th Cir. 1997); Voyageurs Nat'l Park Ass'n v. Norton, 381 F.3d 759, 766 (8th Cir. 2004) (giving deference "absent a gross abuse of discretion").

443. See In re United States, 138 S. Ct. 443, 445 (2017), rev'd, 138 S. Ct. 443.

444. In re United States, 138 S. Ct. 371, 375 (Breyer, J., dissenting from grant of stay).

445. Axiom Res. Mgmt., Inc., 564 F.3d at 1380 ("The purpose of limiting review to the record actually before the agency is to guard against courts using new evidence to "convert the "arbitrary and capricious" standard into effectively de novo review."); see Aram A. Gavoor \& Daniel Miktus, Oversight of Oversight: A Proposal for More Effective FOIA Reform, 66 CATH. U. L. REv. 525, 538-39 (2017) (discussing how courts review agency action under the Freedom of Information Act, part of the APA, more deferentially than the de novo standard that is intended).

446. See Paul R. Verkuil, An Outcomes Analysis of Scope of Review Standards, 44 WM. \& MARY L. REV. 679 (2002).

447. Amfac Resorts, L.L.C. v. Dep’t of Interior, 143 F. Supp. 2d 7, 11 (D.D.C. 2001) (“Were courts cavalierly to supplement the record, they would be tempted to second-guess agency decisions in the belief that they were better informed than the administrators empowered by Congress and appointed by the President." (internal quotations omitted) (quoting San Luis Obispo Mothers for Peace v. Nuclear Regulatory Comm'n, 751 F.2d 1287, 1325-26 (D.C. Cir. 1984), overruled on other grounds, 789 F.2d 26 (D.C. Cir. 1986) (en banc))).

448. Vt. Yankee Nuclear Power Corp. v. Nat. Res. Def. Council, Inc., 435 U.S. 519 (1978). 
where courts order the production of an administrative record early in the action, before the government has had a chance to brief initial jurisdictional issues, and before the court has decided a motion to dismiss on jurisdictional grounds. A particularly striking example of this overreach arises when a judge ordered an acting cabinet member to sit for a fourhour deposition, even before the cabinet member's agency could file a motion to dismiss. ${ }^{449}$ The Supreme Court, which overturned that order, ${ }^{450}$ has shown interest in maintaining separation of powers in the realm of administrative law. For example, in recent years, some Justices have begun calling for the elimination of so-called "Seminole Rock" or "Auer" deference on separation of powers grounds. ${ }^{451}$ Some Members of Congress have recently proposed legislation that would shift case law deference framework on questions of law away from federal agencies. ${ }^{452}$

Of course, the judiciary has an important role to play in APA review. ${ }^{453}$ Many aspects of APA review do require legal determinations from the court, including the ultimate standard of review and determination as to whether the record presented by the agency to the court is "the whole record." But, the judiciary can review agency action just as efficiently with a more predictably assembled record that is subject to fewer challenges. If it is simply that the judiciary wants to review agency action more penetratingly, then that is for Congress to decide.

Sixth, improperly interpreting the record rule is wrong because it flouts the rule of law. The record rule springs from 5 U.S.C. $\S 706$, which largely addresses matters of review within the judiciary's domain. The APA, this administrative bill of rights, may be nonspecific, ${ }^{454}$ but as

449. Regents of the Univ. of Cal. v. U.S. Dep't of Homeland Sec., Case Nos. C 17-5211, C 175235, C 17-5329, C 17-5380, ECF No. 46 (N.D. Cal. Oct. 24, 2017) (ordering the Acting Secretary of Homeland Security to sit for a four-hour deposition in DACA litigation, worried about the program's looming end).

450. See In re United States, 138 S. Ct. 443 (2017).

451. Perez v. Mortg. Bankers Ass'n, 135 S. Ct. 1199, 1217-25 (2015) (Thomas, J., concurring in the judgment); see Bowles v. Seminole Rock \& Sand Co., 325 U.S. 410 (1945); Auer v. Robbins, 519 U.S. 452 (1997).

452. See, e.g., H.R. 5, tit. 2, 115th Cong. ("Separation of Powers Restoration Act"); H.R. 4768, 114th Cong. See also Memorandum from Admin. Conf. of the United States (ACUS) Interns to ACUS Research Chief Reeve T. Bull (Jan. 30, 2017) https://www.acus.gov/sites/default/files /documents/Regulatory\%20Reform\%20Legislation\%20Memo\%202-13-2017.pdf [https://perma.cc /N3AJ-ARD5] (compiling APA reform bills introduced from 2011 to early 2017). See also, e.g., Elizabeth V. Foote, Statutory Interpretation or Public Administration: How Chevron Misconceives the Function of Agencies and Why It Matters, 59 ADMIN. L. REV. 673, 674 (2007) (arguing that Chevron was wrongly decided).

453. Rohlf, supra note 78, at 586 ("[I]n what amounts to an unheralded reprise of Marbury v. Madison in the context of the APA, courts have made it clear that the judiciary has the last word in deciding when agencies' records are sufficient." (citation omitted)).

454. As discussed previously, the specificity of required record inputs depends on the type of 
discussed above, there are several good, relatively clear reasons why the APA record rule means what we think it does, and there is little justification for the courts deviating from that interpretation. Courts' unwillingness to hew to the law or their ignorance to take the straightforward step in properly interpreting the record rule is further compounded by the fact that not all courts are doing this. This makes the scofflaws stand out even further and gives them opportunities to reassess that not many courts have taken.

The problems presented by the judiciary's and litigants' approach to APA administrative records may be worsening, given the hyperpartisanship and the growing resources of advocacy groups that now may emerge to be the heyday of strategic issue advocacy. For those who vehemently disagree with the underlying policy of an executive agency, even lawfully acted upon, APA challenges are a potent way to attack the agency and publicly signal disapproval. Litigation over the past five years provides such examples. ${ }^{45}$ Once in litigation, 5 U.S.C. $\S 706$ sleights of hand are an easy way to maintain the offensive, as the petitioners in the DACA case were able to do with the district judge, selling him on "verbal inputs." 456 This profoundly affects the operation of government, inconsistent with the rule of law.

\section{What Should Be Done to Stabilize the Space}

Petitioners and agencies in APA litigation should forcefully and consistently advance the foregoing, proper interpretation of an APA record and how it should be judicially reviewed. Courts, in turn, should follow this proper interpretation. Recognizing the proper scope of the administrative record will facilitate a more efficacious and consistent execution of the APA.

To follow this easier and more proper route, a court should refuse the administrative record as presented only if the petitioner demonstrates, by a standard of at least a "strong showing," that the record is demonstrably incomplete. ${ }^{457}$ The court should also permit the parties to add to the rec-

\footnotetext{
agency action being challenged. For example, the APA is the least specific concerning informal adjudication.

455. See supra note 363 .

456. Statement of Dist. Court in Response to Application for a Stay, No. 17A570 at 4, (Dec. 5, 2017), https://www.supremecourt.gov/DocketPDF/17/17-801/22797/20171206145957950_17A570 \%20In\%20Re\%20United\%20States\%20Response\%20NDCA.pdf [https://perma.cc/A52P-4FBG].

457. Citizens to Pres. Overton Park, Inc. v. Volpe, 401 U.S. 402, 420 (1971) (requiring a "strong showing of bad faith or improper behavior" to permit augmentation of the administrative record in federal court).
} 
ord any materials to which they jointly stipulate, and should take judicial notice where appropriate, like for example, background information necessary to understand complex subject matter. If the court finds that completion or a limited supplementation may occur, the court should consider whether the agency can simply add the concerned materials in federal litigation without engaging in civil discovery. If not, the remedy should then be remand to the agency, with or without vacatur, with or without judicial retention of jurisdiction, for the agency to correct. This should hold whether the problem is properly identified as the record, or whether the issue is that the court "can't tell" if the record is complete or if the agency considered all factors. In other words, courts must be vigilant about not turning merits problems into record problems. This would ensure that courts remain faithful to 5 U.S.C. $\S 706$ 's exhortation to review only "the whole record or those parts of it cited by a party," with consideration of the role of prejudicial error. ${ }^{458}$

Under this correct reading, Overton Park comes out largely the same. Overton Park presented what we would call a completion issue: a set of materials the agency relied upon to make its decision that was not before the court. Because those materials were not presented to the court as part of the administrative record (only post hoc affidavits were), the Court rightly sent the case back down to the district court. However, the district court should have remanded the case to the agency to submit a record, or to reformat its decision and submit that record. The district court should not have taken evidence to decide whether the agency action satisfied the arbitrary-and-capricious standard of the APA. Later Supreme Court cases such as Lorion later seemed to appreciate that difference.

This raises the question of how to encourage judicial compliance with these rules. Chiefly, advocates need to be aware of the proper scope of the record to accurately educate the court. Additionally, the U.S. Supreme Court could step in to articulate clear guidelines. Lower courts are imprecise about the record rule and allow various exceptions that might not rise to the level of a circuit split. But it may be enough if a petition for a writ of certiorari or mandamus shows that there is a policy of

458. Steven Stark \& Sarah Wald, Setting No Records: The Failed Attempts to Limit the Record in Review of Administrative Action, 36 ADMIN L. REV. 333, 359 (1984) (arguing that those doctrines have eroded Overton Park to the point that parties may evade the "whole record" limitation at will. Considering that administrative records are not always contemporaneously compiled, and given the number of completion and supplementation exceptions, "courts may be better off simply scrapping the rule of limited record review in cases reviewing informal agency action. It makes no sense to pay homage to a legal fiction."). That would be even less workable and more burdensome on the agencies and would violate 5 U.S.C. § 706. 
national importance.

The Supreme Court has recently corrected a different longstanding misinterpretation of the APA. In 2015, it reversed a D.C. Circuit line of authority requiring notice-and-comment for non-legislative rulemaking, holding it exceeded the APA's minimum requirements and thus violated Vermont Yankee. ${ }^{459}$ The Supreme Court also granted the writ of mandamus on this subject in In re United States. ${ }^{460}$ Although the Court emphasized that it was not opining on the merits of the APA record issues, the Court arguably took up the case only because the legal dispute arose from an agency action to terminate a program that generated significant news coverage and affected hundreds of thousands of individuals over the program's relatively short lifespan. If the Supreme Court did take up and resolve a case presenting the issues undergirding this Article, it would likely be a watershed administrative law case on par with Overton Park itself. Despite the Court's flirtation with the topic in the In re United States DACA case, after the Court's remand there is no indication that it will again review the case on this topic. Even though the Supreme Court again touched on the topic in the 2018 In re Dep't of Commerce census question case, a merits decision might involve only the "bad faith and improper behavior" exception, and not the record scope in general. ${ }^{461}$ It might very well be another thirty years before the Court broaches the subject again.

The first branch of government, Congress, could also address the problem legislatively, although that is even less likely. Congress could amend the APA to more clearly define "record" or identify what procedures it wishes to use for APA record compilation and review. This would be especially useful with regard to informal adjudication procedures which are not clearly outlined in the APA. However, Congress rarely amends the APA, and has never substantively amended 5 U.S.C. $\S 706$ since it was first passed in $1946 .{ }^{462}$

459. See Perez v. Mortg. Bankers Ass'n, 135 S. Ct. 1199 (2015) (reversing the D.C. Circuit's Paralyzed Veterans doctrine unanimously with three concurrences).

460. In re United States, 138 S. Ct. 443 (2017).

461. In re Dep't of Commerce, No. 18A375, 2018 WL 5259090 (U.S. Oct. 22, 2018).

462. Compare Administrative Procedure Act, Pub. L. 79-404, 79th Cong. Ch. 324, 60 Stat. 237 (1946), with 5 U.S.C. $§ 706$ (2012). Congress did once make slight grammatical and style revisions to 5 U.S.C. $\S 706$, in 1966, but the changes were not material. For example, the 1966 revisions included changing:

"In making the foregoing determinations the court shall review the whole record or such portions thereof as may be cited by any party, and due account shall be taken of the rule of prejudicial error." Pub. L. 89-554, 80 Stat. 393 (1966).

To:

"In making the foregoing determinations, the court shall review the whole record or those parts of it 
From time to time, Congress has introduced bills to amend the Administrative Procedure Act with regard to what makes up the record. For instance, the Regulatory Accountability Act of 2011, House Report 3010, would have amended $\S 553$ to provide special procedures for "major rules, high-impact rules, and rules involving novel legal or policy issues." ${ }^{" 463}$ For judicial review of the procedures of passing such rules, the record on review would generally have included "all documents and information considered by the agency and any additional information presented by a party that the court determines necessary to consider to assure justice." 464 Generally, the agency would have to:

include in the record for a rule making, and shall make available by electronic means and otherwise, all documents and information prepared or considered by the agency during the proceeding, including, at the discretion of the President or the Administrator of the Office of Information and Regulatory Affairs, documents and information communicated by that Office during consultation with the Agency. ${ }^{465}$

Although less desirable than a universal fix from Congress, the agencies could also promulgate regulations to clarify the meaning of the arguably ambiguous phrase "the whole record," although that might vary from agency to agency and lead to greater confusion.

The best option would be to have the courts address the issue in their rulemaking capacities. The Federal Rules of Appellate Procedure already give some treatment to record contents, albeit the record on appeal. ${ }^{466}$ Although the Federal Rules of Civil Procedure have a transsubstantive grain, passing rules for particular subject matter is not new. ${ }^{467}$ Congress and the Supreme Court passed specific rules governing habeas cases and motions for post-conviction relief in the late 1970s. ${ }^{468}$ The Administrative Conference of the United States, an independent government agency that examines administrative law issues, recently called for Congress and the Supreme Court to enact specific rules for Social Secu-

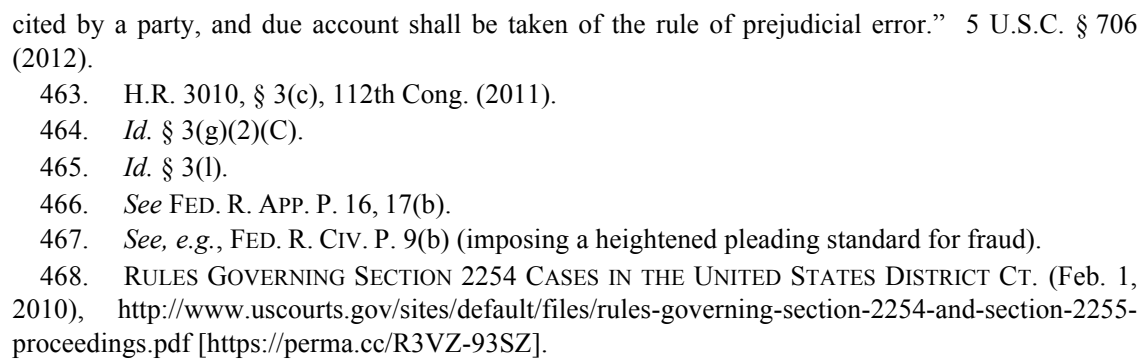


rity benefits appeals. ${ }^{469}$ The Supreme Court could pass these rules without congressional assistance, as the Rules Enabling Act permits the Court to promulgate "general rules of practice and procedure ... for cases in the United States district courts (including proceedings before magistrate judges thereof) and courts of appeals.

Lower courts could also accomplish this, to a degree. Many lower courts have local court rules, consistent with Overton Park, that streamline the process of putting the record in front of the court for judicial review. Most courts rules are procedural. For example, some excuse suits from initial disclosures if review is on the record, ${ }^{471}$ or exempt such suits from a scheduling order. ${ }^{472}$ Some rules are more substantive, making clear that the judicial record is coextensive with the agency record. ${ }^{473}$ The U.S. District Court for the District of Utah, for example, has particularly comprehensive rules, disabling most of the default Federal Rules of Civil Procedure in favor of a simple process of adjudicating APA cases more aligned with their appellate-like nature than a traditional civil case. $^{474}$

Passing rules governing the procedure of APA review cases and using those rules to emphasize the grounds under which the composition of the administrative record may be challenged would discourage the forum-shopping that is now available to enterprising litigants. Such rules would prevent litigants from forcing discovery and delving beyond the administrative record, as they are able to do in certain courts given the federal government's susceptibility to suit in many jurisdictions. This proposal would create many benefits to the taxpayers if their government agencies could have their actions reviewed in accordance with law. ${ }^{475}$

469. Admin. Conf. of the United States, Special Procs. For Social Security Litig. IN DiSTRICT CT. (2016), https:/www.acus.gov/sites/default/files/documents/Recommendation \%202016-3.pdf [https://perma.cc/7QYU-VB4D].

470. 28 U.S.C. $\$ 2072($ a) (2012).

471. FED. R. CIV. P. 26(a)(1)(B)(i).

472. S.D.N.Y. \& E.D.N.Y. CIV. R. 16.1.

473. D. Wyo. CiV. R. 83.6(b)(1). But see id. R. 83.6(b)(3) (permitting "supplementation of the record" in certain limited circumstances, upon motion filed within 14 days after the record is filed).

474. See supra note 347.

475. A recent law review article proposed other solutions. Travis O. Brandon proposed that the parties more carefully hew to a proper taxonomy of the administrative record and extra-record evidence-including by permitting completion. Reforming the Extra-Record Evidence Rule in Arbitrary and Capricious Review of Informal Agency Actions: A New Procedural Approach, 21 LEWIS \& ClARK L. REV. 981, 1007-17 (2017). He also suggested that courts should be more willing to consider extra-evidence if interested parties did not previously have an opportunity to present the evidence to the agency (although his article does not explain how this additional imposition on the agencies to accept evidence comports with Vermont Yankee). Id. at 1017-28. 


\section{CONCLUSION}

What goes into the administrative record reviewed by a court in an APA action is a deceptively simple inquiry: what materials did the agency consider in making the decision being challenged? This topic has gone largely unexplored in literature, as courts - pressed by zealous advocates who chafe at the proper restrictions in APA practice not found in other civil actions - create a myriad of exceptions that seem reasonable. However, the APA's text, history, structure, and purpose carefully delineate the scope of the record, no matter how reasonable it may seem to allow the government or a petitioner to slip a few documents into the record for judicial consideration.

Although the APA's record rule has been in the U.S. Code for over seventy years, the Supreme Court shows no sign of definitely resolving this issue. Nevertheless, the issue is pressing, as an increasing number of heated lawsuits challenge administrative action and seek discovery or the supplementation of the administrative record. Meanwhile, lower courts remain split in their approaches, contributing to uncertainty for massive bureaucracies seeking to implement best practices at minimum costs to the taxpayer.

This Article chronicled why an agency sued under the APA merits the presumption that it is acting in accordance with the law and thus presenting a true and complete copy of the administrative record to the court. The only ground for adding material to that record should come if the petitioner can show that the record is demonstrably incomplete, whether by inadvertence or intent. Additionally, in recognition of the reality that agencies' work can be complex and builds on years of immersion in a particular subject matter, courts should be able to take judicial notice of uncontroversial and readily provable background material. Courts should also defer to the parties if they jointly stipulate to adding material to the record.

Where the courts should draw the line is when a party wishes to avail itself of any number of the amorphous "supplementation" exceptions created over the years. Whatever the reasons a party may give for wanting to add material to the record that the agency did not rely upon when it took the action under review, the court should resist the temptation to allow supplementation and instead conduct a merits inquiry on the record that is available. If the record shows a legal flaw, or if the record is not full enough to permit a proper analysis, then the APA petition should succeed on the merits and the court should set aside the agency action and remand to the agency to address the issue. This allows the agency to 
proceed in due course and possibly resolve the dispute without further Article III intervention. This approach both saves time and money for all involved and respects the separation of powers. Until Congress or the courts prescribe a different regime, the bench and bar would benefit from the simplicity, if not correctness, of this approach. 